\title{
The molecular mechanisms underlying 6-hydroxydopamine and ethanol-induced neurotoxicity
}

\author{
Gang Chen \\ West Virginia University
}

Follow this and additional works at: https://researchrepository.wvu.edu/etd

\section{Recommended Citation}

Chen, Gang, "The molecular mechanisms underlying 6-hydroxydopamine and ethanol-induced neurotoxicity" (2005). Graduate Theses, Dissertations, and Problem Reports. 4140.

https://researchrepository.wvu.edu/etd/4140

This Dissertation is protected by copyright and/or related rights. It has been brought to you by the The Research Repository @ WVU with permission from the rights-holder(s). You are free to use this Dissertation in any way that is permitted by the copyright and related rights legislation that applies to your use. For other uses you must obtain permission from the rights-holder(s) directly, unless additional rights are indicated by a Creative Commons license in the record and/ or on the work itself. This Dissertation has been accepted for inclusion in WVU Graduate Theses, Dissertations, and Problem Reports collection by an authorized administrator of The Research Repository @ WVU.

For more information, please contact researchrepository@mail.wvu.edu. 


\title{
The molecular mechanisms underlying 6-hydroxydopamine and ethanol-induced neurotoxicity
}

\author{
Gang Chen \\ Dissertation submitted to the \\ Davis College of Agriculture, Forestry and Consumer Sciences \\ At West Virginia University \\ In partial fulfillment of the requirements \\ For the degree of \\ Doctor of Philosophy \\ In \\ Genetics and Developmental Biology
}

Jia Luo, Ph.D., Chair

Binghua Jiang, Ph.D.

Daniel G. Panaccione, Ph.D.

Xianglin Shi, Ph.D.

Sharon L. Wenger, Ph.D.

Genetics and Developmental Biology Program

Morgantown, West Virginia

2005

Keywords: Apoptosis, caspases, endoplasmic reticulum stress, neurodegeneration, neurotrophins, Fetal Alcohol Syndrome, protein synthesis

Copyright 2005 Gang Chen 


\title{
Abstract \\ The molecular mechanisms underlying 6-hydroxydopamine and ethanol-induced neurotoxicity
}

\author{
Gang Chen
}

Ethanol and 6-hydroxydopamine (6-OHDA), a Parkinson's disease (PD) mimetic, are two toxins to the cerebellum. This study investigated the molecular mechanisms underlying their neurotoxicities. The work in chapter 2 of this thesis focused on 6OHDA-induced neurodegeneration. Previous studies indicate that impaired function of the endoplasmic reticulum (ER), commonly referred to as ER stress, is an important factor in the neuropathology of a wide variety of neurological disorders. This study demonstrated that 6-OHDA evoked ER-stress and led to apoptosis in SH-SY5Y neuronal cell line and cultured rat cerebellar granule neurons (CGNs). Furthermore, GSK3 $\beta$ played a crucial role in mediating 6-OHDA's neurotoxicity. GSK3 $\beta$ inhibitors and neurotrophic factor, such as BDNF, protected neural cells against 6-OHDA-induced cell death. The results suggest that GSK3 $\beta$ is an important intermediate in proapoptotic signaling cascades that are associated with neurodegenerative disease, thus providing a potential taget site amenable to pharmacological intervention. The work in chapter 3 explored the intracellular signaling pathway that responds to ethanol-induced damage to the cerebellum. Numerous studies have found that early developmental exposure to ethanol caused profound damage to the cerebellum, leading to significant reduction in cerebellum volume, weight and protein content. PACT (Rax) / PKR / eIF2 $\alpha$ is an important signal transducing pathway which controls the protein synthesis initiation response to different stimuli. Previous studies have shown that ethanol exposure decreases the protein content in rat cerebellum and inhibits protein synthesis initiation in rat heart, liver and skeletal muscle. This study demonstrated that the expressions of PACT (Rax) / PKR / eIF2 $\alpha$ are developmentally regulated in rat developing cerebellum; ethanol exposure promotes the association of PACT (Rax) with PKR. Ethanol-induced interaction between PACT(Rax) and PKR leads to phosphorylation of eIF2 $\alpha$ and protein synthesis initiation inhibition. This inhibition can be enhanced by over-expression of PACT (Rax) and reversed by a mutated PACT (Rax) gene at serine 18 or PKR inhibitors. The results provide a novel insight into the molecular mechanism of ethanol toxicity. 


\section{Acknowledgements}

I would like to thank my academic supervisor, Dr. Jia Luo, for his steadfast support throughout this project and throughout my graduate studies. His guidance and friendship have been invaluable and I am very grateful.

I would also like to express my gratitude to members of my dissertation committee, Drs. Jiang, Panaccione, Shi and Wenger, for their time and efforts in reviewing my dissertation.

For their help and friendship, appreciative thanks are extended to past and present members in Dr. Luo's lab, Dr. Ma, Dr. Li, Dr. Aye, Dr. Ayoub, Hong Lin, Kim Brower, Mohammad Odetallah and Mari Nichols-Haining.

Finally, I would like to offer special thanks to my wife, Mei, My son, David, and my parents and parents-in-law. Without their support and love none of this would have been done. 


\section{Table of Contents}

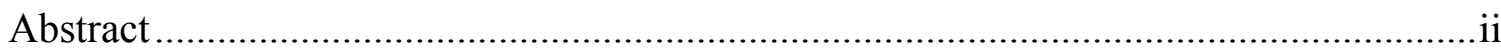

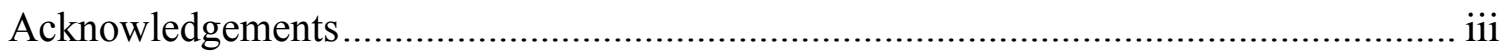

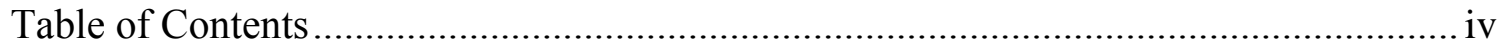

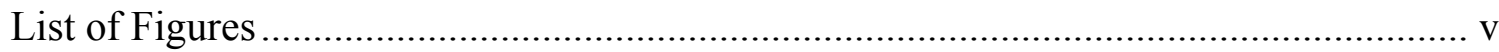

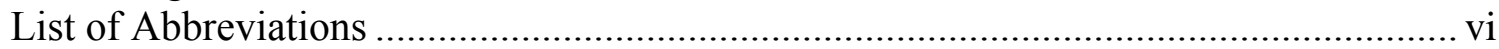

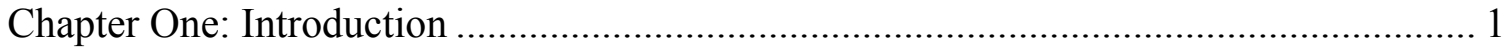

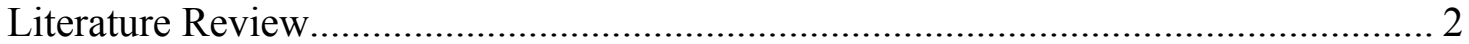

1. 6-Hydroxydopamine, Glycogen Synthase Kinase $3 \beta$ (GSK3 $\beta$ ) and Neuronal

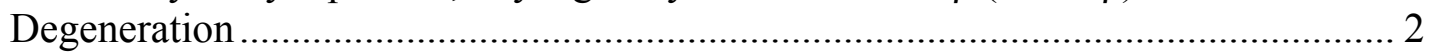

2. Ethanol, PACT/Rax-PKR-eIF2 $\alpha$ and protein synthesis................................. 9

Chapter Two: Glycogen Synthase Kinase $3 \beta$ (GSK3 $\beta$ ) Mediates 6-Hydroxydopamine (6-

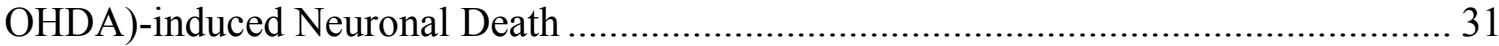

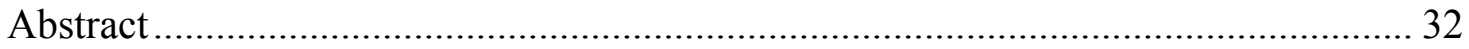

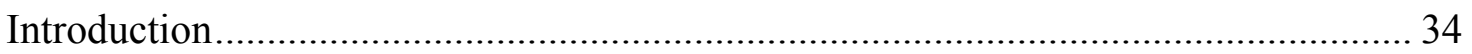

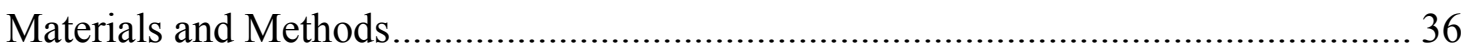

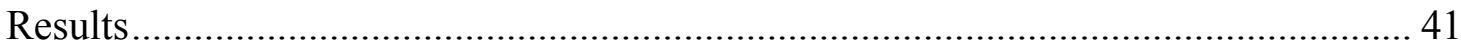

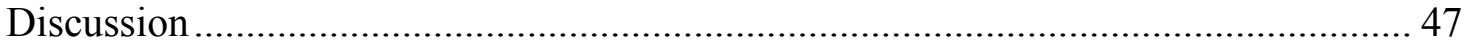

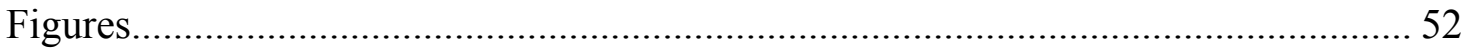

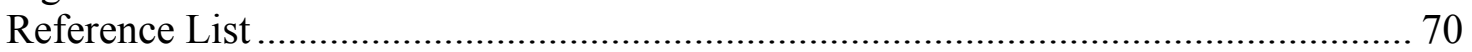

Chapter Three: The Mechanism of Ethanol-induced Protein Synthesis Inhibition in

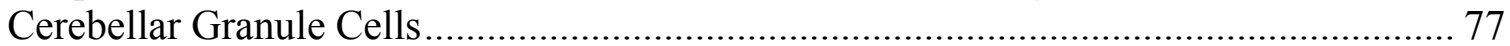

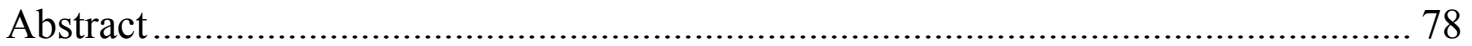

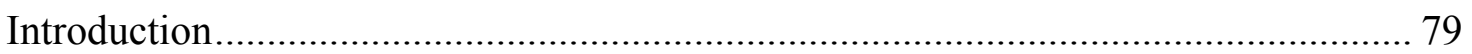

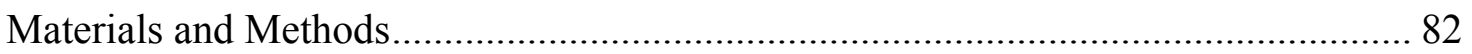

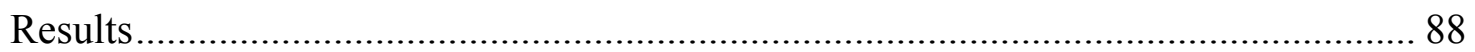

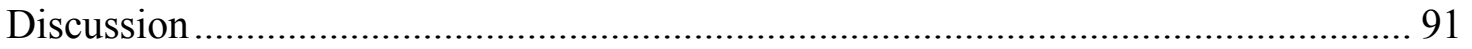

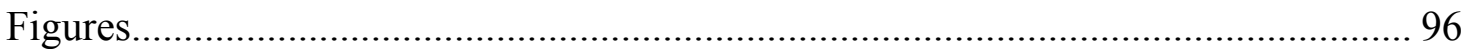

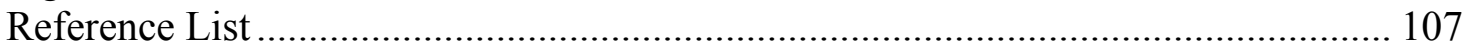

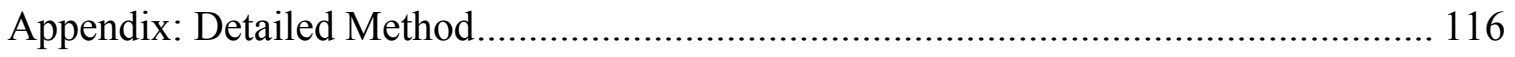

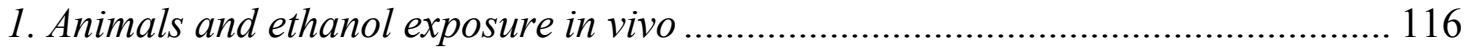

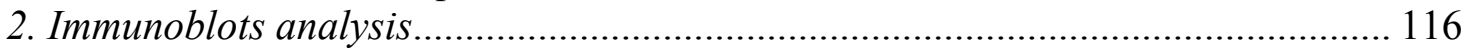

3. Cerebellar granule cell culture and ethanol exposure in vitro............................... 117

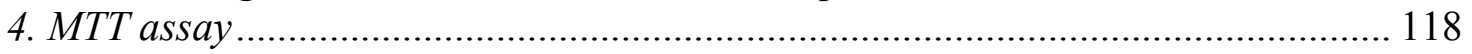

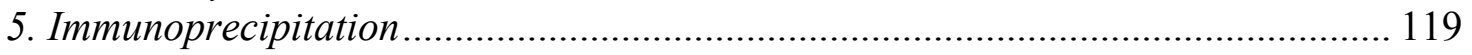

6. Culture of human neuroblastoma cells expressing inducible TrkB ....................... 119

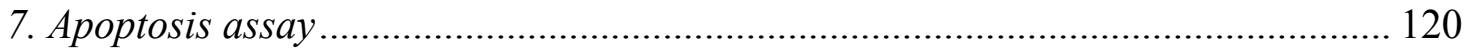

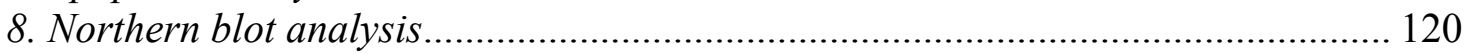

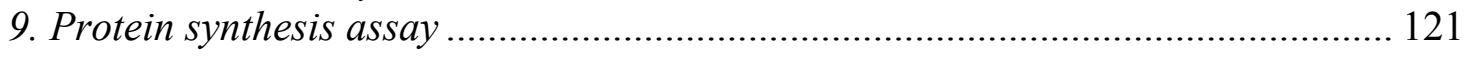

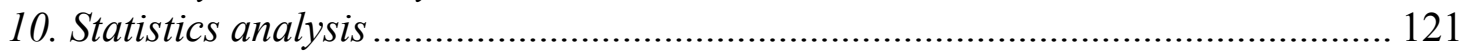

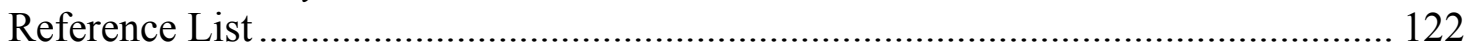

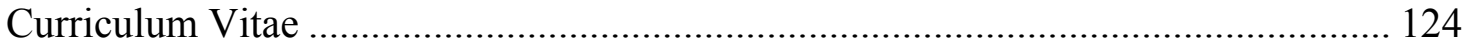




\section{List of Figures}

\section{Chapter Two}

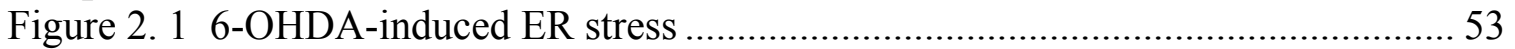

Figure 2. 2 6-OHDA-induced apoptosis of SH-SY5Y cells ........................................ 55

Figure 2. 3 Effect of 6-OHDA on GSK3 $\beta$, Akt and Cyclin D1 .................................... 58

Figure 2. 4 Effect of inhibitor of PP2A/PP1 on 6-OHDA-mediated GSK3 $\beta$

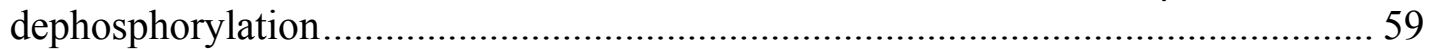

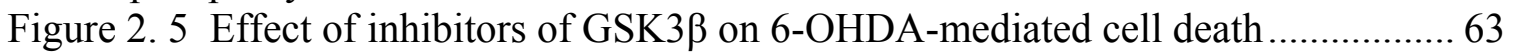

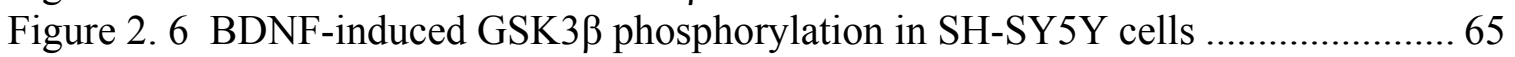

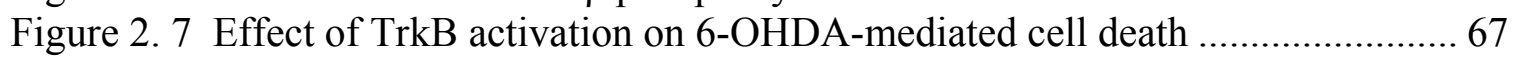

Figure 2. 8 Effect of antioxidants on 6-OHDA-induced cell death and GSK3 $\beta$

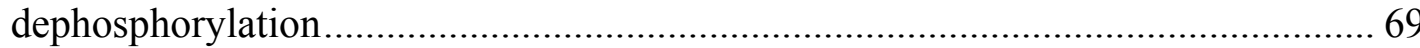

\section{Chapter Three}

Figure 3. 1 Effect of ethanol on PKR and eIF2 $\alpha$ activation 98

Figure 3. 2 Ethanol upregulates phosphorylation of PKR and eIF2 $\alpha$ in rat pup's cerebellum

Figure 3. 3 Effect of PKR inhibitors on ethanol-induced eIF2 $\alpha$ phosphorylation......... 101

Figure 3. 4 Ethanol fails to induce eIF2 $\alpha$ activation in PKR-deficient MEFs............... 102

Figure 3. 5 Effect of ethanol on eIF2 $\alpha$ phophorylation in wildtype and serine 18 mutated

Rax transfected SK-N-MC cells 104

Figure 3. 6 Ethanol promotes the association between PKR and Rax 105

Figure 3. 7 Ethanol-induced protein synthesis inhibition was alleviated in Rax mutated

SK-N-MC cells 106 


\section{List of Abbreviations}

$\begin{array}{ll}\text { AD } & \text { Alzheimer's disease } \\ \text { 2-Ap } & \text { 2-Aminopurine } \\ \text { BDNF } & \text { Brain-derived neurotrophic factor } \\ \text { CGC } & \text { Cerebellar granule cell } \\ \text { CGN } & \text { Cerebellum granule neuron } \\ \text { CHOP } & \text { C/EBP homologus protein } \\ \text { CNS } & \text { Central nervous system } \\ \text { dsRNA } & \text { Double-stranded RNA } \\ \text { eIF2 } \alpha & \alpha \text { subunit of eukaryotic translation initiation factor-2 } \\ \text { ER } & \text { Endoplasmic reticulum } \\ \text { EtOH } & \text { Ethanol } \\ \text { FAS } & \text { Fetal alcohol syndrome } \\ \text { GADD153 } & \text { Growth Arrest and DNA Damage inducible } \\ \text { GD } & \text { Gestational day } \\ \text { GRP78 } & \text { Glucose-regulated protein 78 } \\ \text { GSK3 } \beta & \text { Glycogen synthase kinase-3 } \beta \\ \text { MEF } & \text { Mouse embryonic fibroblasts } \\ \text { MPP } & \text { 1-methyl-4-phenyl-pyridinium } \\ 6-O H D A & \text { 6-Hydroxydopamine } \\ \text { PACT } & \text { PKR-activating protein } \\ \text { PARP } & \text { Poly(ADP-ribose) polymerase } \\ \text { PD } & \text { Parkinson's disease } \\ \text { PDL } & \text { Poly-D-lysine } \\ \text { PKR } & \text { Double-stranded RNA activated protein kinase } \\ \text { PP2A } & \text { Protein phosphatase 2A } \\ \text { ROS } & \text { Reactive oxygen species } \\ & \end{array}$


Chapter One: Introduction 


\section{Literature Review}

\section{6-Hydroxydopamine, Glycogen Synthase Kinase $3 \beta$ (GSK3ß) and Neuronal Degeneration}

\subsection{ER stress and neuronal pathogenesis}

The endoplastic reticulum (ER) is an important intracellular compartment that regulates protein synthesis, protein folding and trafficking, cellular responses to stress, and intracellular calcium $\left(\mathrm{Ca}^{2+}\right)$ levels (1-3). Alterations in $\mathrm{Ca}^{2+}$ homeostasis and accumulation of unfolded proteins in the ER cause ER stress $(4 ; 5)$. A variety of toxic

insults, including $\mathrm{Ca}^{2+}$ ionophores, inhibitors of glycosylation, chemical toxicants, and oxidative stress can all cause ER stress and ultimately lead to cell death (6-14). Although the ER plays an essential role in important cell functions, until recently the possible involvement of the ER dysfunction in neuropathology such as ischemia, epileptic seizures and Alzheimer's or Parkinson's disease has been largely neglected. Much data show that ER function is disturbed in many acute and chronic diseases of the brain, for example: the ER-associated degradation of misfolded proteins is affected in Parkinson's disease, the unfolded protein response is down-regulated in Alzheimer's disease, and the ER calcium homeostasis is disturbed in ischemia (15-23).

Neuronal viability is maintained through a complex interaction network of signaling pathways that can be perturbed in response to a multitude of cellular stresses. A shift in one or more of these pathways can alter the fate of a neuron resulting in cell death or continued survival $(24 ; 25)$. Apoptosis is a mechanism of cell death that plays a fundamental role during the development of many tissues or organs including the central nervous system. Apoptosis has traditionally been distinguished in developing tissues on 
the basis of specific morphological and biochemical criteria, including perinuclear chromatin condensation, cell shrinkage and endonuclease-mediated internucleosomal DNA fragmentation into a ladder pattern. More recently, the term apoptosis has been used to describe the programmed biochemical pathways of cell death that accompany development, tissue injury and degeneration (26;27). Several studies indicated that ER stress was involved in certain types of neuronal apoptosis $(28 ; 29)$; however, the signaltransducting events that connect ER stress to neuronal degeneration are incompletely understood (30-32).

\subsection{ER stress and GRP78}

The ER provides a unique oxidizing environment in which reside numerous protein chaperones that facilitate and promote the productive folding of proteins and protein complexes. These chaperones provide two important functions in protein folding (33-36). First, there are proteins such as protein disulfide isomerase (PDI) and cis-trans prolyl isomerase that catalyze protein-folding reactions and facilitate proteins to attain their final folded conformation. Second, there are protein chaperones that do not directly catalyze protein folding, but rather maintain proteins in a folding-competent state. Glucose-regulated protein (GRP) 78 is an ER chaperone protein whose expression is induced during oxidative stress, chemical toxity, treatment with $\mathrm{Ca}^{2+}$ ionophores and inhibitors of glycosylation. This induction, which is part of the unfolded protein response (UPR), is required to alleviate ER stress, maintain ER function, facilitate protein folding and thus protect cells from toxic insults $(37 ; 38)$. GRP78 is now considered an ER stressspecific inducible family of proteins.

\subsection{ER stress and GADD153}


A hallmark of the ER stress is the induction of ER stress-specific proteins such as GADD153 (Growth Arrest and DNA Damage inducible), also known as CHOP (C/EBP homologus protein) or CHOP10. It is a leucine zipper transcription factor that is present at low levels under normal conditions, but is robustly expressed in response to stress (3942). GADD153 functions as a negative regulator of C/EBP (CCAAT/enhancer-binding protein) transcription factors (43). It was originally identified based on its induction following treatment of cells with growth arresting and DNA damage agents, although induced expression of the gene has also been strongly tied to ER stress $(44 ; 45)$. In response to ER stress, the transcription factor GADD153 is induced at the transcriptional level (46). Several groups have reported that induction of GADD153 correlates with the onset of apoptosis (47-49). It was reported that cell killing in response to toxins that induce ER stress was delayed in embryonic fibroblasts derived from mice lacking the GADD153 gene (50). GADD153 is also regulated at the post-transcriptional level by phosphorylation. When phosphorylated on serine residues 78 and 81 by p38 MAP kinase, the transcriptional activation by GADD153 increases (51;52). Most evidence support that GADD153 negatively regulates cell growth and may induce apoptosis (53-55). However, the relationship between expression of GADD153 and cell death is still not very clear $(56 ; 57)$.

\subsection{ER stress and caspase 12}

Caspase stands for cysteine-dependent aspartate specific protease. All caspases are synthesized as inactive proenzymes and activated by proteolytic cleavage (58). Caspases have been divided into several distinct groups based on protein structure and putative functions (27). Caspase 12 in neurons, and other cells, is primarily associated 
with the ER (59-62). Activation of caspase 12 from pro-caspase 12 is specifically induced by ER stress (63). Apoptosis triggered through pathways that do not involve the ER, such as serum deprivation or Fas activation, does not result in activation of caspase 12 (64-66). One of the properties of caspases is transactivation. Once initiator caspases are activated, they can proteolytically process executioner caspases (caspase 3,6 and 7) into their active form (27). Although cytochrome c released from mitochondria has been believed to be required for caspase 9 activation during apoptosis $(67 ; 68)$, it was shown that caspase 12 can activate pro-caspase 9 . The activated caspase 9 then activated caspase 3 through a cytochrome C-independent pathway (69). Caspase 3 is one of the key executioners of apoptosis. During the execution phase of apoptosis, caspase 3 is responsible either partially or totally for the proteolytic cleavage of many key substrates, such as PARP (70). Caspase 3 is activated in the CNS in response to a variety of injurious stimuli including ischemia, exctotoxic insult, neurodegenerative disease and ER stress (71-77).

\subsection{ER stress and PERK/eIF2 $\alpha$}

To survive and adapt under ER stress conditions, cells have a self-protective mechanism against ER stress which has been termed the ER stress response (78;79). There are four functionally distinct responses: First, cells upregulate the genes encoding ER chaperone proteins to increase protein-folding activity and to prevent protein aggregation. Second, the protein synthesis will be attenuated to reduce the load of new protein and to prevent further accumulation of unfolded proteins. Third, misfolded proteins will be degradated in the ER, and Fourth, cells undergo apoptotic death when functions of the ER are extensively impaired (80-82). To attenuate translation, this phenomenon occurs at the level of translational initiation via eIF2 $\alpha$ phosphorylation (83- 
86). The factor eIF $2 \alpha$ mediates the binding of the initiator Met-tRNA to the ribosome. Phosphorylation of eIF $2 \alpha$ at Ser51 blocks this step and protein synthesis is inhibited. This induces cell apoptosis $(85 ; 87-90)$. PERK is an eIF2 $\alpha$ kinase that is localized to the ER and responsible for phosphorylation of eIF2 $\alpha$ during ER stress (91;92). Activation of PERK is triggered by the dissociation of GRP78 from its ER luminal domain as a consequence of ER stress. This leads to oligomerization and trans-autophosphorylation of PERK (93;94).

\subsection{PI3K, GSK-3ß and apoptosis}

Phosphatidylinositol-3 kinase (PI3K) is one of the most important regulatory proteins that is involved in different signaling pathways and controlling of key functions of the cell. Experiments with the use of some specific inhibitors of PI3K or cell transfection with different PI3K gene variants reveal PI3K being a mediator in the control of at least two very important cell functions, namely, cell division (as a necessary component of the signaling pathway initiated by growth factors) and apoptosis (the progress of which is inhibited by PI3K) (95-99). The protein kinase Akt, which was first identified in the AKT virus, has been identified as a key downstream effector of PI3K in signaling cell survival (100-102). Neurotrophic factors such as NGF, BDNF and GDNF activate the PI3-Akt signaling cascade through corresponding receptor tyrosine kinases such as the high affinity neurotrophins receptors (Trks) (103). After receptor dimerization, $\mathrm{PI} 3 \mathrm{~K}$ is recruited to the plasma membrane where its catalytic subunit generates lipid second messengers, phosphoinositide phosphates $\left(\mathrm{PIP}_{2}, \mathrm{PIP}_{3}\right)$ at the inner surface of the plasma membrane. Phosphoinositide-dependent protein kinase-1 (PDK-1) then acts in concert with $\mathrm{PIP}_{2}$ and $\mathrm{PIP}_{3}$ to phosphorylate and activate Akt (104). One of 
the physiological targets of Akt is glycogen synthesis kinase-3 (GSK-3), which is inhibited by phosphorylation (105). There are two highly homologous forms of GSK-3 in mammals, GSK- $3 \alpha$ and GSK-3 $\beta$. GSK- $3 \beta$ is particularly abundant in the central nervous system where it is neuron specific (106). It has been confirmed that GSK-3 signaling has been implicated in neurodegeneration and neuronal apoptosis (107). GSK-3 is unusual in that it appears to be largely regulated by inhibition. One means by which GSK-3 can be inactivated is through phosphorylation of Ser9 in GSK-3 $\beta$ or Ser21 in the case of GSK$3 \alpha$ (108). GSK-3 $\beta$ is also capable of being regulated by an activation pathway. Activation of GSK-3 $\beta$ can be accomplished by phosphorylation at Tyr216 (Tyr 279 for GSK-3 $\alpha$ ). Several cellular stresses including serum deprivation stimulate GSK-3 $\beta$ activity in cortical neurons prior to the induction of apoptosis (109). Inhibition of PI3K induced a

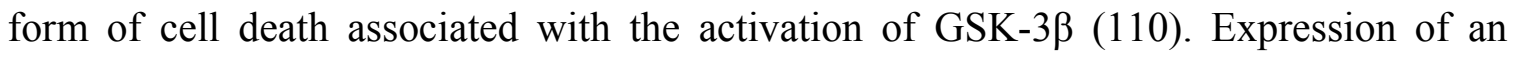

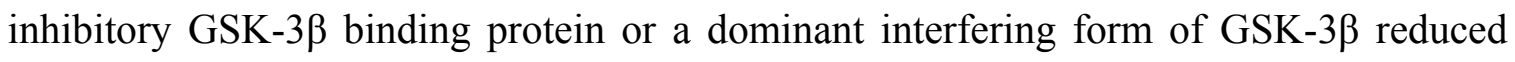
neuronal apoptosis; overexpression of GSK-3 $\beta$ in neurons was sufficient to trigger neuronal cell death $(105 ; 111 ; 112)$. GSK-3 $\beta$ is also a central compartment of the Wnt signaling pathway important for proper axis formation during embryonic development (113) and regulates cyclin D1 proteolysis and subcellular localization (114). However, the detail of this pathway that connects GSK-3 $\beta$ to apoptosis is still not clear.

\subsection{The chemicals and their functions:}

1.6.1. 6-Hydroxydopamine (6-OHDA): This is a selective catecholaminergic neurotoxin widely used to investigate the pathogenesis and progression of Parkinson's disease (PD). The specificity of 6-OHDA neurotoxicity has been associated with its uptake and accumulation by a transport mechanism specific 
for catecholaminergic neurons (115). It has been demonstrated that intrastriatal injection of 6-OHDA is a useful model for studying neuroprotective and neurotrophic therapies for PD (116). In this case, 6OHDA selectively eliminates the dopaminergic axons and terminals within a circumscribed area surrounding the injection site, which is followed by a degeneration of the parent nigral neurons. 6-OHDA has also been proposed as a putative neurotoxic factor in the pathogenesis of PD (105). This suggestion is based on the occurrence of 6-OHDA in both human brain (117) and urine of parkinsonian patients (118). Under physiological conditions 6-OHDA rapidly and nonenzymatically oxidized by molecular oxygen to form hydrogen peroxide $\left(\mathrm{H}_{2} \mathrm{O}_{2}\right)$ and the corresponding p-quinone (119). Although the precise molecular mechanism of cytotoxicity for 6-OHDA remains uncertain, it has been often linked to the production of reactive oxygen species (ROS) $(120 ; 121)$.

1.6.2. Thapsigargin is an effective inhibitor of the $\mathrm{Ca}^{2+}$ ion pump proteins of intracellular membrane located in sarcoplasmic reticulum (SR) and endoplasmic reticulum (ER) of skeletal, cardiac, muscle and brain microsomes (122;123). It interacts strongly with the $\mathrm{SR}$ of $\mathrm{Ca}^{2+}$-transport ATPase. The proposed mechanism of inhibition of $\mathrm{Ca}^{2+}$-ATPase activity including the inhibition of $\mathrm{Ca}^{2+}$ ion binding and enzyme phosphorylation have been reported (124-126). We use it as an inducer of ER stress.

1.6.3. Tunicamycin: Tunicamycin is a mixture of homologous antibiotics which contain uracil, $\mathrm{N}$-acetyl glycosamine, an 11-carbon aminodialdose called 
tunicamine and a fatty acid linked to the amino group. It is an inhibitor of bacterial and eukaryote $\mathrm{N}$-acetylglucosamine transferases; preventing formation of $\mathrm{N}$-acetylglucosamine lipid intermediates and glycosylation of newly synthesized glycoproteins. Tunicamycin blocks the formation of protein $\mathrm{N}$-glycosidic linkages by inhibiting the transfer of $\mathrm{N}$ acetylglycosamine 1-phosphate to dilichol monophosphate (127).

1.6.4. GSK-3 $\beta$ inhibitor (TDZD-8): TDZD-8 (4-Benzyl-2-methyl-1,2,4,thiadiazoline-3,5-dione) is a thiadiazolidinone (TDZD) analog that acts as highly selective, non-ATP competitive inhibitor of GSK-3 $\beta$ by binding to the active site of GSK-3 $\beta$. The molecular mechanism for this is still unknown (128).

1.6.5. Lithium chloride ( $\mathrm{LiCl})$ : $\mathrm{LiCl}$ acts as a direct uncompetitive inhibitor of

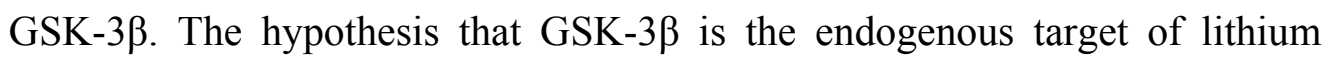
action is supported by the genetic data as well as in vivo biochemical data and while the mechanism remains unknown (129).

\section{Ethanol, PACT/Rax-PKR-eIF2 $\alpha$ and protein synthesis}

\subsection{Fetal Alcohol Syndrome and cerebellar dysfunction}

Alcohol has been widely recognized as a neuroteratogen (130) and maternal alcohol consumption during pregnancy can lead to central nervous system dysfunction in the new born known as the Fetal Alcohol Syndrome (FAS) (131;132), characterized by microcephaly, cognitive impairment, growth deficiency, a pattern of distinct facial features and central nervous system (CNS) disorders $(133 ; 134)$. FAS is considered the 
most common nonhereditary cause of mental retardation (135). It was reported that there were 12,000 new cases of FAS yearly in 1999 in the US (132). The economic costs of alcohol abuse were estimated to have been $\$ 184.6$ billion in 1998 among which FASrelated economic costs were at least $\$ 4.15$ billion (136). Although only $10-40 \%$ of infants of alcohol consumption women meet the criteria of full syndrome, more of them lack the characteristic facial defects and growth deficiency of FAS but still have alcohol-induced mental impairments, refer to as alcohol-related neurodevelopmental disorder (ARND) (135;137-139).

The cerebellum is recognized for its functions in planning and coordinating movement, motor learning and plasticity, and maintaining balance (140). The cerebellum constitutes only $10 \%$ of the total volume of the brain but contains more than half of all its neurons (141). The cerebellum disorders induced by ethanol are common both in humans (142) and animals (143-146). There are two conspicuous neuronal populations in the cerebellum that differ both in size and the timing of their neurogenesis. The population of large Purkinje cells is generated exclusively prenatally in the rat, between gestational days 13 and 16 (147-149). A large population of small granule cells is formed almost exclusively postnatally during the first three weeks after birth (150). Alcohol exposure during the early postnatal period in the rat corresponds to exposure of the human fetus during part of the third trimester called the trimester equivalent $(151 ; 152)$. The developing cerebellum is one of the most vulnerable regions to ethanol both in human and in animals. Numerous animal model systems have been used to characterize FAS and ARND. One of these studies showed that in the growth of the rat brain but not the body was decreased, with cerebellum growth being inhibited twice as much compared with the 
rest of the brain by exposure to ethanol (153). Other studies also showed that the ethanol exposure in rat pups lead to significant reduction in cerebellum volume, weight (154) and protein content (155). However the molecular mechanism(s) involved in ethanol-induced decrease in cerebellum size and inhibition of protein synthesis has not been elucidated.

\subsection{PACT/Rax, PKR, eIF2 $\alpha$ and protein synthesis}

The double-stranded RNA-activated protein kinase (PKR) is a 551 (515 in mouse) amino acid serine/threonine protein kinase ubiquitously expressed in mammalian cells $(156 ; 157)$. PKR consists of two functionally distinct domains: an N-terminal dsRNA binding regulatory domain and the C-terminal catalytic domain. PKR is initially identified as transcriptionally induced by interferon and activated in virus-infected cells by double-stranded RNA (dsRNA) produced during the virus life cycle $(158 ; 159)$. It has been demonstrated that PKR is a component of signal transduction pathways mediating cell growth control, and response to stress (160). PKR can be activated by dsRNA, cytokines (161) and cell stresses such as growth factor or serum deprivation, bacterial products and physiochemical stress $(162 ; 163)$. A pair of dsRNA binding motifs located in the N-terminal domain of PKR act as a sensor to bind dsRNA or protein activators (which themselves contain dsRNA binding domains) (164). The known protein activators include PACT (PKR-activating protein) (165-167) and its mouse homologue RAX (168). PACT/Rax is also a ubiquitously expressed mammalian protein, which will be phosphorylated at serine 18 following stress, heterodimerizes with PKR and activates it in absence of dsRNA (169). Serine 18 of PACT/Rax is a crucial phosphorylation site for activation of PKR. The serine 18 mutated PACT/Rax can still associate with PKR, but has lost its kinase activity (170). Following binding, there is a conformational change in 
PKR, which results in dimerization and autophosphorylation at Thr-446 and Thr451(171-178). Upon activation, PKR will phosphorylate its down stream substrates and the main cellular target of PKR phosphorylation is the $\alpha$-subunit of eukaryotic translation initiation factor-2 (eIF2 $\alpha)(179-181)$. Besides being positively regulated by ds-RNA and PACT/Rax, PKR can be negatively regulated by its cellular inhibitor, P58, a member of the tetratricopeptide (TPR) family of proteins (182). P58 is activated upon influenza virus infection (183) and capable of inhibiting PKR activation and eIF-2 $\alpha$ phosphorylation by direct interaction with PKR and blocking PKR's dimerization (184).

The eIF2 is a three-subunit protein composed of $\alpha$-, $\beta$ - and $\gamma$-subunits with different molecular masses and is required in the first step of initiation of protein synthesis (185). The function of eIF2 $\alpha$ is to mediate the binding of the initiator tRNA, Met-tRNAi, to the 40S-ribosomal subunit as a complex in a GTP-dependent manner (186). Upon joining to the 60S ribosomal subunit, GTP is hydrolyzed and eIF2 is released as eIF2-GDP. Prior to joining Met-tRNAi for another round of initiation, the GDP in eIF2 must be exchanged for GTP. This guanine nucleotide exchange (GNE) reaction is catalyzed by eIF2B $(187 ; 188)$. When PKR phosphorylates eIF2 $\alpha$ at serine- 51 , it converts eIF2 from a substrate to an inhibitor of its guanine nucleotide exchange factor, eIF2B (189). This reduction in recycling of eIF2 by eIF2B leads to inhibition of translation initiation (190). Phosphorylation of the $x_{n}$-subunit in eIF2 occurs in cells or in cell-free translational systems in response to various stimuli, such as ethanol (191), hemedeficiency, viral infection or low levels of double-stranded RNA, amino acid and nutrient starvation, purine limitation, serum and growth factor deprivation, transient transfection of certain plasmids, cerebral ischemia, exercise, heat shock, heavy metals, and release of 
calcium from the endoplasmic reticulum (ER) or ER-stress (192). Several eIF2 $\alpha$ kinases have been reported and each of them reponds to different stimuli. These include hemeregulated kinase (HRI) activated by hemin depriviation (193), double-stranded RNAinduced protein kinase (PKR) by ds-RNAnd PACT/Rax (194), GCN2 kinase from yeast (195), Drosophila and mouse $(196 ; 197)$ by amino acids and sereum starvation, and PKRlike ER kinase (PERK) by ER-stress (198). All these kinases can lead to eIF2 $\alpha$ phophorylation and translation initiation inhibition (199).

\subsection{Ethanol and protein synthesis}

Protein synthesis is essential to sustain normal cellular functions. Previous studies have shown that ethanol significantly impairs brain growth (200), by decreasing the volume, weight and protein content in cerebellum of ethanol-exposed pups (201-203). Ethanol feeding decreased the rate of protein synthesis in rats' heart (204), liver (205) and skeletal muscle (206) by inhibiting peptide-chain initiation. Meanwhile, Wu (207) found that the protein synthesis inhibition induced by ethanol treatment can be partially reversed by adding purified eIF2 (included $\alpha, \beta$ and $\gamma$ subunits) in rabbit reticulocytes. The phosphorylation of eIF $2 \alpha$ can be increased up to $90 \%$ in rat hepatic cells after ethanol feeding (208). Furthermore, the reduction in protein synthesis induced by ethanol occurs through inhibition of protein synthesis initiation by blocking the ternary complex formation among eIF2 $\alpha$, GTP and initiator Met-tRNA rather than alteration in abundance

of aminoacids or ribosomes (209). However no previous work has been done in the neuronal cells to elucidate whether eIF2 $\alpha$ is involved in the mechanism of ethanolinduced protein synthesis inhibition or the signaling pathway that leads to ethanolinduced protein synthesis inhibition. 


\section{Reference List}

1. Berridge, M. J. (1995) Capacitative calcium entry. Biochem.J. 312 ( Pt 1), 1-11

2. Rapoport, T. A. (1992) Transport of proteins across the endoplasmic reticulum membrane. Science 258, 931-936

3. Sambrook, J. F. (1990) The involvement of calcium in transport of secretory proteins from the endoplasmic reticulum. Cell 61, 197-199

4. Kaufman, R. J. (1999) Stress signaling from the lumen of the endoplasmic reticulum: coordination of gene transcriptional and translational controls. Genes Dev. 13, 1211-1233

5. Lee, A. S. (1992) Mammalian stress response: induction of the glucose-regulated protein family. Curr.Opin.Cell Biol. 4, 267-273

6. Chatterjee, S., Cheng, M. F., Berger, S. J., Berger, N. A. (1994) Induction of M(r) 78,000 glucose-regulated stress protein in poly(adenosine diphosphate-ribose) polymerase- and nicotinamide adenine dinucleotide-deficient V79 cell lines and its relation to resistance to the topoisomerase II inhibitor etoposide. Cancer Res. $54,4405-4411$

7. Guo, H., Tittle, T. V., Allen, H., Maziarz, R. T. (1998) Brefeldin A-mediated apoptosis requires the activation of caspases and is inhibited by Bcl-2. Exp.Cell Res. 245, 57-68

8. Yu, Z., Luo, H., Fu, W., Mattson, M. P. (1999) The endoplasmic reticulum stressresponsive protein GRP78 protects neurons against excitotoxicity and apoptosis: suppression of oxidative stress and stabilization of calcium homeostasis. Exp.Neurol. 155, 302-314

9. Shao, R. G., Shimizu, T., Pommier, Y. (1996) Brefeldin A is a potent inducer of apoptosis in human cancer cells independently of p53. Exp.Cell Res. 227, 190-196

10. Perez-Sala, D., Mollinedo, F. (1995) Inhibition of N-linked glycosylation induces early apoptosis in human promyelocytic HL-60 cells. J.Cell Physiol 163, 523-531

11. McCormick, T. S., McColl, K. S., Distelhorst, C. W. (1997) Mouse lymphoma cells destined to undergo apoptosis in response to thapsigargin treatment fail to generate a calcium-mediated grp78/grp94 stress response. J.Biol.Chem. 272, 6087-6092

12. Liu, H., Miller, E., van de, W. B., Stevens, J. L. (1998) Endoplasmic reticulum stress proteins block oxidant-induced $\mathrm{Ca} 2+$ increases and cell death. J.Biol.Chem. $273,12858-12862$ 
13. Li, L. J., Li, X., Ferrario, A., Rucker, N., Liu, E. S., Wong, S., Gomer, C. J., Lee, A. S. (1992) Establishment of a Chinese hamster ovary cell line that expresses grp78 antisense transcripts and suppresses A23187 induction of both GRP78 and GRP94. J.Cell Physiol 153, 575-582

14. Lee, J., Bruce-Keller, A. J., Kruman, Y., Chan, S. L., Mattson, M. P. (1999) 2Deoxy-D-glucose protects hippocampal neurons against excitotoxic and oxidative injury: evidence for the involvement of stress proteins. J.Neurosci.Res. 57, 48-61

15. Paschen, W., Frandsen, A. (2001) Endoplasmic reticulum dysfunction--a common denominator for cell injury in acute and degenerative diseases of the brain? J.Neurochem. 79, 719-725

16. Takahashi, R., Imai, Y., Hattori, N., Mizuno, Y. (2003) Parkin and endoplasmic reticulum stress. Ann.N.Y.Acad.Sci. 991, 101-106

17. Ryu, E. J., Harding, H. P., Angelastro, J. M., Vitolo, O. V., Ron, D., Greene, L. A. (2002) Endoplasmic reticulum stress and the unfolded protein response in cellular models of Parkinson's disease. J.Neurosci. 22, 10690-10698

18. Maguire-Zeiss, K. A., Federoff, H. J. (2003) Convergent pathobiologic model of Parkinson's disease. Ann.N.Y.Acad.Sci. 991, 152-166

19. Lim, K. L., Dawson, V. L., Dawson, T. M. (2003) The cast of molecular characters in Parkinson's disease: felons, conspirators, and suspects. Ann.N.Y.Acad.Sci. 991, 80-92

20. Fahn, S. (2003) Description of Parkinson's disease as a clinical syndrome. Ann.N.Y.Acad.Sci. 991, 1-14

21. Dev, K. K., van der, P. H., Sommer, B., Rovelli, G. (2003) Part I: parkinassociated proteins and Parkinson's disease. Neuropharmacology 45, 1-13

22. Hardy, J. (2003) The relationship between Lewy body disease, Parkinson's disease, and Alzheimer's disease. Ann.N.Y.Acad.Sci. 991, 167-170

23. Heidenreich, K. A. (2003) Molecular mechanisms of neuronal cell death. Ann.N.Y.Acad.Sci. 991, 237-250

24. Walczak, H., Krammer, P. H. (2000) The CD95 (APO-1/Fas) and the TRAIL (APO-2L) apoptosis systems. Exp.Cell Res. 256, 58-66

25. Miller, T. M., Moulder, K. L., Knudson, C. M., Creedon, D. J., Deshmukh, M., Korsmeyer, S. J., Johnson, E. M., Jr. (1997) Bax deletion further orders the cell death pathway in cerebellar granule cells and suggests a caspase-independent pathway to cell death. J.Cell Biol. 139, 205-217 
26. Jansen-Durr, P. (2002) Cell death and aging--a question of cell type.

ScientificWorldJournal. 2, 943-948

27. Morrison, R. S., Kinoshita, Y., Johnson, M. D., Ghatan, S., Ho, J. T., Garden, G. (2002) Neuronal survival and cell death signaling pathways. Adv.Exp.Med.Biol. $513,41-86$

28. Mattson, M. P., LaFerla, F. M., Chan, S. L., Leissring, M. A., Shepel, P. N., Geiger, J. D. (2000) Calcium signaling in the ER: its role in neuronal plasticity and neurodegenerative disorders. Trends Neurosci. 23, 222-229

29. Sherman, M. Y., Goldberg, A. L. (2001) Cellular defenses against unfolded proteins: a cell biologist thinks about neurodegenerative diseases. Neuron 29, 15 32

30. Paschen, W., Doutheil, J. (1999) Disturbance of endoplasmic reticulum functions: a key mechanism underlying cell damage? Acta Neurochir.Suppl 73, 1-5

31. Chen, L., Gao, X. (2002) Neuronal apoptosis induced by endoplasmic reticulum stress. Neurochem.Res. 27, 891-898

32. Rao, R. V., Hermel, E., Castro-Obregon, S., del, R. G., Ellerby, L. M., Ellerby, H. M., Bredesen, D. E. (2001) Coupling endoplasmic reticulum stress to the cell death program. Mechanism of caspase activation. J.Biol.Chem. 276, 33869-33874

33. Gething, M. J., Sambrook, J. (1992) Protein folding in the cell. Nature 355, 33-45

34. Hayashi, T., Saito, A., Okuno, S., Ferrand-Drake, M., Chan, P. H. (2003) Induction of GRP78 by ischemic preconditioning reduces endoplasmic reticulum stress and prevents delayed neuronal cell death. J.Cereb.Blood Flow Metab 23, 949-961

35. Jorgensen, M. M., Bross, P., Gregersen, N. (2003) Protein quality control in the endoplasmic reticulum. APMIS Suppl 86-91

36. Reddy, R. K., Mao, C., Baumeister, P., Austin, R. C., Kaufman, R. J., Lee, A. S. (2003) Endoplasmic reticulum chaperone protein GRP78 protects cells from apoptosis induced by topoisomerase inhibitors: role of ATP binding site in suppression of caspase-7 activation. J.Biol.Chem. 278, 20915-20924

37. Welihinda, A. A., Tirasophon, W., Kaufman, R. J. (1999) The cellular response to protein misfolding in the endoplasmic reticulum. Gene Expr. 7, 293-300

38. Lievremont, J. P., Rizzuto, R., Hendershot, L., Meldolesi, J. (1997) BiP, a major chaperone protein of the endoplasmic reticulum lumen, plays a direct and important role in the storage of the rapidly exchanging pool of $\mathrm{Ca} 2+$.

J.Biol.Chem. 272, 30873-30879 
39. Carlson, S. G., Fawcett, T. W., Bartlett, J. D., Bernier, M., Holbrook, N. J. (1993) Regulation of the C/EBP-related gene gadd153 by glucose deprivation. Mol.Cell Biol. 13, 4736-4744

40. Fornace, A. J., Jr., Nebert, D. W., Hollander, M. C., Luethy, J. D., Papathanasiou, M., Fargnoli, J., Holbrook, N. J. (1989) Mammalian genes coordinately regulated by growth arrest signals and DNA-damaging agents. Mol.Cell Biol. 9, 4196-4203

41. Wang, X. Z., Lawson, B., Brewer, J. W., Zinszner, H., Sanjay, A., Mi, L. J., Boorstein, R., Kreibich, G., Hendershot, L. M., Ron, D. (1996) Signals from the stressed endoplasmic reticulum induce $\mathrm{C} / \mathrm{EBP}$-homologous protein (CHOP/GADD153). Mol.Cell Biol. 16, 4273-4280

42. Lluis, J. M., Colell, A., Garcia-Ruiz, C., Kaplowitz, N., Fernandez-Checa, J. C. (2003) Acetaldehyde impairs mitochondrial glutathione transport in HepG2 cells through endoplasmic reticulum stress. Gastroenterology 124, 708-724

43. Sylvester, S. L., ap Rhys, C. M., Luethy-Martindale, J. D., Holbrook, N. J. (1994) Induction of GADD153, a CCAAT/enhancer-binding protein (C/EBP)-related gene, during the acute phase response in rats. Evidence for the involvement of C/EBPs in regulating its expression. J.Biol.Chem. 269, 20119-20125

44. Fontanier-Razzaq, N. C., Hay, S. M., Rees, W. D. (1999) Upregulation of CHOP10 (gadd153) expression in the mouse blastocyst as a response to stress. Mol.Reprod.Dev. 54, 326-332

45. McCullough, K. D., Martindale, J. L., Klotz, L. O., Aw, T. Y., Holbrook, N. J. (2001) Gadd153 sensitizes cells to endoplasmic reticulum stress by downregulating Bcl2 and perturbing the cellular redox state. Mol.Cell Biol. 21, 12491259

46. Bernstein, H., Payne, C. M., Bernstein, C., Schneider, J., Beard, S. E., Crowley, C. L. (1999) Activation of the promoters of genes associated with DNA damage, oxidative stress, ER stress and protein malfolding by the bile salt, deoxycholate. Toxicol.Lett. 108, 37-46

47. Eymin, B., Dubrez, L., Allouche, M., Solary, E. (1997) Increased gadd153 messenger RNA level is associated with apoptosis in human leukemic cells treated with etoposide. Cancer Res. 57, 686-695

48. Friedman, A. D. (1996) Hematologic manifestations of viral infections. Pediatr.Ann. 25, 555-560

49. Matsumoto, M., Minami, M., Takeda, K., Sakao, Y., Akira, S. (1996) Ectopic expression of CHOP (GADD153) induces apoptosis in M1 myeloblastic leukemia cells. FEBS Lett. 395, 143-147 
50. Zinszner, H., Kuroda, M., Wang, X., Batchvarova, N., Lightfoot, R. T., Remotti, H., Stevens, J. L., Ron, D. (1998) CHOP is implicated in programmed cell death in response to impaired function of the endoplasmic reticulum. Genes Dev. 12, 982-995

51. Wang, X. Z., Ron, D. (1996) Stress-induced phosphorylation and activation of the transcription factor CHOP (GADD153) by p38 MAP Kinase. Science 272, 13471349

52. Ubeda, M., Wang, X. Z., Zinszner, H., Wu, I., Habener, J. F., Ron, D. (1996) Stress-induced binding of the transcriptional factor CHOP to a novel DNA control element. Mol.Cell Biol. 16, 1479-1489

53. Lovat, P. E., Oliverio, S., Corazzari, M., Ranalli, M., Pearson, A. D., Melino, G., Piacentini, M., Redfern, C. P. (2003) Induction of GADD153 and Bak: novel molecular targets of fenretinide-induced apoptosis of neuroblastoma. Cancer Lett. $197,157-163$

54. Ubeda, M., Habener, J. F. (2003) CHOP transcription factor phosphorylation by casein kinase 2 inhibits transcriptional activation. J.Biol.Chem. 278, 40514-40520

55. Lengwehasatit, I., Dickson, A. J. (2002) Analysis of the role of GADD153 in the control of apoptosis in NS0 myeloma cells. Biotechnol.Bioeng. 80, 719-730

56. McCullough, K. D., Martindale, J. L., Klotz, L. O., Aw, T. Y., Holbrook, N. J. (2001) Gadd153 sensitizes cells to endoplasmic reticulum stress by downregulating Bcl2 and perturbing the cellular redox state. Mol.Cell Biol. 21, 12491259

57. You, K. R., Liu, M. J., Han, X. J., Lee, Z. W., Kim, D. G. (2003) Transcriptional regulation of the human transferrin gene by GADD153 in hepatoma cells. Hepatology 38, 745-755

58. Taylor, J., Ikeda, M. (2000) Role of caspases in neuronal damage. Drug News Perspect. 13, 5-11

59. Nakagawa, T., Zhu, H., Morishima, N., Li, E., Xu, J., Yankner, B. A., Yuan, J. (2000) Caspase-12 mediates endoplasmic-reticulum-specific apoptosis and cytotoxicity by amyloid-beta. Nature $403,98-103$

60. Nakagawa, T., Yuan, J. (2000) Cross-talk between two cysteine protease families. Activation of caspase-12 by calpain in apoptosis. J.Cell Biol. 150, 887-894

61. Yoneda, T., Imaizumi, K., Oono, K., Yui, D., Gomi, F., Katayama, T., Tohyama, M. (2001) Activation of caspase-12, an endoplastic reticulum (ER) resident caspase, through tumor necrosis factor receptor-associated factor 2-dependent mechanism in response to the ER stress. J.Biol.Chem. 276, 13935-13940 
62. Kitamura, Y., Miyamura, A., Takata, K., Inden, M., Tsuchiya, D., Nakamura, K., Taniguchi, T. (2003) Possible involvement of both endoplasmic reticulum-and mitochondria-dependent pathways in thapsigargin-induced apoptosis in human neuroblastoma SH-SY5Y cells. J.Pharmacol.Sci. 92, 228-236

63. Nakagawa, T., Zhu, H., Morishima, N., Li, E., Xu, J., Yankner, B. A., Yuan, J. (2000) Caspase-12 mediates endoplasmic-reticulum-specific apoptosis and cytotoxicity by amyloid-beta. Nature 403, 98-103

64. Rao, R. V., Hermel, E., Castro-Obregon, S., del, R. G., Ellerby, L. M., Ellerby, H. M., Bredesen, D. E. (2001) Coupling endoplasmic reticulum stress to the cell death program. Mechanism of caspase activation. J.Biol.Chem. 276, 33869-33874

65. Taylor, J., Ikeda, M. (2000) Role of caspases in neuronal damage. Drug News Perspect. 13, 5-11

66. Nakagawa, T., Zhu, H., Morishima, N., Li, E., Xu, J., Yankner, B. A., Yuan, J. (2000) Caspase-12 mediates endoplasmic-reticulum-specific apoptosis and cytotoxicity by amyloid-beta. Nature 403, 98-103

67. Li, P., Nijhawan, D., Budihardjo, I., Srinivasula, S. M., Ahmad, M., Alnemri, E. S., Wang, X. (1997) Cytochrome c and dATP-dependent formation of Apaf1/caspase-9 complex initiates an apoptotic protease cascade. Cell 91, 479-489

68. Morishima, N., Nakanishi, K., Takenouchi, H., Shibata, T., Yasuhiko, Y. (2002) An endoplasmic reticulum stress-specific caspase cascade in apoptosis. Cytochrome c-independent activation of caspase-9 by caspase-12. J.Biol.Chem. 277, 34287-34294

69. Zou, H., Henzel, W. J., Liu, X., Lutschg, A., Wang, X. (1997) Apaf-1, a human protein homologous to $\mathrm{C}$. elegans CED-4, participates in cytochrome c-dependent activation of caspase-3. Cell 90, 405-413

70. Cohen, G. M. (1997) Caspases: the executioners of apoptosis. Biochem.J. 326 ( Pt 1), $1-16$

71. Namura, S., Zhu, J., Fink, K., Endres, M., Srinivasan, A., Tomaselli, K. J., Yuan, J., Moskowitz, M. A. (1998) Activation and cleavage of caspase-3 in apoptosis induced by experimental cerebral ischemia. J.Neurosci. 18, 3659-3668

72. Hartmann, A., Hunot, S., Michel, P. P., Muriel, M. P., Vyas, S., Faucheux, B. A., Mouatt-Prigent, A., Turmel, H., Srinivasan, A., Ruberg, M., Evan, G. I., Agid, Y., Hirsch, E. C. (2000) Caspase-3: A vulnerability factor and final effector in apoptotic death of dopaminergic neurons in Parkinson's disease.

Proc.Natl.Acad.Sci.U.S.A 97, 2875-2880 
73. Su, J. H., Zhao, M., Anderson, A. J., Srinivasan, A., Cotman, C. W. (2001) Activated caspase-3 expression in Alzheimer's and aged control brain: correlation with Alzheimer pathology. Brain Res. 898, 350-357

74. Li, M., Ona, V. O., Chen, M., Kaul, M., Tenneti, L., Zhang, X., Stieg, P. E., Lipton, S. A., Friedlander, R. M. (2000) Functional role and therapeutic implications of neuronal caspase- 1 and -3 in a mouse model of traumatic spinal cord injury. Neuroscience 99, 333-342

75. Tenneti, L., Lipton, S. A. (2000) Involvement of activated caspase-3-like proteases in N-methyl-D-aspartate-induced apoptosis in cerebrocortical neurons. J.Neurochem. 74, 134-142

76. Benchoua, A., Guegan, C., Couriaud, C., Hosseini, H., Sampaio, N., Morin, D., Onteniente, B. (2001) Specific caspase pathways are activated in the two stages of cerebral infarction. J.Neurosci. 21, 7127-7134

77. Chen, M., Ona, V. O., Li, M., Ferrante, R. J., Fink, K. B., Zhu, S., Bian, J., Guo, L., Farrell, L. A., Hersch, S. M., Hobbs, W., Vonsattel, J. P., Cha, J. H., Friedlander, R. M. (2000) Minocycline inhibits caspase-1 and caspase-3 expression and delays mortality in a transgenic mouse model of Huntington disease. Nat.Med. 6, 797-801

78. Kaufman, R. J. (1999) Stress signaling from the lumen of the endoplasmic reticulum: coordination of gene transcriptional and translational controls. Genes Dev. 13, 1211-1233

79. Mori, K. (2000) Tripartite management of unfolded proteins in the endoplasmic reticulum. Cell 101, 451-454

80. Kaufman, R. J. (1999) Stress signaling from the lumen of the endoplasmic reticulum: coordination of gene transcriptional and translational controls. Genes Dev. 13, 1211-1233

81. Zinszner, H., Kuroda, M., Wang, X., Batchvarova, N., Lightfoot, R. T., Remotti, H., Stevens, J. L., Ron, D. (1998) CHOP is implicated in programmed cell death in response to impaired function of the endoplasmic reticulum. Genes Dev. 12, 982-995

82. Oyadomari, S., Araki, E., Mori, M. (2002) Endoplasmic reticulum stressmediated apoptosis in pancreatic beta-cells. Apoptosis. 7, 335-345

83. Kedersha, N., Anderson, P. (2002) Stress granules: sites of mRNA triage that regulate mRNA stability and translatability. Biochem.Soc.Trans. 30, 963-969

84. Anderson, P., Kedersha, N. (2002) Visibly stressed: the role of eIF2, TIA-1, and stress granules in protein translation. Cell Stress.Chaperones. 7, 213-221 
85. Clemens, M. J. (2001) Initiation factor eIF2 alpha phosphorylation in stress responses and apoptosis. Prog.Mol.Subcell.Biol. 27, 57-89

86. Pestova, T. V., Kolupaeva, V. G., Lomakin, I. B., Pilipenko, E. V., Shatsky, I. N., Agol, V. I., Hellen, C. U. (2001) Molecular mechanisms of translation initiation in eukaryotes. Proc.Natl.Acad.Sci.U.S.A 98, 7029-7036

87. Oyadomari, S., Araki, E., Mori, M. (2002) Endoplasmic reticulum stressmediated apoptosis in pancreatic beta-cells. Apoptosis. 7, 335-345

88. Kedersha, N., Anderson, P. (2002) Stress granules: sites of mRNA triage that regulate mRNA stability and translatability. Biochem.Soc.Trans. 30, 963-969

89. Anderson, P., Kedersha, N. (2002) Visibly stressed: the role of eIF2, TIA-1, and stress granules in protein translation. Cell Stress. Chaperones. 7, 213-221

90. Pestova, T. V., Kolupaeva, V. G., Lomakin, I. B., Pilipenko, E. V., Shatsky, I. N., Agol, V. I., Hellen, C. U. (2001) Molecular mechanisms of translation initiation in eukaryotes. Proc.Natl.Acad.Sci.U.S.A 98, 7029-7036

91. Harding, H. P., Zhang, Y., Ron, D. (1999) Protein translation and folding are coupled by an endoplasmic-reticulum-resident kinase. Nature 397, 271-274

92. Shi, Y., Vattem, K. M., Sood, R., An, J., Liang, J., Stramm, L., Wek, R. C. (1998) Identification and characterization of pancreatic eukaryotic initiation factor 2 alpha-subunit kinase, PEK, involved in translational control. Mol.Cell Biol. 18, 7499-7509

93. Bertolotti, A., Zhang, Y., Hendershot, L. M., Harding, H. P., Ron, D. (2000) Dynamic interaction of BiP and ER stress transducers in the unfolded-protein response. Nat.Cell Biol. 2, 326-332

94. Groenendyk, J., Michalak, M. (2005) Endoplasmic reticulum quality control and apoptosis. Acta Biochim.Pol. 52, 381-395

95. Cantley, L. C., Auger, K. R., Carpenter, C., Duckworth, B., Graziani, A., Kapeller, R., Soltoff, S. (1991) Oncogenes and signal transduction. Cell 64, 281302

96. Yao, R., Cooper, G. M. (1995) Regulation of the Ras signaling pathway by GTPase-activating protein in PC12 cells. Oncogene 11, 1607-1614

97. Scheid, M. P., Lauener, R. W., Duronio, V. (1995) Role of phosphatidylinositol 3$\mathrm{OH}-$ kinase activity in the inhibition of apoptosis in haemopoietic cells: phosphatidylinositol 3-OH-kinase inhibitors reveal a difference in signalling between interleukin-3 and granulocyte-macrophage colony stimulating factor.

Biochem.J. 312 ( Pt 1), 159-162 
98. Minshall, C., Arkins, S., Freund, G. G., Kelley, K. W. (1996) Requirement for phosphatidylinositol 3'-kinase to protect hemopoietic progenitors against apoptosis depends upon the extracellular survival factor. J.Immunol. 156, 939-947

99. Krasilnikov, M. A. (2000) Phosphatidylinositol-3 kinase dependent pathways: the role in control of cell growth, survival, and malignant transformation.

Biochemistry (Mosc.) 65, 59-67

100. Dudek, H., Datta, S. R., Franke, T. F., Birnbaum, M. J., Yao, R., Cooper, G. M., Segal, R. A., Kaplan, D. R., Greenberg, M. E. (1997) Regulation of neuronal survival by the serine-threonine protein kinase Akt. Science 275, 661-665

101. Kulik, G., Klippel, A., Weber, M. J. (1997) Antiapoptotic signalling by the insulin-like growth factor I receptor, phosphatidylinositol 3-kinase, and Akt. Mol.Cell Biol. 17, 1595-1606

102. Kauffmann-Zeh, A., Rodriguez-Viciana, P., Ulrich, E., Gilbert, C., Coffer, P., Downward, J., Evan, G. (1997) Suppression of c-Myc-induced apoptosis by Ras signalling through PI(3)K and PKB. Nature 385, 544-548

103. Segal, R. A., Greenberg, M. E. (1996) Intracellular signaling pathways activated by neurotrophic factors. Annu.Rev.Neurosci. 19, 463-489

104. Brunet, A., Datta, S. R., Greenberg, M. E. (2001) Transcription-dependent and independent control of neuronal survival by the PI3K-Akt signaling pathway. Curr.Opin.Neurobiol. 11, 297-305

105. Jellinger, K., Linert, L., Kienzl, E., Herlinger, E., Youdim, M. B. (1995) Chemical evidence for 6-hydroxydopamine to be an endogenous toxic factor in the pathogenesis of Parkinson's disease. J.Neural Transm.Suppl 46, 297-314

106. Leroy, K., Brion, J. P. (1999) Developmental expression and localization of glycogen synthase kinase-3beta in rat brain. J.Chem.Neuroanat. 16, 279-293

107. Kaytor, M. D., Orr, H. T. (2002) The GSK3 beta signaling cascade and neurodegenerative disease. Curr.Opin.Neurobiol. 12, 275-278

108. Leis, H., Segrelles, C., Ruiz, S., Santos, M., Paramio, J. M. (2002) Expression, localization, and activity of glycogen synthase kinase 3beta during mouse skin tumorigenesis. Mol.Carcinog. 35, 180-185

109. Hetman, M., Cavanaugh, J. E., Kimelman, D., Xia, Z. (2000) Role of glycogen synthase kinase-3beta in neuronal apoptosis induced by trophic withdrawal. J.Neurosci. 20, 2567-2574

110. Cross, D. A., Alessi, D. R., Cohen, P., Andjelkovich, M., Hemmings, B. A. (1995) Inhibition of glycogen synthase kinase-3 by insulin mediated by protein kinase B. Nature 378, 785-789 
111. Hetman, M., Cavanaugh, J. E., Kimelman, D., Xia, Z. (2000) Role of glycogen synthase kinase-3beta in neuronal apoptosis induced by trophic withdrawal. J.Neurosci. 20, 2567-2574

112. Cross, D. A., Alessi, D. R., Cohen, P., Andjelkovich, M., Hemmings, B. A. (1995) Inhibition of glycogen synthase kinase-3 by insulin mediated by protein kinase B. Nature 378, 785-789

113. Frame, S., Cohen, P. (2001) GSK3 takes centre stage more than 20 years after its discovery. Biochem.J. 359, 1-16

114. Diehl, J. A., Cheng, M., Roussel, M. F., Sherr, C. J. (1998) Glycogen synthase kinase-3beta regulates cyclin D1 proteolysis and subcellular localization. Genes Dev. 12, 3499-3511

115. Jonsson, G., Sachs, C. (1970) Synthesis of noradrenaline from 3,4dihydroxyphenylalanine (DOPA) and dopamine in adrenergic nerves of mouse atrium--effect of reserpine, monoamine oxidase and tyrosine hydroxylase inhibition. Acta Physiol Scand. 80, 307-322

116. Sauer, H., Oertel, W. H. (1994) Progressive degeneration of nigrostriatal dopamine neurons following intrastriatal terminal lesions with 6hydroxydopamine: a combined retrograde tracing and immunocytochemical study in the rat. Neuroscience 59, 401-415

117. Curtius, H. C., Wolfensberger, M., Steinmann, B., Redweik, U., Siegfried, J. (1974) Mass fragmentography of dopamine and 6-hydroxydopamine. Application to the determination of dopamine in human brain biopsies from the caudate nucleus. J.Chromatogr. 99, 529-540

118. Andrew, R., Watson, D. G., Best, S. A., Midgley, J. M., Wenlong, H., Petty, R. K. (1993) The determination of hydroxydopamines and other trace amines in the urine of parkinsonian patients and normal controls. Neurochem.Res. 18, 11751177

119. Soto-Otero, R., Mendez-Alvarez, E., Hermida-Ameijeiras, A., Munoz-Patino, A. M., Labandeira-Garcia, J. L. (2000) Autoxidation and neurotoxicity of 6hydroxydopamine in the presence of some antioxidants: potential implication in relation to the pathogenesis of Parkinson's disease. J.Neurochem. 74, 1605-1612

120. Ben-Shachar, D., Eshel, G., Finberg, J. P., Youdim, M. B. (1991) The iron chelator desferrioxamine (Desferal) retards 6-hydroxydopamine-induced degeneration of nigrostriatal dopamine neurons. J.Neurochem. 56, 1441-1444

121. Kumar, R., Agarwal, A. K., Seth, P. K. (1995) Free radical-generated neurotoxicity of 6-hydroxydopamine. J.Neurochem. 64, 1703-1707 
122. Kijima, Y., Ogunbunmi, E., Fleischer, S. (1991) Drug action of thapsigargin on the Ca2+ pump protein of sarcoplasmic reticulum. J.Biol.Chem. 266, 2291222918

123. Lytton, J., Westlin, M., Hanley, M. R. (1991) Thapsigargin inhibits the sarcoplasmic or endoplasmic reticulum Ca-ATPase family of calcium pumps. J.Biol.Chem. 266, 17067-17071

124. Sagara, Y., Fernandez-Belda, F., de, M. L., Inesi, G. (1992) Characterization of the inhibition of intracellular $\mathrm{Ca} 2+$ transport ATPases by thapsigargin.

J.Biol.Chem. 267, 12606-12613

125. Sagara, Y., Wade, J. B., Inesi, G. (1992) A conformational mechanism for formation of a dead-end complex by the sarcoplasmic reticulum ATPase with thapsigargin. J.Biol.Chem. 267, 1286-1292

126. Inesi, G., Sagara, Y. (1992) Thapsigargin, a high affinity and global inhibitor of intracellular Ca2+ transport ATPases. Arch.Biochem.Biophys. 298, 313-317

127. King, I. A., Tabiowo, A. (1981) Effect of tunicamycin on epidermal glycoprotein and glycosaminoglycan synthesis in vitro. Biochem.J. 198, 331-338

128. Martinez, A., Alonso, M., Castro, A., Perez, C., Moreno, F. J. (2002) First nonATP competitive glycogen synthase kinase 3 beta (GSK-3beta) inhibitors: thiadiazolidinones (TDZD) as potential drugs for the treatment of Alzheimer's disease. J.Med.Chem. 45, 1292-1299

129. Klein, P. S., Melton, D. A. (1996) A molecular mechanism for the effect of lithium on development. Proc.Natl.Acad.Sci.U.S.A 93, 8455-8459

130. West, J. R. (1993) Acute and long-term changes in the cerebellum following developmental exposure to ethanol. Alcohol Alcohol Suppl 2, 199-202

131. Jones, K. L., Smith, D. W. (1973) Recognition of the fetal alcohol syndrome in early infancy. Lancet 2, 999-1001

132. Cramer, C., Davidhizar, R. (1999) FAS/FAE: impact on children. J.Child Health Care 3, 31-34

133. Goodlett, C. R., Horn, K. H. (2001) Mechanisms of alcohol-induced damage to the developing nervous system. Alcohol Res.Health 25, 175-184

134. Maier, S. E., Miller, J. A., Blackwell, J. M., West, J. R. (1999) Fetal alcohol exposure and temporal vulnerability: regional differences in cell loss as a function of the timing of binge-like alcohol exposure during brain development. Alcohol Clin.Exp.Res. 23, 726-734 
135. May, P. A., Gossage, J. P. (2001) Estimating the prevalence of fetal alcohol syndrome. A summary. Alcohol Res.Health 25, 159-167

136. Cui, H., Bulleit, R. F. (1998) Potassium chloride inhibits proliferation of cerebellar granule neuron progenitors. Brain Res.Dev.Brain Res. 106, 129-135

137. Famy, C., Streissguth, A. P., Unis, A. S. (1998) Mental illness in adults with fetal alcohol syndrome or fetal alcohol effects. Am.J.Psychiatry 155, 552-554

138. Kelly, S. J., Day, N., Streissguth, A. P. (2000) Effects of prenatal alcohol exposure on social behavior in humans and other species. Neurotoxicol.Teratol. $22,143-149$

139. Mattson, S. N., Riley, E. P. (1998) A review of the neurobehavioral deficits in children with fetal alcohol syndrome or prenatal exposure to alcohol. Alcohol Clin.Exp.Res. 22, 279-294

140. Courchesne, E., Saitoh, O., Townsend, J. P., Yeung-Courchesne, R., Press, G. A., Lincoln, A. J., Haas, R. H., Schriebman, L. (1994) Cerebellar hypoplasia and hyperplasia in infantile autism. Lancet 343, 63-64

141. Ghez, C., Thomas, W. T. (2000) the cerebellum. In principles in neural science (Kandel, E. R., Schwartz, J. H., and Tessell, T. M., eds) pp. 832-851, McGrawHill.

142. Roebuck, T. M., Mattson, S. N., Riley, E. P. (1998) A review of the neuroanatomical findings in children with fetal alcohol syndrome or prenatal exposure to alcohol. Alcohol Clin.Exp.Res. 22, 339-344

143. Goodlett, C. R., Mahoney, J. C., West, J. R. (1989) Brain growth deficits following a single day of alcohol exposure in the neonatal rat. Alcohol 6, 121-126

144. Naassila, M., Daoust, M. (2002) Effect of prenatal and postnatal ethanol exposure on the developmental profile of mRNAs encoding NMDA receptor subunits in rat hippocampus. J.Neurochem. 80, 850-860

145. Perez-Torrero, E., Duran, P., Granados, L., Gutierez-Ospina, G., Cintra, L., DiazCintra, S. (1997) Effects of acute prenatal ethanol exposure on Bergmann glia cells early postnatal development. Brain Res. 746, 305-308

146. Sakata-Haga, H., Sawada, K., Hisano, S., Fukui, Y. (2001) Abnormalities of cerebellar foliation in rats prenatally exposed to ethanol. Acta Neuropathol.(Berl) $102,36-40$

147. Altman, J., Bayer, S. A. (1985) Embryonic development of the rat cerebellum. III. Regional differences in the time of origin, migration, and settling of Purkinje cells. J.Comp Neurol. 231, 42-65 
148. Altman, J., Bayer, S. A. (1985) Embryonic development of the rat cerebellum. II. Translocation and regional distribution of the deep neurons. J.Comp Neurol. 231, $27-41$

149. Altman, J., Bayer, S. A. (1985) Embryonic development of the rat cerebellum. I. Delineation of the cerebellar primordium and early cell movements. J.Comp Neurol. 231, 1-26

150. Altman, J. (1969) Autoradiographic and histological studies of postnatal neurogenesis. 3. Dating the time of production and onset of differentiation of cerebellar microneurons in rats. J.Comp Neurol. 136, 269-293

151. Dobbing, J., Sands, J. (1973) Quantitative growth and development of human brain. Arch.Dis.Child 48, 757-767

152. Dobbing, J., Sands, J. (1979) Comparative aspects of the brain growth spurt. Early Hum.Dev. 3, 79-83

153. Bauer-Moffett, C., Altman, J. (1977) The effect of ethanol chronically administered to preweanling rats on cerebellar development: a morphological study. Brain Res. 119, 249-268

154. Nathaniel, E. J., Nathaniel, D. R., Mohamed, S. A., Nahnybida, L., Nathaniel, L. (1986) Growth patterns of rat body, brain, and cerebellum in fetal alcohol syndrome. Exp.Neurol. 93, 610-620

155. Miller, M. W. (1996) Effect of early exposure to ethanol on the protein and DNA contents of specific brain regions in the rat. Brain Res. 734, 286-294

156. Kaufman, R. J. (1999) Double-stranded RNA-activated protein kinase mediates virus-induced apoptosis: a new role for an old actor. Proc.Natl.Acad.Sci.U.S.A 96, 11693-11695

157. Levin, D., London, I. M. (1978) Regulation of protein synthesis: activation by double-stranded RNA of a protein kinase that phosphorylates eukaryotic initiation factor 2. Proc.Natl.Acad.Sci.U.S.A 75, 1121-1125

158. Tian, B., Mathews, M. B. (2001) Functional characterization of and cooperation between the double-stranded RNA-binding motifs of the protein kinase PKR.

J.Biol.Chem. 276, 9936-9944

159. Ung, T. L., Cao, C., Lu, J., Ozato, K., Dever, T. E. (2001) Heterologous dimerization domains functionally substitute for the double-stranded RNA binding domains of the kinase PKR. EMBO J. 20, 3728-3737

160. Tan, S. L., Katze, M. G. (1999) The emerging role of the interferon-induced PKR protein kinase as an apoptotic effector: a new face of death? J.Interferon Cytokine Res. 19, 543-554 
161. Gil, J., Esteban, M. (2000) Induction of apoptosis by the dsRNA-dependent protein kinase (PKR): mechanism of action. Apoptosis. 5, 107-114

162. Patel, C. V., Handy, I., Goldsmith, T., Patel, R. C. (2000) PACT, a stressmodulated cellular activator of interferon-induced double-stranded RNA-activated protein kinase, PKR. J.Biol.Chem. 275, 37993-37998

163. Williams, B. R. (1999) PKR; a sentinel kinase for cellular stress. Oncogene 18, $6112-6120$

164. Williams, B. R. (2001) Signal integration via PKR. Sci.STKE. 2001, RE2

165. D'Acquisto, F., Ghosh, S. (2001) PACT and PKR: turning on NF-kappa B in the absence of virus. Sci.STKE. 2001, RE1

166. Rowe, T. M., Sen, G. C. (2001) Organizations and promoter analyses of the human and the mouse genes for PACT, the protein-activator of the interferoninduced protein kinase, PKR. Gene 273, 215-225

167. Patel, R. C., Sen, G. C. (1998) PACT, a protein activator of the interferon-induced protein kinase, PKR. EMBO J. 17, 4379-4390

168. Ito, T., Yang, M., May, W. S. (1999) RAX, a cellular activator for doublestranded RNA-dependent protein kinase during stress signaling. J.Biol.Chem. $274,15427-15432$

169. Patel, R. C., Sen, G. C. (1998) PACT, a protein activator of the interferon-induced protein kinase, PKR. EMBO J. 17, 4379-4390

170. Bennett, R. L., Blalock, W. L., May, W. S. (2004) Serine 18 phosphorylation of RAX, the PKR activator, is required for PKR activation and consequent translation inhibition. J.Biol.Chem. 279, 42687-42693

171. Wu, S., Kaufman, R. J. (1996) Double-stranded (ds) RNA binding and not dimerization correlates with the activation of the dsRNA-dependent protein kinase (PKR). J.Biol.Chem. 271, 1756-1763

172. Wu, S., Kaufman, R. J. (1997) A model for the double-stranded RNA (dsRNA)dependent dimerization and activation of the dsRNA-activated protein kinase PKR. J.Biol.Chem. 272, 1291-1296

173. Tan, S. L., Katze, M. G. (1999) The emerging role of the interferon-induced PKR protein kinase as an apoptotic effector: a new face of death? J.Interferon Cytokine Res. 19, 543-554

174. Gunnery, S., Mathews, M. B. (1998) RNA binding and modulation of PKR activity. Methods 15, 189-198 
175. Gale, M., Jr., Katze, M. G. (1998) Molecular mechanisms of interferon resistance mediated by viral-directed inhibition of PKR, the interferon-induced protein kinase. Pharmacol.Ther. 78, 29-46

176. Romano, P. R., Garcia-Barrio, M. T., Zhang, X., Wang, Q., Taylor, D. R., Zhang, F., Herring, C., Mathews, M. B., Qin, J., Hinnebusch, A. G. (1998) Autophosphorylation in the activation loop is required for full kinase activity in vivo of human and yeast eukaryotic initiation factor 2alpha kinases PKR and GCN2. Mol.Cell Biol. 18, 2282-2297

177. Nanduri, S., Rahman, F., Williams, B. R., Qin, J. (2000) A dynamically tuned double-stranded RNA binding mechanism for the activation of antiviral kinase PKR. EMBO J. 19, 5567-5574

178. Zhang, F., Romano, P. R., Nagamura-Inoue, T., Tian, B., Dever, T. E., Mathews, M. B., Ozato, K., Hinnebusch, A. G. (2001) Binding of double-stranded RNA to protein kinase PKR is required for dimerization and promotes critical autophosphorylation events in the activation loop. J.Biol.Chem. 276, 2494624958

179. de, H. C., Mendez, R., Santoyo, J. (1996) The eIF-2alpha kinases and the control of protein synthesis. FASEB J. 10, 1378-1387

180. Clemens, M. J. (1997) PKR--a protein kinase regulated by double-stranded RNA. Int.J.Biochem.Cell Biol. 29, 945-949

181. Williams, B. R. (1999) PKR; a sentinel kinase for cellular stress. Oncogene 18, 6112-6120

182. Polyak, S. J., Tang, N., Wambach, M., Barber, G. N., Katze, M. G. (1996) The P58 cellular inhibitor complexes with the interferon-induced, double-stranded RNA-dependent protein kinase, PKR, to regulate its autophosphorylation and activity. J.Biol.Chem. 271, 1702-1707

183. Lee, T. G., Tang, N., Thompson, S., Miller, J., Katze, M. G. (1994) The 58,000dalton cellular inhibitor of the interferon-induced double-stranded RNA-activated protein kinase (PKR) is a member of the tetratricopeptide repeat family of proteins. Mol.Cell Biol. 14, 2331-2342

184. Tan, S. L., Gale, M. J., Jr., Katze, M. G. (1998) Double-stranded RNAindependent dimerization of interferon-induced protein kinase PKR and inhibition of dimerization by the cellular P58IPK inhibitor. Mol.Cell Biol. 18, 2431-2443

185. Fernandez, J., Yaman, I., Sarnow, P., Snider, M. D., Hatzoglou, M. (2002) Regulation of internal ribosomal entry site-mediated translation by phosphorylation of the translation initiation factor eIF2alpha. J.Biol.Chem. 277, 19198-19205 
186. Antoun, A., Pavlov, M. Y., Andersson, K., Tenson, T., Ehrenberg, M. (2003) The roles of initiation factor 2 and guanosine triphosphate in initiation of protein synthesis. EMBO J. 22, 5593-5601

187. Kapp, L. D., Lorsch, J. R. (2004) GTP-dependent recognition of the methionine moiety on initiator tRNA by translation factor eIF2. J.Mol.Biol. 335, 923-936

188. Webb, B. L., Proud, C. G. (1997) Eukaryotic initiation factor 2B (eIF2B). Int.J.Biochem.Cell Biol. 29, 1127-1131

189. Sudhakar, A., Ramachandran, A., Ghosh, S., Hasnain, S. E., Kaufman, R. J., Ramaiah, K. V. (2000) Phosphorylation of serine 51 in initiation factor 2 alpha (eIF2 alpha) promotes complex formation between eIF2 alpha(P) and eIF2B and causes inhibition in the guanine nucleotide exchange activity of eIF2B.

Biochemistry 39, 12929-12938

190. Chen, J. J., London, I. M. (1995) Regulation of protein synthesis by hemeregulated eIF-2 alpha kinase. Trends Biochem.Sci. 20, 105-108

191. Cox, S., Proud, C. G. (1988) The effect of ethanol on polypeptide chain initiation in reticulocyte lysates. Inhibition of recycling of initiation factor eIF-2.

Biochem.Pharmacol. 37, 2045-2049

192. Sudhakar, A., Ramachandran, A., Ghosh, S., Hasnain, S. E., Kaufman, R. J., Ramaiah, K. V. (2000) Phosphorylation of serine 51 in initiation factor 2 alpha (eIF2 alpha) promotes complex formation between eIF2 alpha(P) and eIF2B and causes inhibition in the guanine nucleotide exchange activity of eIF2B.

Biochemistry 39, 12929-12938

193. Chen, J. J., London, I. M. (1995) Regulation of protein synthesis by hemeregulated eIF-2 alpha kinase. Trends Biochem.Sci. 20, 105-108

194. Clemens, M. J. (1997) PKR--a protein kinase regulated by double-stranded RNA. Int.J.Biochem.Cell Biol. 29, 945-949

195. Wek, R. C. (1994) eIF-2 kinases: regulators of general and gene-specific translation initiation. Trends Biochem.Sci. 19, 491-496

196. Santoyo, J., Alcalde, J., Mendez, R., Pulido, D., de, H. C. (1997) Cloning and characterization of a cDNA encoding a protein synthesis initiation factor-2alpha (eIF-2alpha) kinase from Drosophila melanogaster. Homology To yeast GCN2 protein kinase. J.Biol.Chem. 272, 12544-12550

197. Berlanga, J. J., Santoyo, J., de, H. C. (1999) Characterization of a mammalian homolog of the GCN2 eukaryotic initiation factor 2alpha kinase. Eur.J.Biochem. $265,754-762$ 
198. Harding, H. P., Zhang, Y., Ron, D. (1999) Protein translation and folding are coupled by an endoplasmic-reticulum-resident kinase. Nature 397, 271-274

199. Pestova, T. V., Kolupaeva, V. G., Lomakin, I. B., Pilipenko, E. V., Shatsky, I. N., Agol, V. I., Hellen, C. U. (2001) Molecular mechanisms of translation initiation in eukaryotes. Proc.Natl.Acad.Sci.U.S.A 98, 7029-7036

200. Diaz, J., Samson, H. H. (1980) Impaired brain growth in neonatal rats exposed to ethanol. Science 208, 751-753

201. Pierce, D. R., Goodlett, C. R., West, J. R. (1989) Differential neuronal loss following early postnatal alcohol exposure. Teratology 40, 113-126

202. Borges, S., Lewis, P. D. (1983) The effect of ethanol on the cellular composition of the cerebellum. Neuropathol.Appl.Neurobiol. 9, 53-60

203. Nathaniel, E. J., Nathaniel, D. R., Mohamed, S., Nathaniel, L., Kowalzik, C., Nahnybida, L. (1986) Prenatal ethanol exposure and cerebellar development in rats. Exp.Neurol. 93, 601-609

204. Vary, T. C., Lynch, C. J., Lang, C. H. (2001) Effects of chronic alcohol consumption on regulation of myocardial protein synthesis. Am.J.Physiol Heart Circ.Physiol 281, H1242-H1251

205. Lang, C. H., Wu, D., Frost, R. A., Jefferson, L. S., Vary, T. C., Kimball, S. R. (1999) Chronic alcohol feeding impairs hepatic translation initiation by modulating eIF2 and eIF4E. Am.J.Physiol 277, E805-E814

206. Lang, C. H., Wu, D., Frost, R. A., Jefferson, L. S., Kimball, S. R., Vary, T. C. (1999) Inhibition of muscle protein synthesis by alcohol is associated with modulation of eIF2B and eIF4E. Am.J.Physiol 277, E268-E276

207. Wu, J. M. (1981) Control of protein synthesis in rabbit reticulocytes. Inhibition of polypeptide synthesis by ethanol. J.Biol.Chem. 256, 4164-4167

208. Lang, C. H., Wu, D., Frost, R. A., Jefferson, L. S., Vary, T. C., Kimball, S. R. (1999) Chronic alcohol feeding impairs hepatic translation initiation by modulating eIF2 and eIF4E. Am.J.Physiol 277, E805-E814

209. Lang, C. H., Kimball, S. R., Frost, R. A., Vary, T. C. (2001) Alcohol myopathy: impairment of protein synthesis and translation initiation. Int.J.Biochem.Cell Biol. $33,457-473$ 
Chapter Two: Glycogen Synthase Kinase $3 \beta$ (GSK3ß) Mediates 6Hydroxydopamine (6-OHDA)-induced Neuronal Death 


\begin{abstract}
The causes of sporadic Parkinson's disease (PD) are poorly understood. 6hydroxydopamine (6-OHDA), a PD mimetic, is widely used to model this neurodegenerative disorder in vitro and in vivo; however, the underlying mechanisms remain incompletely elucidated. We demonstrated here that 6-OHDA evoked endoplasmic reticulum (ER) stress which was characterized by an up-regulation in the expression of GRP78 and GADD153 (Chop), the cleavage of procaspase-12, and phosphorylation of eukaryotic initiation factor- $2 \alpha$ in human dopaminergic neuronal cell line (SH-SY5Y) and cultured rat cerebellar granule neurons (CGNs). Glycogen synthase kinase-3 $\beta$ (GSK3 $\beta$ ) responds to ER stress and its activity is regulated by phosphorylation. 6-OHDA significantly inhibited phosphorylation of GSK3 $\beta$ at Ser9, whereas it induced hyperphosphorylation of Tyr216 with little effect on GSK3 $\beta$ expression in SH-SY5Y cells and PC12 cells (a rat dopamine cell line), as well as CGNs. Furthermore, 6-OHDA decreased the expression of cyclin D1, a substrate of GSK3 $\beta$, and dephosphorylated Akt, the upstream signaling component of GSK3 $\beta$. Protein phosphatase 2A (PP2A), an ER stress-responsive phosphatase, was involved in 6-OHDA-induced GSK3 $\beta$ dephosphorylation (Ser9). Blocking GSK3 $\beta$ activity by selective inhibitors (lithium, TDZD-8 and L803-mts) prevented 6-OHDA-induced cleavage of caspase-3, poly(ADPribose) polymerase (PARP), DNA fragmentations, and cell death. With a tetracycline (Tet)-controlled TrkB inducible system, we demonstrated that activation of TrkB in SHSY5Y cells alleviated 6-OHDA-induced GSK3 $\beta$ dephosphorylation (Ser9) and ameliorated 6-OHDA neurotoxicity. TrkB activation also protected CGNs against 6OHDA-induced damage. On the other hand, antioxidants had little effect on 6-OHDA-
\end{abstract}


induced GSK3 $\beta$ activation although they also offered neuroprotection. These results suggest that GSK3 $\beta$ is a critical intermediate in pro-apoptotic signaling cascades that are associated with neurodegenerative diseases, thus providing a potential target site amenable to pharmacological intervention. 


\section{Introduction}

The endoplasmic reticulum is an intracellular compartment involved in calcium signaling and protein folding/processing. Impaired function of the endoplasmic reticulum (ER), commonly referred to as ER stress, is usually caused by alterations in

$\mathrm{Ca}^{2+}$ homeostasis, oxidative stress and accumulation of unfolded proteins. ER stress is now known as an important factor in the neuropathology of a wide variety of neurological disorders (1-3). Exemplary among these is Alzheimer's disease (AD). Neurotoxic effects of amyloid $\beta$-peptides are at least partially targeted to the ER $(4,5)$. Recent genetic evidence indicates that ER stress is associated with Parkinson's disease (PD) $(6,7)$.

The molecular mechanisms of most neurodegenerative disorders remain elusive. For example, although some genetic and environmental factors have been identified as contributing to certain forms of PD, the etiology of this central nervous system disorder remains unknown $(8,9)$. The hallmark of PD is a loss of dopaminergic neurons in the substantia nigra, which leads to clinical and pharmacological abnormalities characterizing the disease. The majority of PD is sporadic, and the cause of neuronal death has not been defined. Recent advances indicate that the excitotoxicity as well as the generation of reactive oxygen species (ROS) are important mediators of neuronal death in PD (10-12). It appears that these events involve mitochondrial abnormality. However, downstream effectors in the death pathway have not been defined, nor is it clear whether mitochondrial events are the sole contributors to neuronal death in PD and other neurodegenerative diseases. Recent studies point to ER stress as a potential mediator of 
pathogenesis of PD. The research using drug models suggests that PD mimetics induce ER stress in cultured neurons $(13,14)$.

Much PD research relies on drug models that mimic the selective dopaminergic neuron degeneration that occurs in this disorder. Agents widely used for this purpose include 6-hydroxydopamine (6-OHDA), 1-methyl-4-phenyl-pyridinium $\left(\mathrm{MPP}^{+}\right)$and rotenone. 6-OHDA is a selective catecholaminergic neurotoxin that is widely used to study mechanisms of cell death in dopaminergic neurons as well as other types of neurons $(13,15-18)$. 6-OHDA can be formed from dopamine by non-enzymatic hydroxylation in the presence of $\mathrm{Fe}^{2+}$ and $\mathrm{H}_{2} \mathrm{O}_{2}$ (19). Endogenous 6-OHDA was detected in the brain and urine samples of patients suffering from PD (20-22), suggesting that this compound is involved in the pathogenesis of PD. The cellular and molecular mechanisms by which 6-OHDA induces neuronal loss, however, are not clear. Human dopaminergic neuronal cell line SH-SY5Y possesses many qualities of substantia nigra neurons (23), and is therefore widely used to study the death of dopaminergic neurons. In the present study, we demonstrate that 6-OHDA induces ER stress in SH-SY5Y cells, and subsequently activates glycogen synthase kinase $3 \beta$ (GSK3 $\beta$ ), an ER stressresponsive component. Furthermore, our study reveals that GSK3 $\beta$ plays a critical role in 6-OHDA-induced death of neuronal cells. 


\section{Materials and Methods}

\section{Materials}

Tetracycline (Tet), thapsigargin (Tha), tunicamycin (Tun), LiCl, okadaic acid (OA), $N$-acetylcysteine (NAC), tert-butylhydroquinone (tBHQ) and 6-hydroxydopamine (6-OHDA) were obtained from Sigma Chemical Co. (St Louis, MO). All of the antibodies except anti-actin and anti-p-GSK3 $\beta$ (Tyr216) were obtained from Cell Signaling Technology, Inc. (Beverly, MA). The anti-actin antibody was purchased from Santa Cruz Biotechnology (Santa Cruz, CA) and the anti-p-GSK3 $\beta$ (Tyr216) antibody was obtained from Oncogene Research Products (San Diego, CA). Inhibitors of GSK3 $\beta$ (TDZD-8; L803-mts), glutathione monoethyl ester (GSH-MEE), Trolox (a derivative of vitamin E) and (-)-Epigallocatechin gallate (EGCG) were purchased from Calbiochem (La Jolla, CA).

\section{Cell culture and treatment}

SH-SY5Y cells and PC12 cells were obtained from ATCC. SH-SY5Y cells were grown in Eagle's MEM containing 10\% fetal bovine serum (FBS), 2 mM L-glutamine and $25 \mu \mathrm{g} / \mathrm{ml}$ gentamicin at $37^{\circ} \mathrm{C}$ with $5 \% \mathrm{CO}_{2}$. PC12 cells were maintained in RPMI1640 medium containing 5\% FBS, 10\% horse serum, 100 units/ml penicillin and 100 $\mu \mathrm{g} / \mathrm{ml}$ streptomycin. SH-SY5Y cells expressing inducible TrkB (TB3 and TB8 cells) were generated under the control of a Tet-repressible promoter element (24). TrkB is a high affinity receptor for brain derived neurotrophic factor (BDNF). Culture and treatment of TB3 and TB8 cells were previously described (24).

Cerebellar granule neurons (CGNs) were also selected for this study because 6OHDA induces apoptosis in these neurons $(17,25-27)$. Cultures of CGNs were created 
using a previously described method $(28,29)$. Sprague Dawley rats were obtained from Hilltop Laboratory Inc. (Scottdale, PA). Briefly, cerebella were obtained from 7-day-old rat pups, minced with a sterile razor blade, and suspended in $10 \mathrm{ml}$ of trypsin solution $(0.025 \%)$ at $37^{\circ} \mathrm{C}$. After incubation for $15 \mathrm{~min}$, an equal volume of solution containing DNAse (130 Knuitz units $/ \mathrm{ml})$ and trypsin inhibitor $(0.75 \mathrm{mg} / \mathrm{ml})$ were added and the tissue was sedimented by a brief ( 5 seconds) centrifugation. The tissue was dissociated by trituration, and the cell suspension was centrifuged through a $4 \%$ bovine serum albumin solution. The cell pellet was re-suspended in Eagle's MEM containing the following supplements: 10\% FBS, $25 \mathrm{mM} \mathrm{KCl}, 1 \mathrm{mM}$ glutamine, $33 \mathrm{mM}$ glucose, and penicillin (100 units $/ \mathrm{ml}) /$ streptomycin $(100 \mu \mathrm{g} / \mathrm{ml})$. Cells (seeding density of 3.2-6.4 x $10^{4} / \mathrm{cm}^{2}$ ) were plated into poly-D-lysine (PDL, $50 \mu \mathrm{g} / \mathrm{ml}$ )-coated culture wells or dishes. Cells were incubated at $37^{\circ} \mathrm{C}$ in a humidified environment containing $5 \% \mathrm{CO}_{2}$ for at least 24 hours before initiating 6-OHDA treatment. For blocking GSK3 $\beta$ activity, cells were treated with $\mathrm{LiCl}(222)$, TDZD-8 $(10 \mu \mathrm{M})$ or L803-mts $(5-20 \mu \mathrm{M})$ for $30-60$ minutes prior to 6-OHDA exposure.

\section{Cell viability}

MTT assay: The MTT assay was employed to determine the number of viable cells in culture (Roche Molecular Biochemicals. Indianapolis, IN) as previously described (30). The assay is based on the cleavage of the yellow tetrazolium salt MTT [3-(4,5-dimethylthiazol-2yl)-2,5-diphenyl tetrazolium bromide] to purple formazan crystals by metabolically active cells. Briefly, the cells were plated into 96-well microtiter plates and exposed to 6-OHDA $(0$ or $50 \mu \mathrm{M})$ for $48 \mathrm{~h}$. Following 6-OHDA 
exposure, $10 \mu \mathrm{l}$ of MTT labeling reagent were added to each well and the plates were incubated at $37^{\circ} \mathrm{C}$ for $4 \mathrm{~h}$. The cultures were then solubilized and spectrophotometric absorbance of the samples was detected by a microtiter plate reader. The wavelength to measure absorbance of formazan product is $570 \mathrm{~nm}$, with a reference wavelength of 750 nm.

\section{Apoptosis assay}

Accumulation of DNA fragments in the cytoplasm of apoptotic cells was determined by ELISA (Roche Molecular Biochemicals). We have demonstrated that this measurement was sensitive to quantify neuronal apoptosis and was consistent with other morphometric indices of apoptosis $(29,31)$. Briefly, the cells were maintained in 96-well

plates. After treatment, the cultures were washed twice with 0.01 M PBS, and the cultured cells were lysed. Twenty microliters of cell lysate from each well were mixed with $80 \mu \mathrm{l}$ of antibody solution in the coated wells. The loaded wells were incubated at room temperature for $2 \mathrm{~h}$. Substrate was added to each well after it was washed three times in incubation buffer. After incubation at room temperature for 10-20 min, the optical density was measured using a microtiter plate reader with a light filter of $405 \mathrm{~nm}$. The readings were used to measure the degree of apoptosis.

Northern blot analysis

Total RNA was extracted from TB3 and TB8 cells cultured in either Tet-on or Tet-off conditions. RNA isolation and hybridization were performed as described previously (32). Thirty $\mu \mathrm{g}$ of total RNA for TrkB was eletrophoresed in $1.2 \%$ agarose- 
6\% formaldehyde gels. Gels were stained with $2 \mathrm{mg} / \mathrm{ml}$ ethidium bromide. Hybridization was performed with ${ }^{32} \mathrm{P}$-labeled insert DNA isolated from a plasmid containing TrkB (33).

\section{Immunoblotting}

The immunoblotting procedure for detecting phosphorylation and expression of signal proteins was performed as previously described (34). Briefly, cells were washed with PBS and lysed with RIPA buffer for 10 minutes, solubilized cells were centrifuged, the supernatant was collected, and the protein concentration was determined. Aliquots of the protein $(40 \mu \mathrm{g})$ were loaded onto the lanes of a sodium dodecylsulfate (SDS) $10 \%$ polyacrylamide gel. The proteins were separated by electrophoresis, and the separated proteins were transferred to nitrocellulose membranes. The membranes were blocked with either 5\% nonfat dry milk or 5.0\% BSA (for detection of phosphorylation) in $10 \mathrm{mM}$ phosphate-buffered saline ( $\mathrm{pH} 7.4)$ and $0.05 \%$ Tween-20 (TPBS) at room temperature for one hour to block non-specific immunoreactivity. Subsequently, the membranes were incubated with primary antibodies directed against signaling proteins for 2 hours at room temperature or overnight at $4^{\circ} \mathrm{C}$. After two quick washes in TPBS, the membranes were incubated with a secondary antibody conjugated to horseradish peroxidase (Amersham, Arlington Hts. IL) diluted at 1:2000 in TPBS for 1 hour. The immune complexes were

detected by the enhanced chemiluminescence method (Amersham). In some cases, the blots were stripped and re-probed with an anti-actin antibody.

\section{Statistical analysis}


Differences among treatment groups were tested using analysis of variance (ANOVA). Differences in which $p$ was less than 0.05 were considered statistically significant. In cases where significant differences were detected, specific post-hoc comparisons between treatment groups were examined with Student-Newman-Keuls tests. 


\section{Results}

6-OHDA induces endoplasmic reticulum (ER) stress and apoptosis

ER stress, which is triggered by the loss of calcium homeostasis or an accumulation of unfolded/misfolded proteins in the ER lumen, is generally characterized by up-regulation of GRP78 and GADD153, phosphorylation of eukaryotic initiation factor-2 alpha (eIF2 $\alpha)$ and cleavage of ER-specific procaspase-12 $(5,35-38)$. 6-OHDA exposure caused a significant increase in the expression of GRP78, GADD153 and the phosphorylation of eIF2 $\alpha$ at Ser51 in SH-SY5Y cells (Fig. 2.1A), indicating the occurrence of ER stress. Similarly, we observed a significant up-regulation of GRP78 and GADD153, phosphorylation of eIF2 $\alpha$, and cleavage of procaspase-12 in primary cultures of cerebellar granule neurons (CGNs) (Fig. 2.1B). Thapsigargin and tunicamycin are the most widely applied agents to experimentally induce ER stress (39, 40). Thapsigargin inhibits ER-associated $\mathrm{Ca}^{2+}$-ATPase and disrupts $\mathrm{Ca}^{2+}$ homeostasis (41). On the other hand, tunicamycin is known to specifically inhibit $N$-glycosylation in the ER (5). As positive controls, these ER stress inducers up-regulated expression of GRP78 and GADD153, phosphorylation of eIF2 $\alpha$, and cleavage of procapase-12 (data not shown). Furthermore, 6-OHDA exposure decreased cell number regardless of serum content in the medium (Fig. 2.2A and 2.2B). It was noted that 6-OHDA induced a decrease in cell number in the serum-containing medium which became more evident than in serum-free medium after day 2. It is known that GSK3 $\beta$ activation can cause suppression of cell proliferation in addition to cell death. SH-SY5Y cells were proliferating in serum-containing medium, but not in serum-free medium. It was likely the more severe reduction of cell number that occurred in serum-containing medium was 
a combined effect of 6-OHDA on cell proliferation and cell death. Therefore, serum-free medium was selected for all subsequent experiments to eliminate the confounding effect of cell proliferation. The alteration in cell number was accompanied by an increase in apoptosis that was quantified by DNA fragmentation (Fig. 2.2C). 6-OHDA-induced apoptosis was further verified by the evidence of caspase-3 activation and cleavage of poly(ADP-ribose) polymerase (PARP) (Fig. 2.2D). Thapsigargin and tunicamycin also induced apoptosis of SH-SY5Y cells to an extent similar to that caused by 6-OHDA (Fig. $2.2 \mathrm{~B}$ and $2.2 \mathrm{C})$.

\section{6-OHDA activates GSK3 $\beta$}

GSK3 $\beta$ is a kinase that plays a pivotal role in numerous cellular functions ranging from glycogen metabolism and modulation of microtubule dynamics to the regulation of cell survival $(42,43)$. A recent study indicates that ER stress may activate GSK3 $\beta$ by inducing dephosphorylation at Ser9 (39). Since 6-OHDA induced ER stress, we sought to determine whether 6-OHDA could regulate GSK3 $\beta$ phosphorylation. The activity of GSK3 $\beta$ is regulated negatively by the phosphorylation of serine 9 (Ser9) and positively by the phosphorylation of tyrosine 216 (Tyr216) (43). As shown in Fig. 2.3A, 6-OHDA inhibited phosphorylation of GSK3 $\beta$ at Ser9, whereas it stimulated phosphorylation at Tyr216 in SH-SY5Y cells. The effect of 6-OHDA on GSK3 $\beta$ phosphorylation diminished after $24 \mathrm{~h}$ of exposure. 6-OHDA had little effect on the expression of GSK3 $\beta$. PC12 cells are a rat dopamine cell line that has been extensively used for studying the mechanism of PD mimetic-induced damage. As shown in Fig. 2.3B, 6OHDA also induced dephosphorylation of GSK3 $\beta$ at Ser9 without affecting its expression levels in PC12 cells. Similarly, 6-OHDA-mediated dephosphorylation of 
GSK3 $\beta$ at Ser9 was observed in cultured CGNs (Fig. 2.3C). Akt is one of the most important upstream signaling components that regulate GSK3 $\beta$ phosphorylation at Ser9 (43). 6-OHDA also induced a transient inhibition of Akt phosphorylation at Ser473 in SH-SY5Y cells, PC12 cells and CGNs (Fig. 2.3). Cyclin D1 is a substrate of GSK3 $\beta$; phosphorylation of cyclin D1 by GSK3 $\beta$ facilitates an ubiquitin-dependent degradation of cyclin D1 $(44,45)$. 6-OHDA down-regulated cyclin D1 in SH-SY5Y cells and PC12 cells (Fig. 2.3D), indicating the activation of GSK3 $\beta$. For a comparison, two ER stress inducers (thapsigargin and tunicamycin), also dephosphorylated GSK3 $\beta$ at Ser9 in a similar pattern (Fig. 2.3E). It has been demonstrated that ER stress-induced GSK3 $\beta$ dephosphorylation (Ser9) is mediated by PP2A in SH-SY5Y cells (39). We sought to determine whether PP2A was involved in 6-OHDA-mediated GSK3 $\beta$ dephosphorylation. As shown in Fig. 2.4, blocking PP2A activity by okadaic acid $(1 \mathrm{nM})$ eliminated 6OHDA-mediated GSK3 $\beta$ dephosporylation (Ser9). At concentrations less than $5 \mathrm{nM}$, okadaic acid specifically blocks PP2A activity without affecting PP1 (46).

\section{6-OHDA-induced cell death is mediated by GSK3 $\beta$.}

It has been recently recognized that GSK3 $\beta$ is an important modulator of apoptosis $(42,43)$. To determine whether 6-OHDA-induced neuronal apoptosis was mediated by GSK3 $\beta$, we blocked GSK3 $\beta$ activity by pre-incubating SH-SY5Y cells with lithium, a widely used selective GSK3 $\beta$ inhibitor (47), or a synthetic chemical GSK3 $\beta$ inhibitor (TDZD-8). TDZD-8 has been shown to specifically inhibit GSK3 $\beta$ activity with little effect on other kinases (47). After pre-treatment with GSK3 $\beta$ inhibitors, SH-SY5Y cells were exposed to 6-OHDA and cell death was evaluated. As shown in Figs. 2.5A 
and 2.5B, pretreatment with TDZD-8 eliminated 6-OHDA-induced cell death as measured by cell viability (MTT assay) and apoptosis (DNA fragmentation ELISA). Lithium also significantly rescued SH-SY5Y cells from 6-OHDA-induced cell death. Furthermore, TDZD-8 and lithium blocked 6-OHDA-mediated caspase-3 activation and cleavage of PARP (Fig. 2.5C), which confirmed the neuroprotective effect of GSK3 $\beta$ inhibitors. Similarly, neuroprotection by TDZD-8 and lithium against 6-OHDA-induced damage was observed in cultured CGNs (Fig. 2.5D). Involvement of GSK3 $\beta$ in 6OHDA-induced cell death was further verified using a novel cell-permeable peptide inhibitor of GSK3 $\beta$ (L803-mts). L803-mts is a substrate-specific, competitive phosphorylated peptide inhibitor of GSK $3 \beta$. This inhibitor is shown to selectively block GSK3 $\beta$ activity without affecting the activity of other kinases (48). L803-mts significantly protected SH-SY5Y and PC12 cells against 6-OHDA-induced cell death in a concentration dependent manner (Fig. 2.5E). Only 5 and $10 \mu \mathrm{M}$ were used in SH-SY5Y cells because L803-mts was cytotoxic for these cells at the concentrations $\geq 20 \mu \mathrm{M}$. L803-mts blocked 6-OHDA-induced down-regulation of cyclin D1 (Fig. 2.5F), indicating that this peptide effectively inhibited GSK3 $\beta$ activity.

TrkB activation induces GSK3 $\beta$ phosphorylation and protects neuronal cells from 6OHDA-induced death

The survival, differentiation and function of neurons are regulated by a family of growth factors called neurotrophins (NTs), which includes nervous growth factor (NGF), brain derived neurotrophic factor (BDNF), NT-3 and NT-4/5 (49). The effects of NTs 
are mediated by the tyrosine kinase receptor of the Trk family at the cytoplasmic membrane (TrkA, TrkB and TrkC). BDNF binds to TrkB and initiates a number of antiapoptotic signaling pathways including phosphatidylinositol 3-kinase (PI3K)/Akt pathway $(24,49,50)$. Activated Akt promotes GSK3 $\beta$ phosphorylation at Ser9 resulting in its inhibition (43). SH-SY5Y cells express low levels of TrkB and barely respond to BDNF. With a Tet-regulated inducible TrkB expression system (TB8 and TB3 cells), we were able to determine whether TrkB activation can override 6-OHDA-mediated GSK3 $\beta$ dephosphorylation (Ser9) and provide protection against 6-OHDA-induced cell death. In the Tet-off condition (no Tet in culture medium), TrkB expression was induced in both TB8 and TB3 cells (derivatives of SH-SY5Y cells)(Fig. 2.6A). Activation of TrkB by BDNF in Tet-off TB8 cells induced phosphorylation of GSK3 $\beta$ at Ser9, which presumably inhibits the activation of GSK3 $\beta$ (Fig. 2.6B). Furthermore, BDNF alleviated 6-OHDA-induced GSK3 $\beta$ dephosphorylation (Ser9) in TB8 cells expressing high TrkB (Tet-off condition, Fig. 2.6C), but not in a Tet-on condition (data not shown). More importantly, BDNF significantly ameliorated 6-OHDA-induced cell death in Tet-off TB8 cells; however, it was ineffective at protecting TB8 cells in a Tet-on condition (Figs. 2.7A and 2.7B). A similar result was observed with TB3 cells (data not shown). Similarly, BDNF significantly protected CGNs from 6-OHDA-induced cell death (Fig. 2.5D); these cells are known to express TrkB, but not TrkA (51). 6-OHDA neurotoxicity may be mediated by oxidative stress. To determine whether oxidative stress was involved in 6-OHDA-induced GSK3 $\beta$ activation, we examined the effect of various antioxidants on 6-OHDA-induced cell death and GSK3 $\beta$ activation. As shown in Fig. $2.8 \mathrm{~A}$, these antioxidants offered significant neuroprotection against 6-OHDA-induced 
cell death. However, none of these antioxidants significantly affected 6-OHDA-mediated GSK3 $\beta$ dephosphorylation (Ser9). Results obtained from the treatment of NAC and GSH-MEE are presented (Fig. 2.8B). 


\section{Discussion}

The mimetics of Parkinson's disease (PD), such as 6-hydroxydopamine (6OHDA), 1-methyl-4-phenyl-pyridinium $\left(\mathrm{MPP}^{+}\right)$and rotenone have been widely used to model this neurodegenerative disorder. However, the mechanisms mediating their activation of a neurodegenerating program remain incompletely elucidated. We demonstrate here that 6-OHDA, a PD mimetic, causes ER stress which is characterized by increase in ER chaperones and the phosphorylation of eIF2 $\alpha$. 6-OHDA induces cell death and activates apoptotic signaling, such as caspase-3 activation and cleavage of PARP. These findings are supported by recent studies which show PD mimetics could induce unfolded protein response (UPR) and the expression of genes involved in ER stress response $(13,14)$. More importantly, our study reveals that glycogen synthase kinase $3 \beta$ (GSK3 $\beta)$ is a key intermediate for 6-OHDA-triggered apoptotic signaling; blocking GSK3$\beta$ activity by selective inhibitors or by activation of TrkB eliminates 6OHDA-mediated caspase-3 activation, cleavage of PARP and DNA fragmentation.

GSK3, a serine/threonine kinase originally identified as a regulator of glycogen metabolism, is also a central component of the Wnt signaling pathway important for proper axis formation during embryonic development (52). There are two highly homologous forms of GSK3 in mammals, GSK3 $\alpha$ and GSK3 $\beta$. GSK3 $\beta$ is particularly abundant in the central nervous system, where it is localized primarily in neurons (53). Recent studies indicate that cellular stress, such as ER stress, oxidative stress, heat shock and hyperosmotic stress, can modulate the activity of $\operatorname{GSK} 3 \beta(39,43,54)$. GSK3 is unusual in that it appears to be largely regulated by inhibition. One mean by which 
GSK3 $\beta$ can be inactivated is through phosphorylation of Ser9. Numerous kinases, such as Akt/protein kinase $\mathrm{B}(\mathrm{PKB})$, protein kinase $\mathrm{C}(\mathrm{PKC})$, p70 S6 kinase, p90Rsk and protein kinase A (PKA) can phosphorylate GSK3 $\beta$ at Ser9 and therefore inactivate $\operatorname{GSK} 3 \beta(42,43)$. GSK3 $\beta$ is also capable of being regulated by an activation pathway. Activation of GSK3 $\beta$ is accomplished by phosphorylation at Tyr216; research on mechanisms of phosphorylation of GSK3 $\beta$ at Tyr216 is relatively sparse. Available evidence indicates that phosphorylation at Tyr216 can be regulated by alterations in intracellular calcium levels or by Fyn, a member of the Src tyrosine kinase family (55, $56)$.

Our study shows that 6-OHDA induces GSK3 $\beta$ dephosphorylation (Ser9). It has been reported that cellular stress, such as ER stress or hyperosmotic stress, can activate protein phosphatase $2 \mathrm{~A}$ and $2 \mathrm{~B}$ ( $\mathrm{PP} 2 \mathrm{~A}$ and $\mathrm{PP} 2 \mathrm{~B})(39,46,54)$. $\mathrm{PP} 2 \mathrm{~A}$ is known to dephosphorylate Akt and GSK3 $\beta$ at Ser9 (57-59). Induction of ER stress by thapsigargin and tunicamycin dephosphorylates GSK3 $\beta$ at Ser9; blocking PP2A activation eliminates ER stress-mediated dephosphorylation (39). Similarly, our results show that blockage of PP2A abolishes 6-OHDA-induced GSK3 $\beta$ dephosphorylation, suggesting that the alteration in GSK3 $\beta$ phosphorylation results from ER stress. 6-OHDA increases GSK3 $\beta$ phosphorylation at Tyr216; this may involve an alteration in the intracellular calcium concentration since it has been shown that 6-OHDA can change the expression of calcium binding proteins and disrupt intracellular calcium homeostasis (60-62). As mentioned above, calcium homeostasis is a key mediator of GSK3 $\beta$ phosphorylation at Tyr216 (55). 
The ER is an intracellular compartment that plays an important role in the maintenance of $\mathrm{Ca}^{2+}$ homeostasis and proper folding of newly synthesized membranous and secretory proteins (2). Conditions associated with ER dysfunction induce highly conserved stress responses. These include the unfolded protein response (UPR), the ER overloaded response (EOR) and the ER-associated degradation (ERAD) (63). Accumulating evidence indicates that ER stress may be a common denominator for acute brain injury (e.g., cerebral ischemia) and chronic degenerative diseases (e.g. Alzheimer's disease and Parkinson's disease) $(2,42)$. However, the mechanisms underlying ER stress-triggered neurodegeneration are unclear. We demonstrate that dopaminergic cells (SH-SY5Y and PC12 cells) and glutamatergic neurons (cerebellar granule neurons) display a similar response to 6-OHDA, suggesting that 6-OHDA-evoked ER-stress and the activation of GSK3 $\beta$ may not be restricted to dopaminergic neurons. It has been suggested that 6-OHDA-evoked neuronal apoptosis is independent of cell type and does not require a dopamine transporter (64). More importantly, our results link PD mimeticevoked ER stress to GSK3 $\beta$ activation, providing an important insight into the relationship between ER stress and degenerative diseases.

A growing body of evidence suggests that GSK3 $\beta$ is an important modulator of apoptosis. It appears that GSK3 $\beta$ activity correlates inversely with neuronal viability (39, 65-67). For example, over-expression of GSK3 $\beta$ in specific regions of the brain in adult mice results in neuronal death in these regions (67). Neuronal apoptosis induced by trophic withdrawal also appears mediated by GSK3 $\beta$ activation (66). GSK3 $\beta$ has been directly linked to several key neuropathological mechanisms of Alzheimer's disease (AD) $(42,68)$. The mechanisms by which GSK3 $\beta$ facilitates apoptosis have yet to be 
identified. GSK3 $\beta$ has a broad spectrum of substrates. One, and perhaps the most important mechanism, is that it inhibits activation of many transcription factors. Several transcription factors that are known targets of GSK3 $\beta$ regulate cell survival. These include NFAT, HSF-1, CREB, AP-1 and NF-кB $(42,43)$. Furthermore, recent evidence suggests that subcellular redistribution of GSK3 $\beta$ to the nucleus may also trigger a proapoptotic signaling cascade (69).

Under physiological conditions, 6-OHDA can be oxidized to generate reactive oxygen species (ROS) and many neurotoxic effects of 6-OHDA are believed to be mediated by oxidative stress (70-75). Various antioxidants, such as NAC, tBHQ, GSH, EGCG, have been previously shown to protect neuronal cells against 6-OHDA-induced cell death (71-75). Consistent with these findings, we show here that antioxidants offer significant neuroprotection; however, these antioxidants have little effect on 6-OHDAmediated GSK3 $\beta$ dephosphorylation. This result suggests that oxidative stress is minimally involved in the ER stress-GSK3 $\beta$ pathway.

Selective GSK3 $\beta$ inhibitors eliminate 6-OHDA neurotoxicity in these neuronal cells, indicating that GSK3 $\beta$ is a key component of the proapoptotic signaling cascade. Neurotrophic factors, such as glial cell line-derived neurotrophic factor (GDNF) and brain-derived neurotrophic factor (BDNF), are promising agents for neuroprotective therapies. The GDNF receptor is distributed in the substantia nigra (SN) neurons, and its neuroprotective action is mainly mediated by the PI3K/Akt pathway (76-79). A recent study demonstrates that GDNF significantly mitigates 6-OHDA-induced chromatin condensation and DNA fragmentation in a dopaminergic MN9D cell line; the neuroprotection is mediated by the PI3K/Akt pathway (79). Akt is up-stream of GSK3 $\beta$, 
and its activation results in an inhibition of GSK $3 \beta$. It is likely, therefore, that GSK3 $\beta$ is involved in GDNF-mediated neuroprotection. Neurotrophin receptors (TrkA, TrkB and TrkC) regulate neuronal survival; activation of TrkB causes enhanced Akt activity (24, 80-82). TrkB is expressed in the $\mathrm{SN}$ neurons $(83,84)$. The activation of TrkB is shown to promote the survival of the $\mathrm{SN}$ neurons and protect the $\mathrm{SN}$ neurons against excitotoxic insult $(85,86)$. Our results show that activation of TrkB can override 6-OHDA-mediated GSK3 $\beta$ dephosphorylation (Ser9) and protect neurons against 6-OHDA-induced damage. These results suggest that neuroprotection provided by growth factors/neurotrophins or GSK3 $\beta$ inhibitors may share the same mechanism, that is, the modulation of a common intermediate, GSK3 $\beta$. Therefore, the development of selective and safe GSK3 $\beta$ inhibitors may provide a therapeutic benefit in alleviating or slowing down the progression of neurodegeneration. 
Figures 
A

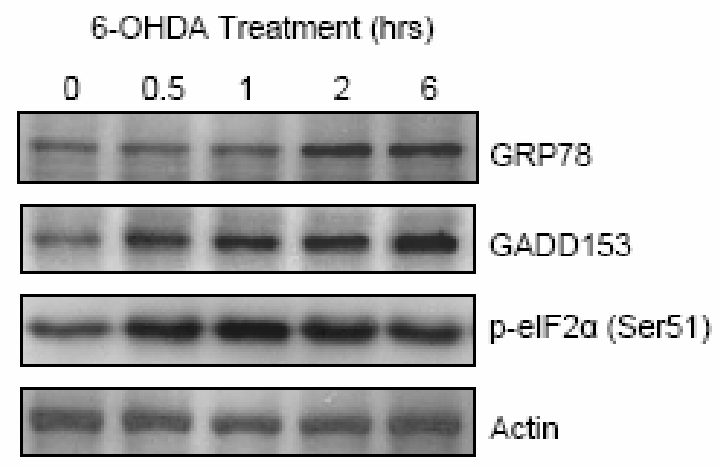

B

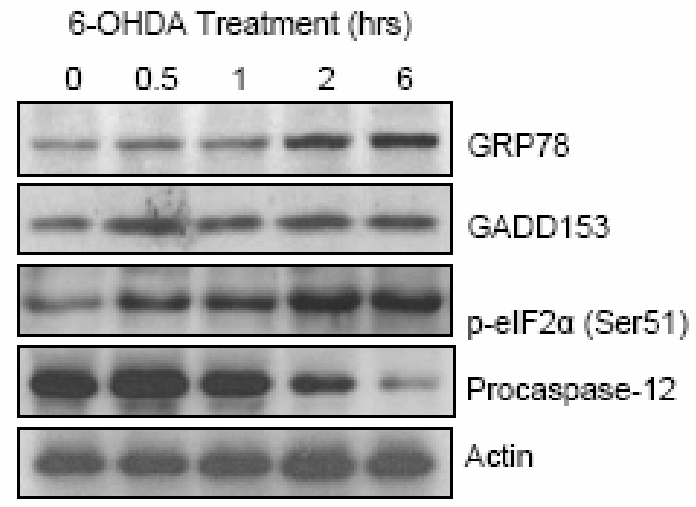

\section{Figure 2. 1 6-OHDA-induced ER stress}

(A) SH-SY5Y cells were cultured in serum-free medium for $24 \mathrm{~h}$. Cells were exposed to 6-OHDA (0 or $50 \mu \mathrm{M})$. The expression of GRP78, GADD153 and phosphorylation of eIF2 $\alpha$ (Ser51) were determined by immunoblots. (B) CGNs were isolated from 7-dayold rat pups, maintained in serum-free medium and exposed to 6-OHDA (50 $\mu \mathrm{M})$. The expression of GRP78, GADD153, procaspase-12 and phosphorylation of eIF2 $\alpha$ were determined by immunoblots. The experiment was replicated three times. 

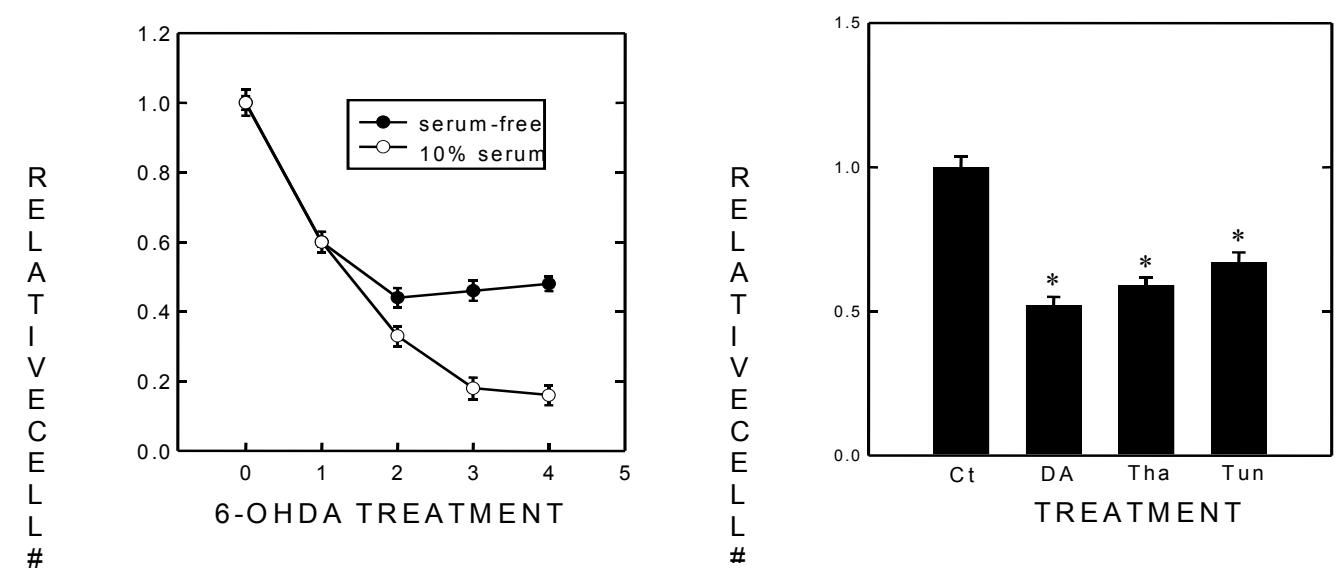

C
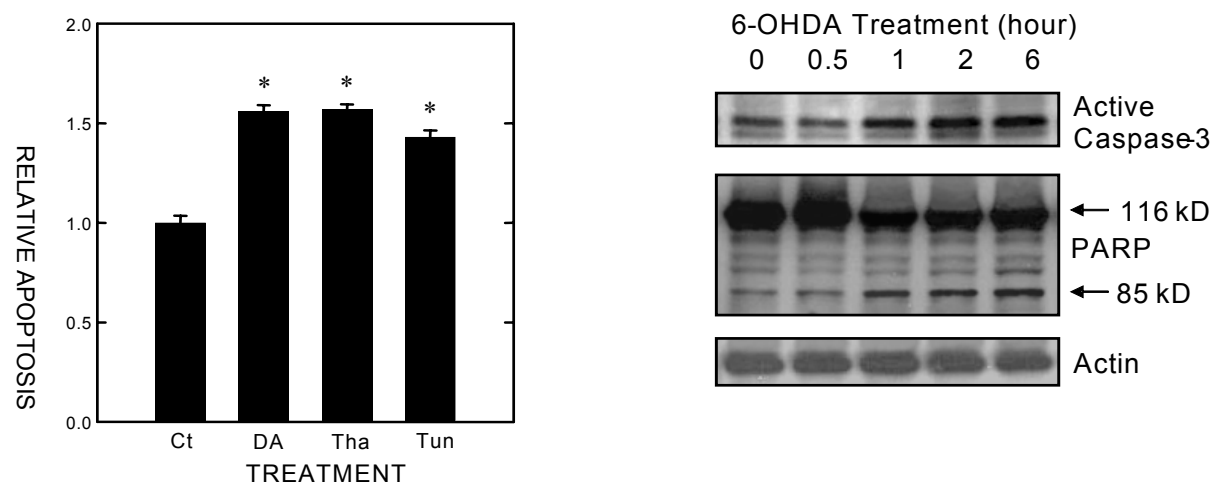
Figure 2. 2 6-OHDA-induced apoptosis of SH-SY5Y cells

(A) Cells were exposed to 6-OHDA $(0$ or $50 \mu \mathrm{M})$ and the number of viable cells was determined by MTT assay as described under the Materials and Methods. 6-OHDAmediated alterations were expressed as a percentage of the control. (B) Cells were exposed to 6-OHDA (DA, $50 \mu \mathrm{M}$ ), thapsigargin (Tha, $1 \mu \mathrm{M}$ ) and tunicamycin (Tun, 3 $\mu \mathrm{g} / \mathrm{ml}$ ) for $30 \mathrm{~h}$ and a relative number of viable cells was determined. Each data point represents the mean \pm SEM of five replications. $* \mathrm{p}<0.05$, statistically significant differences between the controls and 6-OHDA- or Tha/Tun-treated cultures. (C) Quantification of apoptosis with DNA fragmentation ELISA. Cells were exposed to 6OHDA (DA, $50 \mu \mathrm{M}$ ), thapsigargin (Tha, $1 \mu \mathrm{M}$ ) and tunicamycin (Tun, $3 \mu \mathrm{g} / \mathrm{ml}$ ) for $30 \mathrm{~h}$. Relative apoptosis was determined with DNA fragmentation ELISA as described under the Materials and Methods. Each data point represents the mean \pm SEM of four replications. $* \mathrm{p}<0.05$, statistically significant differences between the controls and 6OHDA- or Tha/Tun-treated cultures. (D) Activation of caspase-3 and cleavage of PARP. Cells were exposed to 6-OHDA $(50 \mu \mathrm{M})$ and the expression of active (cleaved) caspase-3 and PARP was determined with immunoblots. The experiment was replicated three times. 


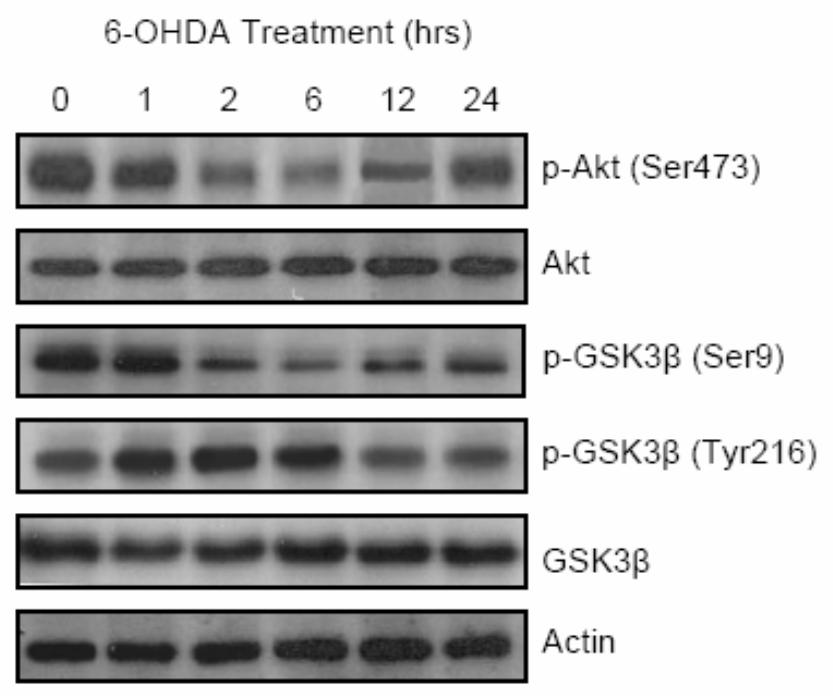

B

6-OHDA Treatment (hrs)

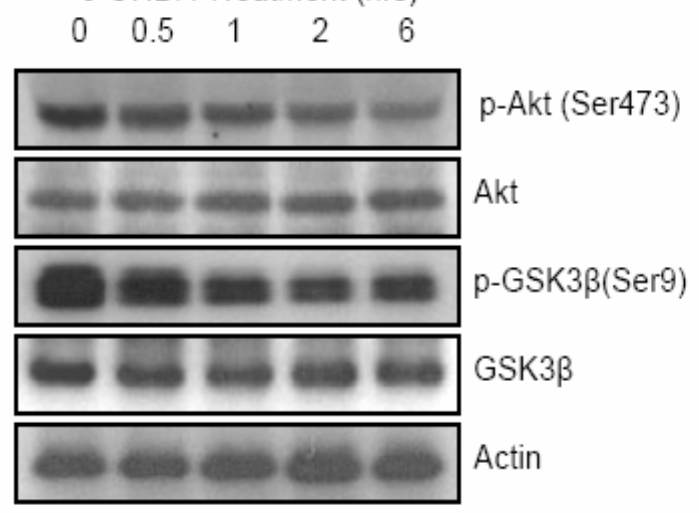

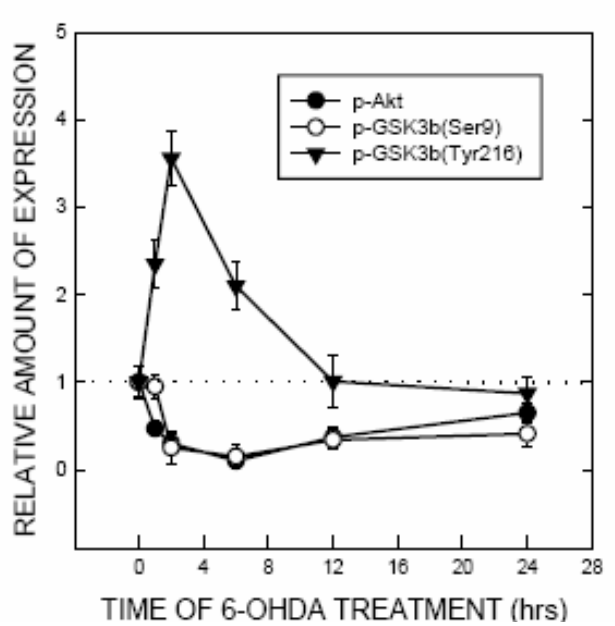

C

6-OHDA Treatment (hrs)

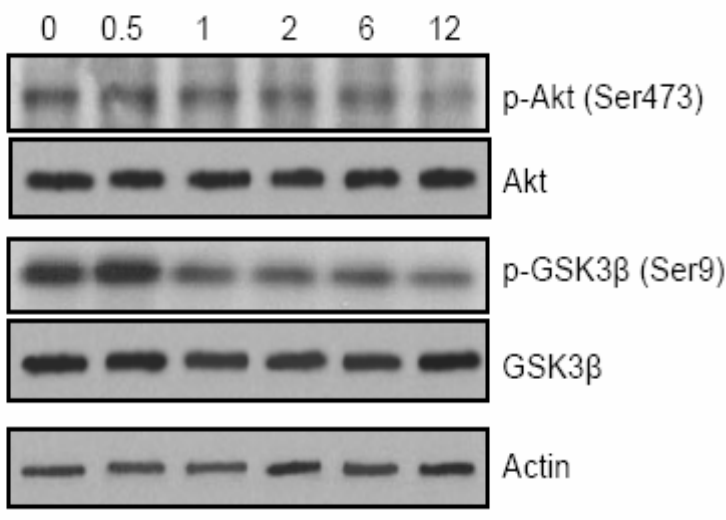


D

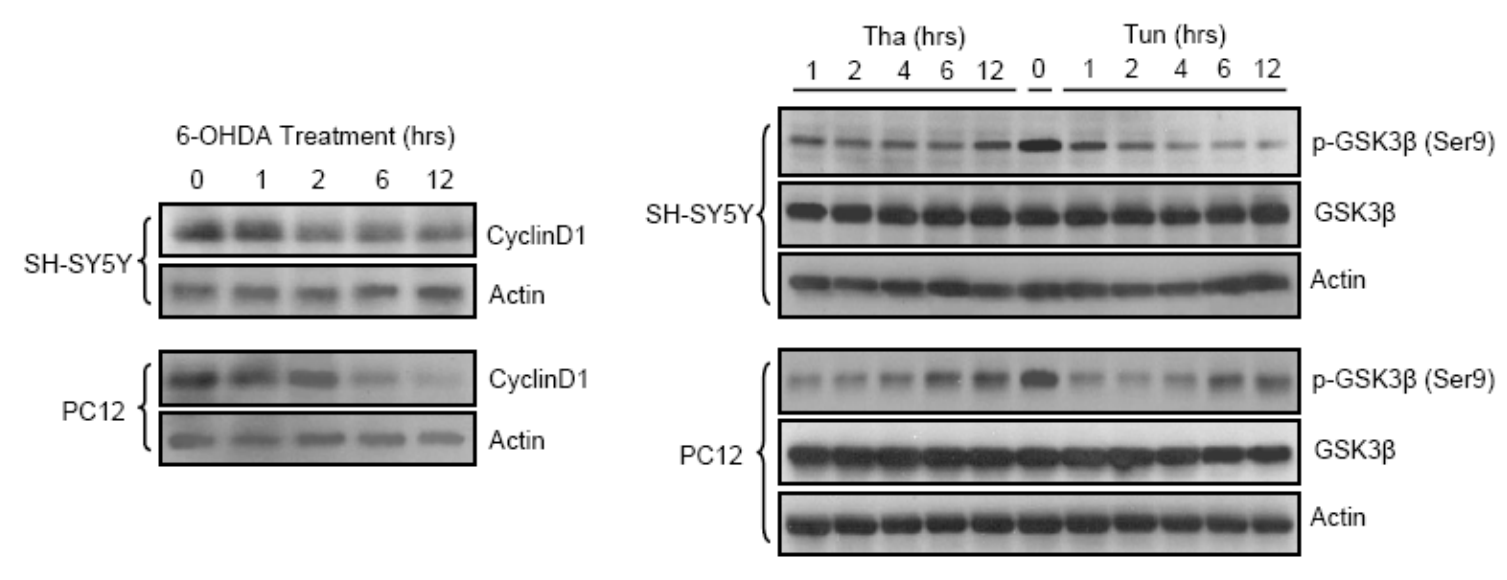


Figure 2. 3 Effect of 6-OHDA on GSK3 $\beta$, Akt and Cyclin D1

(A) SH-SY5Y cells were cultured in serum-free medium for $24 \mathrm{~h}$ and exposed to 6OHDA $(50 \mu \mathrm{M})$. Phosphorylation and expression of GSK3 $\beta$ and Akt were determined by immunoblots. The same blots were stripped and re-probed with an anti-actin antibody (Panel on the left). The relative amount of phosphorylated proteins imaged on the films was measured microdensitometrically using SigmaGel software (SPSS, Chicago IL) (Panel on the right). Each data point ( \pm SEM; bars) is the mean of three replicates. (B) PC12 cells were cultured in serum-free medium for $24 \mathrm{~h}$ and exposed to 6-OHDA (50 $\mu \mathrm{M})$. The phosphorylation and expression of GSK3 $\beta$ and Akt were determined by immunoblots. (C) Cerebellar granule neurons (CGNs) were isolated from 7-day-old rat pups, maintained in serum-free medium and exposed to 6-OHDA $(50 \mu \mathrm{M})$. Phosphorylation and expression of GSK3 $\beta$ and Akt were determined by immunoblots. (D) SH-SY5Y and PC12 cells were cultured in serum-free medium for $24 \mathrm{~h}$ and exposed to 6-OHDA $(50 \mu \mathrm{M})$. The expression of cyclin D1 was determined by immunoblots. The same blots were stripped and re-probed with an anti-actin antibody. The experiment was replicated three times. (E) SH-SY5Y and PC12 cells were treated with thapsigargin (Tha, $1 \mu \mathrm{M}$ ) or tunicamycin (Tun, $3 \mu \mathrm{g} / \mathrm{ml}$ ) for 1-12 h. Phosphorylation (Ser9) and expression of GSK3 $\beta$ were determined by immunoblots. The experiment was replicated three times. 

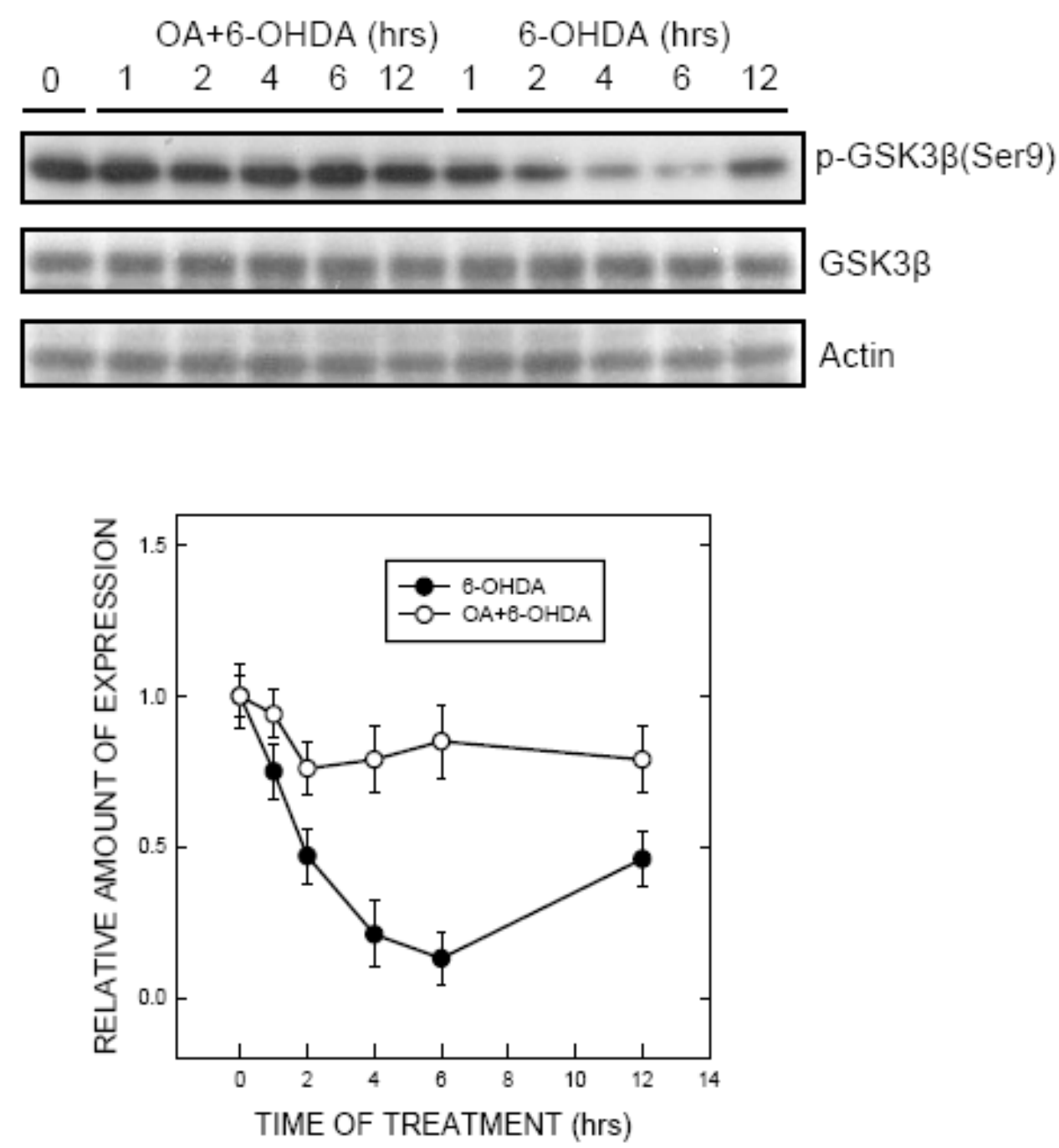

Figure 2. 4 Effect of inhibitor of PP2A/PP1 on 6-OHDA-mediated GSK3 $\beta$ dephosphorylation

SH-SY5Y cells were cultured in serum-free medium and pre-treated with a selective inhibitor of PP2A/PP1, okadaic acid (OA, 0 or $1 \mathrm{nM})$, for $30 \mathrm{~min}$. After that, cells were exposed to 6-OHDA (50 $\mu \mathrm{M})$, and phosphorylation of GSK3 $\beta$ (Ser9) was determined by immunoblots. The same blots were stripped and re-probed with an anti-actin antibody (Top panel). The relative amount of phosphorylated proteins imaged on the films was 
measured microdensitometrically (Bottom panel). The experiment was replicated three times. 
A

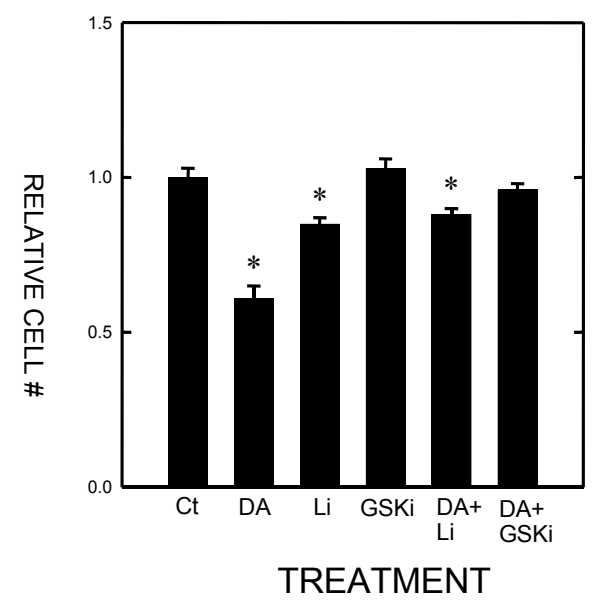

B

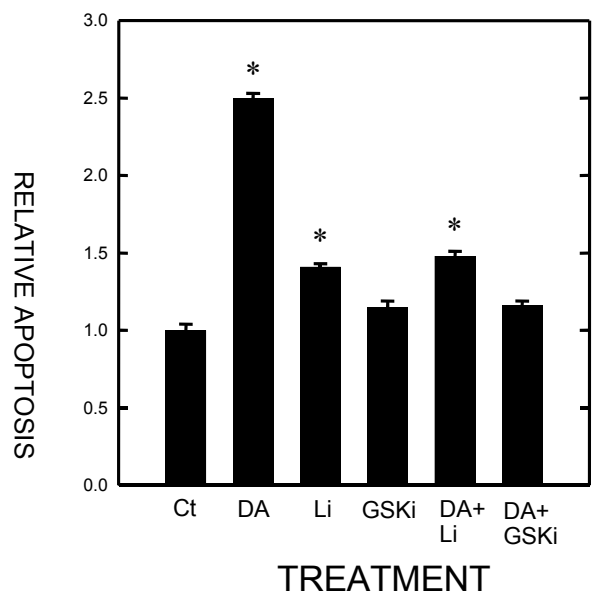




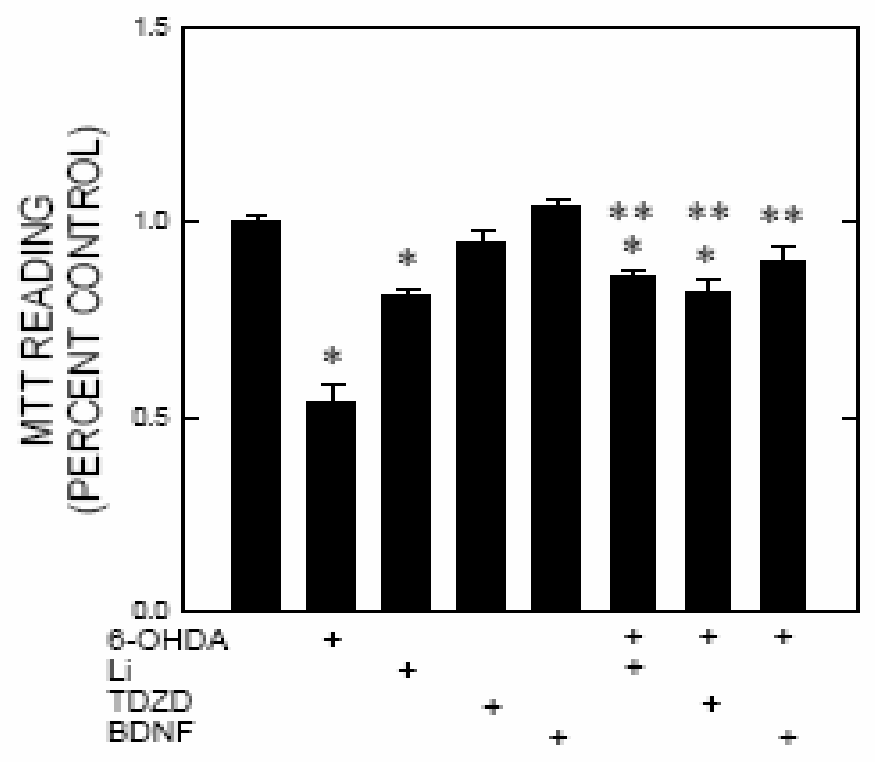

TREATMENT

E
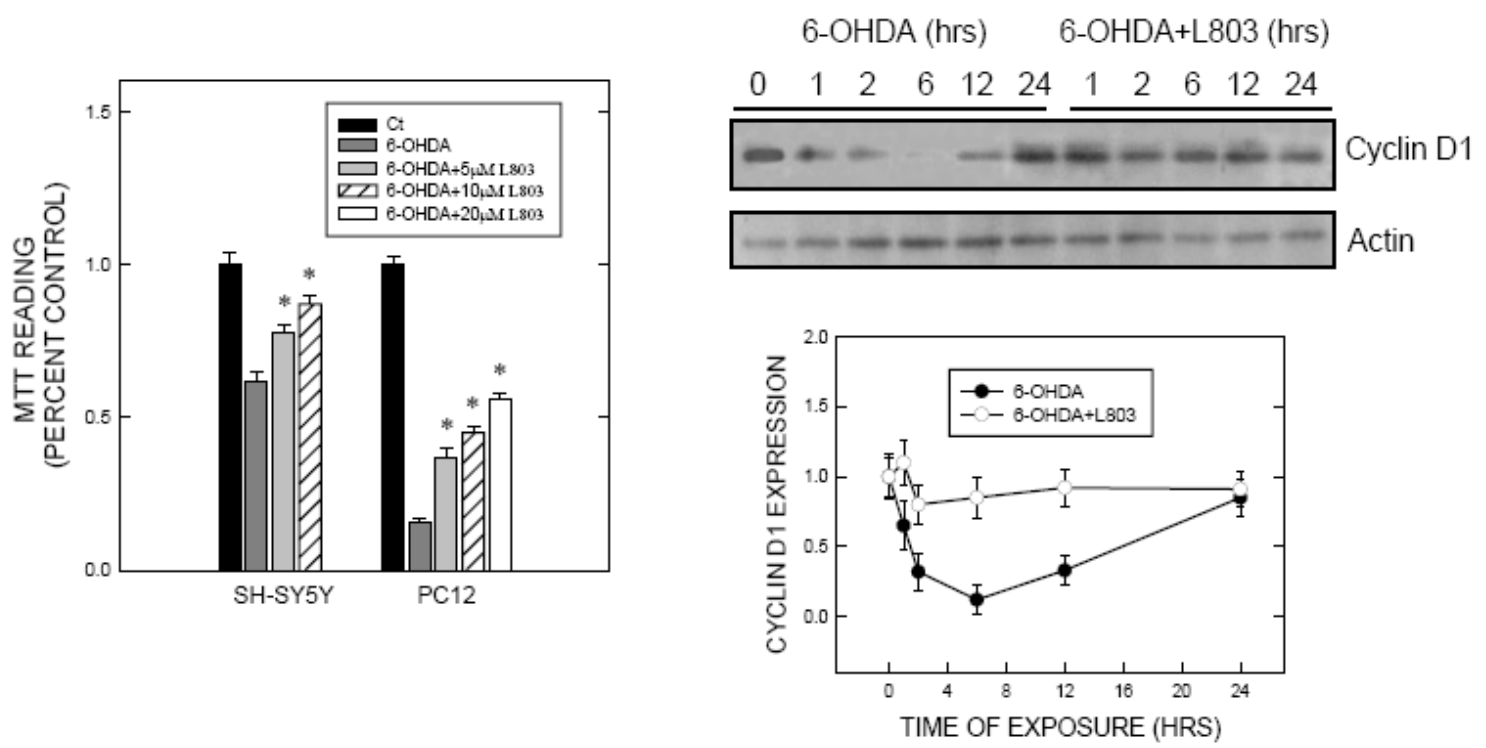
Figure 2. 5 Effect of inhibitors of GSK3 $\beta$ on 6-OHDA-mediated cell death

(A) SH-SY5Y cells were cultured in serum-free medium and pre-treated with inhibitors of GSK3 $\beta, \mathrm{LiCl}(\mathrm{Li}, 20 \mathrm{mM})$ or TDZD-8 $(10 \mu \mathrm{M})$ for $1 \mathrm{~h}$. After that, cells were exposed to 6-OHDA (DA, $50 \mu \mathrm{M}, 24 \mathrm{~h}$ ) and the numbers of viable cells were determined by the MTT assay. The amount of cells relative to the untreated control was calculated. (B) SH-SY5Y cells were similarly treated as described in (A) and relative apoptosis was determined as described in Figure 1.2. Each data point ( \pm SEM; bars) is the mean of four independent trials. $* \mathrm{p}<0.05$, statistically significant difference from untreated controls. (C) Expression of PARP and active (cleaved) caspase-3. SH-SY5Y cells were similarly treated as described in (A) and the expression of PARP and active caspase- 3 was determined as described in Figure 1.2. The experiment was replicated three times. (D) CGNs were pretreated with BDNF (100 ng/ml, $24 \mathrm{~h}$ ) or inhibitors for GSK3 $\beta$ (Li or TDZD-8, 1h). After that, cells were exposed to 6-OHDA $(50 \mu \mathrm{M})$ for $24 \mathrm{~h}$. The number of viable cells was determined with MTT assay and the amount of cells relative to the untreated control was calculated. Each data point ( \pm SEM; bars) is the mean of four independent trials. ${ }^{*} \mathrm{p}<0.05$, statistically significant difference from untreated controls. ** $\mathrm{p}<0.05$, statistically significant difference from 6-OHDA-treated groups. (E) SHSY5Y and PC12 cells were cultured in serum-free medium and pre-treated with a cellpermeable peptide inhibitor of GSK3 $\beta$ (L803-mts, 0-20 $\mu \mathrm{M}$ ) for $1 \mathrm{~h}$. After that, cells were exposed to 6-OHDA $(50 \mu \mathrm{M})$ and the number of viable cells was determined by MTT assay. Each data point ( \pm SEM; bars) is the mean of four independent trials. $* \mathrm{p}<$ 0.05, statistically significant difference from 6-OHDA only groups. (F) SH-SY5Y cells were pre-treated with L803-mts $(0$ or $15 \mu \mathrm{M})$ for $1 \mathrm{~h}$, and exposed to 6-OHDA $(50 \mu \mathrm{M})$. 
The expression of cyclin D1 was determined by immunoblots (Top panel). The same blots were stripped and re-probed with an anti-actin antibody. The relative amount of cyclin D1 was measured microdensitometrically and normalized to the expression of actin (Bottom panel). The experiment was replicated three times. 
A

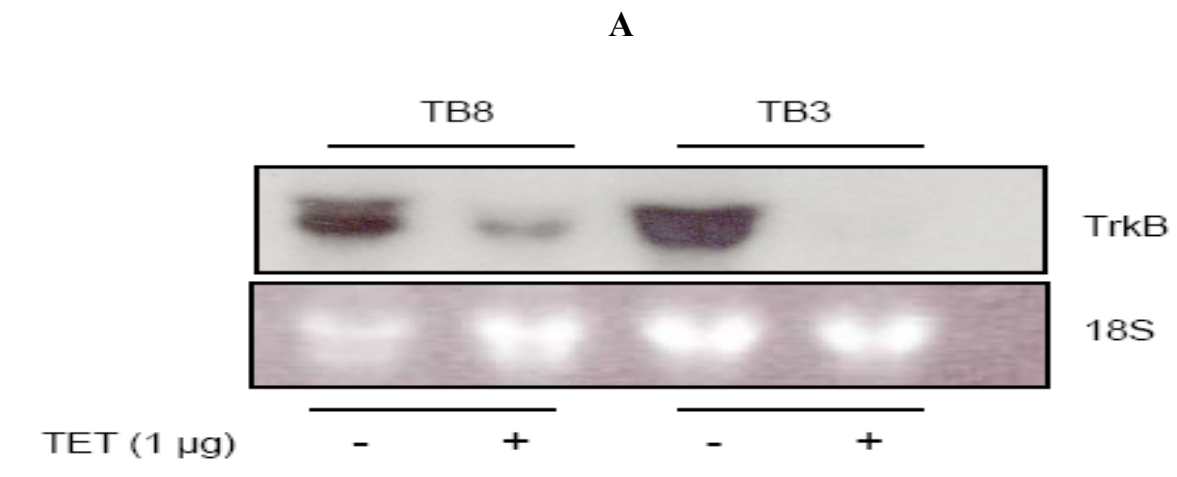

B

C
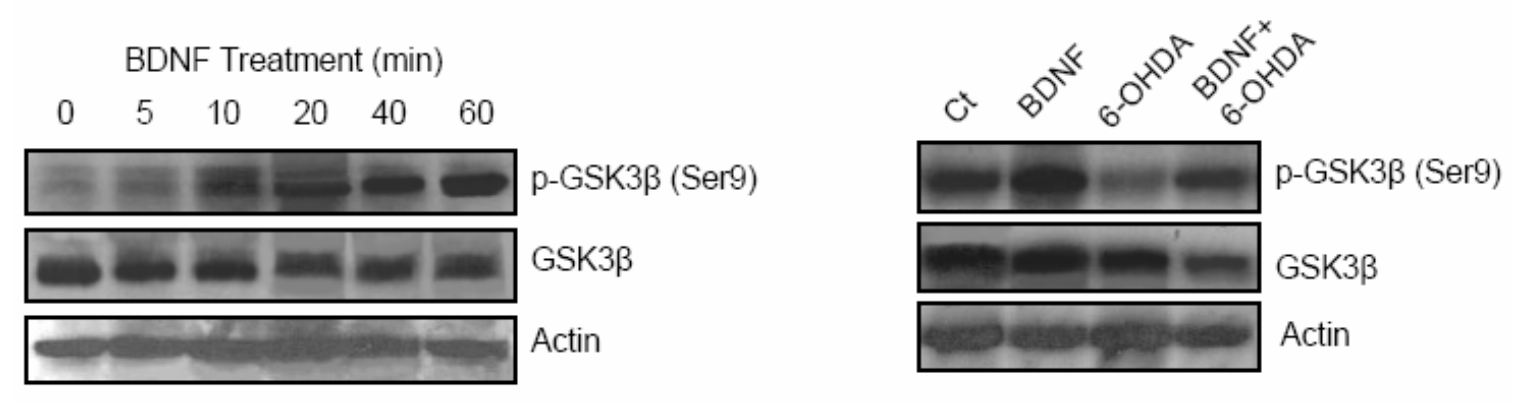

Figure 2. 6 BDNF-induced GSK3 $\beta$ phosphorylation in SH-SY5Y cells

(A) Inducible expression of TrkB in SH-SY5Y cells. TB8 and TB3 cells were cultured for 3 days in the presence or absence of Tet $(1 \mu \mathrm{g})$ in a medium containing $10 \% \mathrm{FBS}$. Total RNA was extracted, and $30 \mu \mathrm{g}$ of total RNA was electrophoresed in a $1.2 \%$ agarose/formaldehyde gel and stained with $2 \mathrm{mg} / \mathrm{ml}$ ethidium bromide. Gels were subsequently transferred to a nitrocellulose membrane, and hybridized with a ${ }^{32} \mathrm{P}$-labeled cDNA probe for TrkB. (B) BDNF induced phosphorylation of GSK3 $\beta$ at Ser9. TB8 cells expressing high levels of TrkB (Tet-off condition) were cultured in serum-free medium and exposed to BDNF (100 ng/ml). Phosphorylation and expression of GSK3 $\beta$ were determined with immunoblots. The same blots were stripped and re-probed with an 
anti-actin antibody. (C) Counteracting 6-OHDA's effect by BDNF. TB8 cells maintained in a Tet-off condition were pre-treated with BDNF (0 or $100 \mathrm{ng} / \mathrm{ml}$ ) for $24 \mathrm{~h}$. After pre-treatment, cells were exposed to 6-OHDA $(50 \mu \mathrm{M})$ with/without BDNF for $2 \mathrm{~h}$. Phosphorylation and expression of GSK $3 \beta$ were determined by immunoblots. 
A

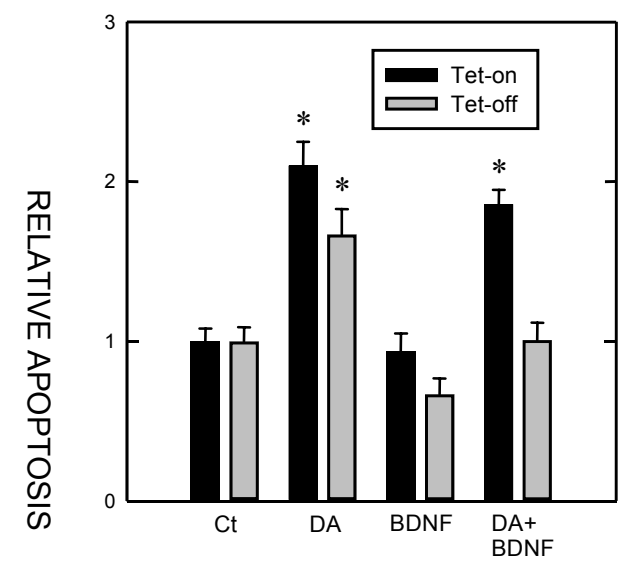

B

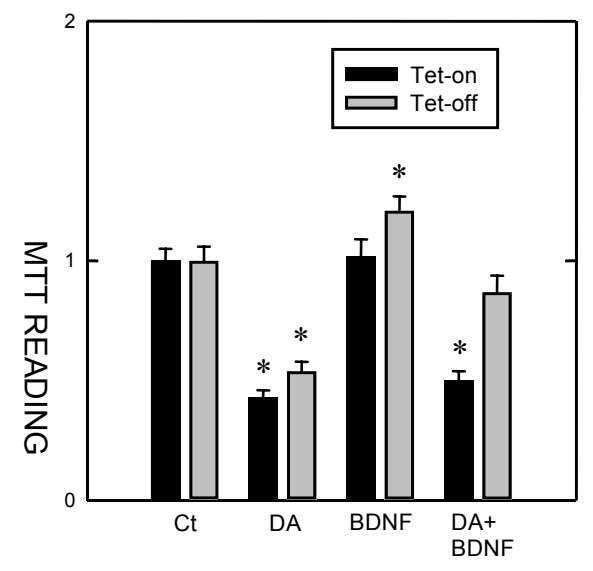

Figure 2. 7 Effect of TrkB activation on 6-OHDA-mediated cell death

TB8 cells were cultured for 3 days in the presence or absence of Tet (Tet-on or Tet-off, 1 $\mu \mathrm{g})$. Cells were then pre-treated with BDNF (0 or $100 \mathrm{ng} / \mathrm{ml}$ ) for $24 \mathrm{~h}$ and exposed to 6OHDA (DA, $50 \mu \mathrm{M}$ ) for an additional $24 \mathrm{~h}$. Relative apoptosis (A) and the number of viable cells (B) were determined as described in Figure 2. Each data point ( \pm SEM; bars) is the mean of four independent trials. $* \mathrm{p}<0.05$, statistically significant difference from paired, untreated controls. 

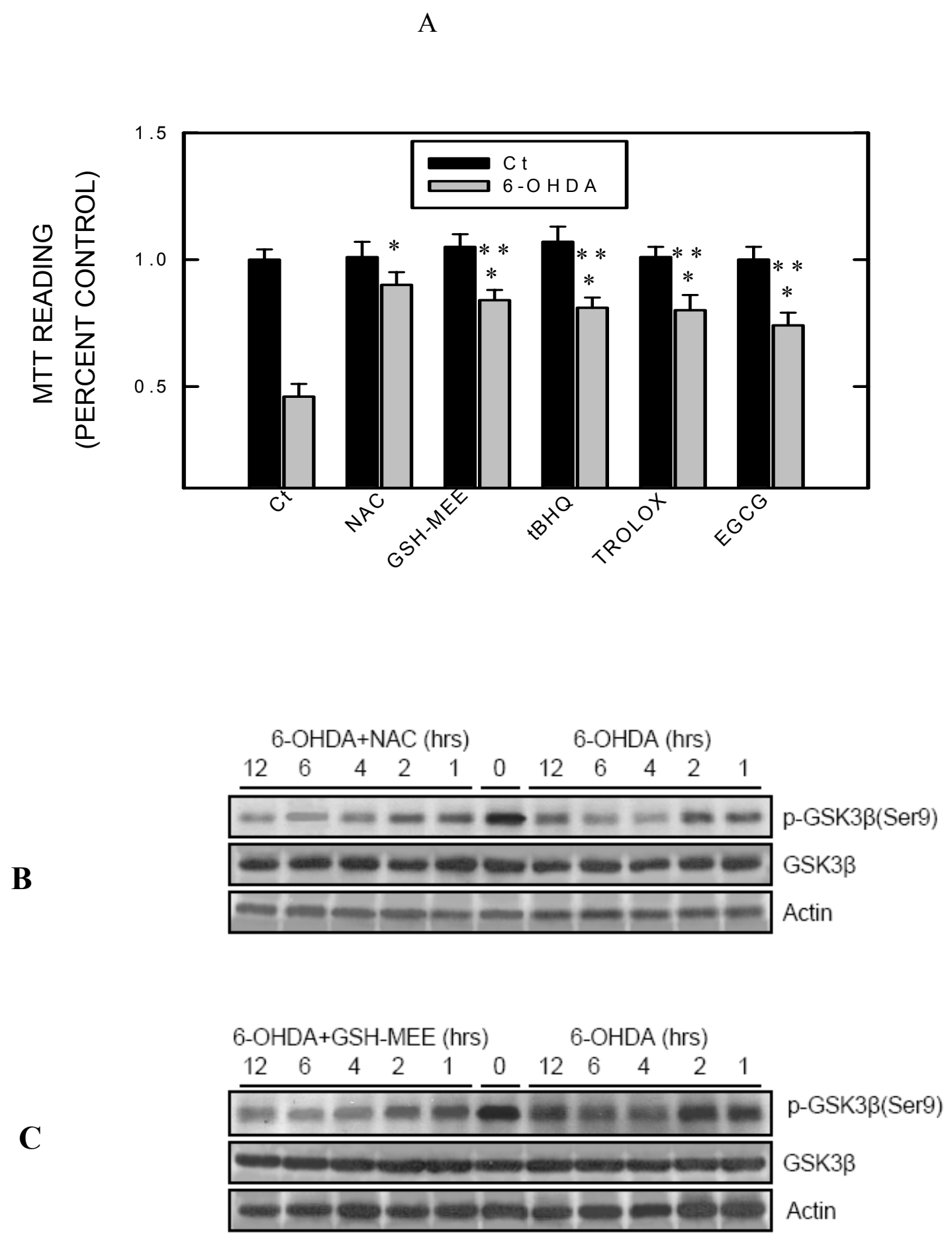
Figure 2. 8 Effect of antioxidants on 6-OHDA-induced cell death and GSK3 $\beta$ dephosphorylation

(A) SH-SY5Y cells grown in serum-free medium were pre-treated with various antioxidants for $30 \mathrm{~min}$, and exposed to 6-OHDA $(50 \mu \mathrm{M})$ for $24 \mathrm{~h}$. Cell viability was analyzed with MTT assay. The experiment was replicated four times. $* \mathrm{p}<0.05$, statistically significant difference from 6-OHDA-treated but no antioxidant-exposed groups. $* * \mathrm{p}<0.05$, statistically significant difference from paired, antioxidant-treated but no 6-OHDA-exposed groups. NAC ( $N$-acetylcysteine, $10 \mathrm{mM})$; GSH-MEE (glutathione monoethyl ester, $8 \mathrm{mM}$ ); tBHQ (tert-butylhydroquinone, $40 \mu \mathrm{M}$ ); Trolox (10 $\mu \mathrm{M})$; EGCG [(-)-Epigallocatechin gallate, $1 \mu \mathrm{M}]$; Ct (control, $\mathrm{ddH}_{2} \mathrm{O}$ ). (B, C) SH-SY5Y cells grown in serum-free medium were pre-treated with NAC (223) or GSH-MEE (8 $\mathrm{mM}$ ) for $30 \mathrm{~min}$, and exposed to 6-OHDA $(50 \mu \mathrm{M})$. Phosphorylation (Ser9) and expression of GSK3 $\beta$ were determined by immunoblots. The experiment was replicated three times. 


\section{Reference List}

1. Mattson, M. P., LaFerla, F. M., Chan, S. L., Leissring, M. A., Shepel, P. N., and Geiger, J. D. (2000) Calcium signaling in the ER: its role in neuronal plasticity and neurodegenerative disorders. Trends Neurosci. 23, 222-9

2. Paschen, W., and Frandsen, A. (2001) Endoplasmic reticulum dysfunction--a common denominator for cell injury in acute and degenerative diseases of the brain? J. Neurochem. 79, 719-25

3. Sherman, M. Y., and Goldberg, A. L. (2001) Cellular defenses against unfolded proteins: a cell biologist thinks about neurodegenerative diseases. Neuron 29, 15 32

4. Mattson, M. P., Guo, Q., Furukawa, K., and Pedersen, W. A. (1998) Presenilins, the endoplasmic reticulum, and neuronal apoptosis in Alzheimer's disease. $J$. Neurochem. 70, 1-14

5. Nakagawa, T., Zhu, H., Morishima, N., Li, E., Xu, J., Yankner, B. A., and Yuan, J. (2000) Caspase-12 mediates endoplasmic-reticulum-specific apoptosis and cytotoxicity by amyloid-beta. Nature 403, 98-103

6. Shimura, H., Hattori, N., Kubo, S., Mizuno, Y., Asakawa, S., Minoshima, S., Shimizu, N., Iwai, K., Chiba, T., Tanaka, K., and Suzuki, T. (2000) Familial Parkinson disease gene product, parkin, is a ubiquitin-protein ligase. Nat. Genet. $25,302-5$

7. Imai, Y., Soda, M., Inoue, H., Hattori, N., Mizuno, Y., and Takahashi, R. (2001) An unfolded putative transmembrane polypeptide, which can lead to endoplasmic reticulum stress, is a substrate of Parkin. Cell 105, 891-902

8. Shastry, B. S. (2002) Therapeutic options for Parkinson's disease. Drugs Today (Barc) 38, 445-51

9. Warner, T. T., Schapira, A. H. (2003) Genetic and environmental factors in the cause of Parkinson's disease. Ann. Neurol. 53, S16-23

10. Betarbet, R., Sherer, T. B., Di Monte, D. A., and Greenamyre, J. T. (2002) Mechanistic approaches to Parkinson's disease pathogenesis. Brain Pathol. 12, 499-510

11. Di Matteo, V., and Esposito, E. (2003) Biochemical and therapeutic effects of antioxidants in the treatment of Alzheimer's disease, Parkinson's disease, and amyotrophic lateral sclerosis. Curr. Drug Target CNS Neurol. Disord. 2, 95-107

12. Jenner, P. (2003) Oxidative stress in Parkinson's disease. Ann. Neurol. 53, S26-36

13. Ryu, E. J., Harding, H. P., Angelastro, J. M., Vitolo, O. V., Ron, D., and Greene, L. A. (2002) Endoplasmic reticulum stress and the unfolded protein response in cellular models of Parkinson's disease. J. Neurosci. 22, 10690-8 
14. Holtz, W. A., and O'Malley, K. L. (2003) Parkinsonian mimetics induce aspects of unfolded protein response in death of dopaminergic neurons. J. Biol. Chem. 278, 19367-77

15. Choi, W. S., Yoon, S. Y., Oh, T. H., Choi, E. J., O'Malley, K. L., and Oh, Y. J. (1999) Two distinct mechanisms are involved in 6-hydroxydopamine- and MPP+induced dopaminergic neuronal cell death: role of caspases, ROS, and JNK. $J$. Neurosci. Res. 57, 86-94

16. Storch, A., Burkhardt, K., Ludolph, A. C., and Schwarz, J. (2000) Protective effects of riluzole on dopamine neurons: involvement of oxidative stress and cellular energy metabolism. J. Neurochem. 75, 2259-69

17. Hou, S. T., Cowan, E., Walker, T., Ohan, N., Dove, M., Rasqinha, I., and MacManus, J. P. (2001) The transcription factor E2F1 promotes dopamineevoked neuronal apoptosis by a mechanism independent of transcriptional activation. J. Neurochem. 78, 287-97

18. von Coelln, R., Kugler, S., Bahr, M., Weller, M., Dichgans, J., and Schulz, J. B. (2001) Rescue from death but not from functional impairment: caspase inhibition protects dopaminergic cells against 6-hydroxydopamine-induced apoptosis but not against the loss of their terminals. J. Neurochem. 77, 263-73

19. Linert, W., Herlinger, E., Jameson, R. F., Kienzl, E., Jellinger, K., and Youdim, M. B. (1996) Dopamine, 6-hydroxydopamine, iron, and dioxygen--their mutual interactions and possible implication in the development of Parkinson's disease. Biochim. Biophys. Acta. 1316, 160-8

20. Curtius, H. C., Wolfensberger, M., Steinmann, B., Redweik, U., and Siegfried, J. (1974) Mass fragmentography of 5-hydroxytryptophol and 5-methoxytryptophol in human cerebrospinal fluid. J. Chromatogr. 99, 529-40

21. Andrew, R., Watson, D. G., Best, S. A., Midgley, J. M., Wenlong, H., and Petty, R. K. (1993) The determination of hydroxydopamines and other trace amines in the urine of parkinsonian patients and normal controls. Neurochem. Res. 18, $1175-7$

22. Spencer, J. P., Jenner, P., Daniel, S. E., Lees, A. J., Marsden, D. C., and Halliwell, B. (1998) Conjugates of catecholamines with cysteine and GSH in Parkinson's disease: possible mechanisms of formation involving reactive oxygen species. $J$. Neurochem. 71, 2112-22

23. Takahashi, T., Deng, Y., Maruyama, W., Dostert, P., Kawai, M., and Naoi, M. (1994) Uptake of a neurotoxin-candidate, (R)-1,2-dimethyl-6,7-dihydroxy1,2,3,4-tetrahydroisoquinoline into human dopaminergic neuroblastoma SHSY5Y cells by dopamine transport system. J. Neural Transm. Gen. Sect. 98, 10718

24. Jaboin, J., Kim, C. J., Kaplan, D. R., and Thiele, C. J. (2002) Brain-derived neurotrophic factor activation of TrkB protects neuroblastoma cells from chemotherapy-induced apoptosis via phosphatidylinositol 3'-kinase pathway. Cancer Res. 62, 6756-63 
25. Dodel, R. C., Du, Y., Bales, K. R., Ling, Z., Carvey, P. M., and Paul, S. M. (1999) Caspase-3-like proteases and 6-hydroxydopamine induced neuronal cell death. Brain Res. Mol. Brain Res. 64, 141-8

26. Daily, D., Vlamis-Gardikas, A., Offen, D., Mittelman, L., Melamed, E., Holmgren, A., and Barzilai, A. (2001) Glutaredoxin protects cerebellar granule neurons from dopamine-induced apoptosis by dual activation of the rasphosphoinositide 3-kinase and jun n-terminal kinase pathways. J. Biol. Chem. 276, 21618-26

27. Lin, S., Wei, X., Xu, Y., Yan, C., Dodel, R., Zhang, Y., Liu, J., Klaunig, J. E., Farlow, M., and Du, Y. (2003) Minocycline blocks 6-hydroxydopamine-induced neurotoxicity and free radical production in rat cerebellar granule neurons. Life Sci. 72, 1635-41

28. Luo, J., West, J. R., and Pantazis, N. J. (1997) Nerve growth factor and basic fibroblast growth factor protect rat cerebellar granule cells in culture against ethanol-induced cell death. Alcohol Clin. Exp. Res. 21, 1108-20

29. Li, Z., Lin, H., Zhu, Y., Wang, M., and Luo, J. (2001) Disruption of cell cycle kinetics and cyclin-dependent kinase system by ethanol in cultured cerebellar granule progenitors. Brain Res. Dev. Brain Res. 132, 47-58

30. Sun, Y., Lin, H., Zhu, Y., Ma, C., Ye, J., and Luo, J. (2002) Induction or suppression of expression of cytochrome $\mathrm{C}$ oxidase subunit II by heregulin beta 1 in human mammary epithelial cells is dependent on the levels of ErbB2 expression. J. Cell Physiol. 192, 225-33

31. Luo, J., Sun, Y., Lin, H., Qian, Y., Li, Z., Leonard, S. S., Huang, C., and Shi, X. (2003) Activation of JNK by vanadate induces a Fas-associated death domain (FADD)-dependent death of cerebellar granule progenitors in vitro. J. Biol. Chem. $278,4542-51$

32. Thiele, C. J., Cohen, P. S., and Israel, M. A. (1988) Regulation of c-myb expression in human neuroblastoma cells during retinoic acid-induced differentiation. Mol. Cell Biol. 8, 1677-83

33. Kim, C. J., Matsuo, T., Lee, K. H., and Thiele, C. J. (1999) Up-regulation of insulin-like growth factor-II expression is a feature of TrkA but not TrkB activation in SH-SY5Y neuroblastoma cells. Am. J. Pathol. 155, 1661-70

34. Luo, J., and Miller, M. W. (1999) Platelet-derived growth factor-mediated signal transduction underlying astrocyte proliferation: site of ethanol action. $J$. Neurosci. 19, 10014-25

35. McCullough, K. D., Martindale, J. L., Klotz, L. O., Aw, T. Y., and Holbrook, N. J. (2001) Gadd153 sensitizes cells to endoplasmic reticulum stress by downregulating Bcl2 and perturbing the cellular redox state. Mol. Cell Biol. 21, 124959

36. Rao, R. V., Peel, A., Logvinova, A., del Rio, G., Hermel, E., Yokota, T., Goldsmith, P. C., Ellerby, L. M., Ellerby, H. M., and Bredesen, D. E. (2002) 
Coupling endoplasmic reticulum stress to the cell death program: role of the ER chaperone GRP78. FEBS Lett. 514, 122-8

37. Mandic, A., Hansson, J., Linder, S., and Shoshan, M. C. (2003) Cisplatin induces endoplasmic reticulum stress and nucleus-independent apoptotic signaling. $J$. Biol. Chem. 278, 9100-6

38. Morishima, N., Nakanishi, K., Takenouchi, H., Shibata, T., and Yasuhiko, Y. (2002) An endoplasmic reticulum stress-specific caspase cascade in apoptosis. Cytochrome c-independent activation of caspase-9 by caspase-12. J. Biol. Chem. 277, 34287-94

39. Song, L., De Sarno, P., and Jope, R. S. (2002) Central role of glycogen synthase kinase-3beta in endoplasmic reticulum stress-induced caspase-3 activation. $J$. Biol. Chem. 277, 44701-8

40. Reimertz, C., Kogel, D., Rami, A., Chittenden, T., and Prehn, J. H. (2003) Gene expression during ER stress-induced apoptosis in neurons: induction of the BH3only protein Bbc3/PUMA and activation of the mitochondrial apoptosis pathway. J. Cell Biol. 162, 587-97

41. Thastrup, O., Cullen, P. J., Drobak, B. K., Hanley, M. R., and Dawson, A. P. (1990) Thapsigargin, a tumor promoter, discharges intracellular Ca2+ stores by specific inhibition of the endoplasmic reticulum Ca2(+)-ATPase. Proc. Natl. Acad. Sci. U. S. A. 87, 2466-70

42. Kaytor, M. D., and Orr, H. T. (2002) The GSK3 beta signaling cascade and neurodegenerative disease. Curr. Opin. Neurobiol. 12, 275-8

43. Grimes, C. A., and Jope, R. S. (2001) The multifaceted roles of glycogen synthase kinase 3beta in cellular signaling. Prog. Neurobiol. 65, 391-426

44. Diehl, J.A., Zindy, F., and Sherr, C.J. (1997) Inhibition of cyclin D1 phosphorylation on threonine-286 prevents its rapid degradation via the ubiquitinproteasome pathway. Genes Dev. 11, 957-972

45. Diehl, J.A., Cheng, M., Roussel, M.F., and Sherr, C.J. (1998) Glycogen synthase kinase-3beta regulates cyclin D1 proteolysis and subcellular localization. Genes Dev. 12, 3499-3511

46. Ivaska J, Nissinen L, Immonen N, Eriksson JE, Kahari VM, Heino J. (2002) Integrin alpha 2 beta 1 promotes activation of protein phosphatase $2 \mathrm{~A}$ and dephosphorylation of Akt and glycogen synthase kinase 3 beta. Mol Cell Biol. 22, 1352-9.

47. Martinez, A., Alonso, M., Castro, A., Perez, C., and Moreno, F. J. (2002) First non-ATP competitive glycogen synthase kinase 3 beta (GSK-3beta) inhibitors: thiadiazolidinones (TDZD) as potential drugs for the treatment of Alzheimer's disease. J. Med. Chem. 45, 1292-9

48. Plotkin, B., Kaidanovich, O., Talior, I., and Eldar-Finkelman, H. (2003) Insulin mimetic action of synthetic phosphorylated peptide inhibitors of glycogen synthase kinase-3. J. Pharmacol. Exp. Ther. 305, 974-980. 
49. Patapoutian, A., and Reichardt, L. F. (2001) Trk receptors: mediators of neurotrophin action. Curr. Opin. Neurobiol. 11, 272-80

50. Ho, R., Eggert, A., Hishiki, T., Minturn, J. E., Ikegaki, N., Foster, P., Camoratto, A. M., Evans, A. E., and Brodeur, G. M. (2002) Resistance to chemotherapy mediated by TrkB in neuroblastomas. Cancer Res. 62, 6462-6

51. Courtney, M. J., Akerman, K. E., and Coffey, E. T. (1997) Neurotrophins protect cultured cerebellar granule neurons against the early phase of cell death by a twocomponent mechanism. J. Neurosci. 17, 4201-11

52. Frame, S., and Cohen, P. (2001) GSK3 takes centre stage more than 20 years after its discovery. Biochem. J. 359, 1-16

53. Leroy, K., and Brion, J. P. (1999) Developmental expression and localization of glycogen synthase kinase-3beta in rat brain. J. Chem. Neuroanat. 16, 279-93

54. Meier, R., Thelen, M., and Hemmings, B. A. (1998) Inactivation and dephosphorylation of protein kinase Balpha (PKBalpha) promoted by hyperosmotic stress. EMBO J. 17, 7294-303

55. Hartigan, J. A., and Johnson, G. V. (1999) Transient increases in intracellular calcium result in prolonged site-selective increases in Tau phosphorylation through a glycogen synthase kinase 3beta-dependent pathway. J. Biol. Chem. 274, 21395-401

56. Lesort, M., Jope, R. S., and Johnson, G. V. (1999) Insulin transiently increases tau phosphorylation: involvement of glycogen synthase kinase-3beta and Fyn tyrosine kinase. J. Neurochem. 72, 576-84

57. Sutherland, C., Leighton, I. A., and Cohen, P. (1993) Inactivation of glycogen synthase kinase-3 beta by phosphorylation: new kinase connections in insulin and growth-factor signalling. Biochem. J. 296, 15-9

58. Welsh, G. I., and Proud, C. G. (1993) Glycogen synthase kinase-3 is rapidly inactivated in response to insulin and phosphorylates eukaryotic initiation factor eIF-2B. Biochem. J. 294, 625-9

59. Andjelkovic, M., Jakubowicz, T., Cron, P., Ming, X. F., Han, J. W., and Hemmings, B. A. (1996) Activation and phosphorylation of a pleckstrin homology domain containing protein kinase (RAC-PK/PKB) promoted by serum and protein phosphatase inhibitors. Proc. Natl. Acad. Sci. U. S. A. 93, 5699-704

60. Frei, B., and Richter, C. (1986) N-methyl-4-phenylpyridine (MMP+) together with 6-hydroxydopamine or dopamine stimulates $\mathrm{Ca} 2+$ release from mitochondria. FEBS Lett. 198, 99-102

61. Youdim, M. B., and Riederer, P. (1993) The role of iron in senescence of dopaminergic neurons in Parkinson's disease. J. Neural Transm. Suppl. 40, 57-67

62. Tsuboi, K., Kimber, T. A., and Shults, C. W. (2000) Calretinin-containing axons and neurons are resistant to an intrastriatal 6-hydroxydopamine lesion. Brain Res. $866,55-64$ 
63. Kaufman, R. J. (1999) Stress signaling from the lumen of the endoplasmic reticulum: coordination of gene transcriptional and translational controls. Genes Dev. 13, 1211-33

64. Stokes, A. H., Hastings, T. G., and Vrana, K. E. (1999) Cytotoxic and genotoxic potential of dopamine. J. Neurosci. Res. 55, 659-65

65. Crowder, R. J., and Freeman, R. S. (2000) Glycogen synthase kinase-3 beta activity is critical for neuronal death caused by inhibiting phosphatidylinositol 3kinase or Akt but not for death caused by nerve growth factor withdrawal. J. Biol. Chem. 275, 34266-71

66. Hetman, M., Cavanaugh, J. E., Kimelman, D., and Xia, Z. (2000) Role of glycogen synthase kinase-3beta in neuronal apoptosis induced by trophic withdrawal. J. Neurosci. 20, 2567-74

67. Lucas, J. J., Hernandez, F., Gomez-Ramos, P., Moran, M. A., Hen, R., and Avila, J. (2001) Decreased nuclear beta-catenin, tau hyperphosphorylation and neurodegeneration in GSK-3beta conditional transgenic mice. EMBO J. 20, 27-39

68. Bhat, R. V., and Budd, S. L. (2002) GSK3beta signalling: casting a wide net in Alzheimer's disease. Neurosignals 11, 251-61

69. Bijur, G. N., and Jope, R. S. (2001) Proapoptotic stimuli induce nuclear accumulation of glycogen synthase kinase-3 beta. J. Biol. Chem. 276, 3743637442

70. Cohen G, Heikkila RE. (1974) The generation of hydrogen peroxide, superoxide radical, and hydroxyl radical by 6-hydroxydopamine, dialuric acid, and related cytotoxic agents. $J$ Biol Chem. 249, 2447-2452.

71. Choi WS, Yoon SY, Oh TH, Choi EJ, O'Malley KL, Oh YJ. (1999) Two distinct mechanisms are involved in 6-hydroxydopamine- and MPP+-induced dopaminergic neuronal cell death: role of caspases, ROS, and JNK. J Neurosci Res. 57, 86-94.

72. Soto-Otero R, Mendez-Alvarez E, Hermida-Ameijeiras A, Munoz-Patino AM, Labandeira-Garcia JL. (2000) Autoxidation and neurotoxicity of 6hydroxydopamine in the presence of some antioxidants: potential implication in relation to the pathogenesis of Parkinson's disease. J Neurochem. 74, 1605-1612.

73. Elkon H, Melamed E, Offen D. (2001) 6-Hydroxydopamine increases ubiquitinconjugates and protein degradation: implications for the pathogenesis of Parkinson's disease. Cell Mol Neurobiol. 21, 771-781.

74. Levites Y, Amit T, Youdim MB, Mandel S. (2002) Involvement of protein kinase $\mathrm{C}$ activation and cell survival/ cell cycle genes in green tea polyphenol (-)epigallocatechin 3-gallate neuroprotective action. J Biol Chem. 277, 3057430580 .

75. Hara H, Ohta M, Ohta K, Kuno S, Adachi T. (2003) Increase of antioxidative potential by tert-butylhydroquinone protects against cell death associated with 6 - 
hydroxydopamine-induced oxidative stress in neuroblastoma SH-SY5Y cells. Brain Res Mol Brain Res. 119, 125-131.

76. Glazner, G.W., Mu, X., and Springer, J.E. (1998) Localization of glial cell linederived neurotrophic factor receptor alpha and c-ret mRNA in rat central nervous system. J. Comp. Neurol. 391, 42-49

77. Sarabi, A., Chang, C.F., Wang, Y., Hoffer, B.J., and Morales, M. (2001) Time course study of GFRalpha-1 expression in an animal model of stroke. Exp. Neurol. 170, 283-289

78. Neff, F., Noelker, C., Eggert, K., and Schlegel, J. (2002) Signaling pathways mediate the neuroprotective effects of GDNF. Ann. N. Y. Acad. Sci. 973, 70-74

79. Ugarte, S.D., Lin, E., Klann, E., Zigmond, M.J., and Perez R.G. (2003) Effects of GDNF on 6-OHDA-induced death in a dopaminergic cell line: modulation by inhibitors of PI3 kinase and MEK. J. Neurosci. Res. 73, 105-112

80. Dechant, G. (2001) Molecular interactions between neurotrophin receptors. Cell Tissue Res. 305, 229-238

81. Miller, F. D., and Kaplan, D. R. (2001) Neurotrophin signalling pathways regulating neuronal apoptosis. Cell Mol. Life Sci. 58, 1045-1053

82. Foulstone, E. J., Tavare, J. M., and Gunn-Moore, F. J. (1999) Sustained phosphorylation and activation of protein kinase B correlates with brain-derived neurotrophic factor and insulin stimulated survival of cerebellar granule cells. Neurosci. Lett. 264, 125-128

83. Benisty, S., Boissiere, F., Faucheux, B., Agid, Y., and Hirsch E.C. (1998) trkB messenger RNA expression in normal human brain and in the substantia nigra of parkinsonian patients: an in situ hybridization study. Neuroscience 86, 813-826

84. Nishio, T., Furukawa, S., Akiguchi, I., and Sunohara N. (1998) Neutrophin switching in spinal motoneurons of amyotrophic lateral sclerosis. Neuroreport 9 , 2847-2851

85. Hynes, M.A., Poulsen, K., Armanini, M., Berkemeier, L., Phillips, H., and Rosenthal, A. (1994) Neurotrophin-4/5 is a survival factor for embryonic midbrain dopaminergic neurons in enriched cultures. J. Neurosci. Res. 37, 144154

86. Volpe, B.T., Wildmann, J., and Altar, C.A. (1998) Brain-derived neurotrophic factor prevents the loss of nigral neurons induced by excitotoxic striatal-pallidal lesions. Neuroscience 83, 741-748 
Chapter Three: The Mechanism of Ethanol-induced Protein Synthesis

Inhibition in Cerebellar Granule Cells 


\begin{abstract}
Early developmental exposure to ethanol causes profound damage to the cerebellum, specifically significant reduction in cerebellar volume, weight and protein content. PACT (Rax) / PKR / eIF2 $\alpha$ is an important signal transducting pathway which controls the protein synthesis initiation response to different stimuli. Previous studies have shown that ethanol exposure decreases the protein content in rat cerebellum and inhibits protein synthesis initiation in rat heart, liver and skeletal muscle. Here we demonstrate that the expressions of PACT (Rax) / PKR / eIF2 $\alpha$ are developmentally regulated in rat cerebellum as ethanol exposure promotes the association of PACT (Rax) with PKR. Ethanol-induced interaction between PACT (Rax) and PKR leads to phosphorylation of eIF $2 \alpha$ and protein synthesis initiation inhibition. This inhibition can be enhanced by the over-expression of PACT (Rax). The effect of ethanol can be reversed by a mutated PACT (Rax) gene at serine 18 or PKR inhibitors. Our results provide a novel insight into the molecular mechanism for ethanol toxicity.
\end{abstract}




\section{Introduction}

Ethanol is wildly known as a teratogen (1-3); early exposure to ethanol will cause a variety of behavioral and neural abnormalities (4-6). In some cases of pregnant women, heavy chronic ethanol consumption during fetus central nervous system (CNS) causes fetal alcohol syndrome (FAS) characterized by microcephaly (7), facial dysmorphology (8), growth retardation (9) and a number of CNS abnormalities (10-12) in newborns. The developing cerebellum is one of the most vulnerable regions to ethanol in both humans and animals $(13 ; 14)$. Numerous animal model systems have been used to characterize this kind of CNS abnormality. One of these studies showed that growth of the rat brain, but not body growth, was decreased and the cerebellar was inhibited twice as much compared with the rest of the brain after exposure to ethanol (15). Other studies showed that ethanol exposure in rat pups led to significant reduction in cerebellar volume, weight (16) and protein content (17). The molecular mechanism(s) for ethanol's involvement in decreased cerebellum size and inhibition of protein synthesis has not been fully elucidated.

Previous work has determined that ethanol exposure decreased protein synthesis in rat heart (18;19), liver (20) and skeletal muscle (21), as well as in rabbit reticulocytes (22). Furthermore, ethanol-induced protein synthesis inhibition occurs by blocking the ternary complex formation among eIF2 $\alpha$, GTP and initiator Met-tRNA in protein synthesis initiation, rather than by alterations in availability of amino acids or abundance of ribosomes (23). The phosphorylation of eIF2 $\alpha$ can be increased up to $90 \%$ in rat hepatic cells after ethanol treatment (24). However, the signal transduction pathway(s) that lead to inhibition of the protein synthesis initiation and eIF $2 \alpha$ phosphorylation remain unclear. 
Double-stranded RNA (dsRNA) activated protein kinase (PKR) is a serine/threonine protein kinase and is ubiquitously expressed in mammalian cells. It contains 551 amino acids in humans and 515 in mice $(25 ; 26)$. PKR consists of two functionally distinct domains: an N-terminal dsRNA binding regulatory domain and the C-terminal catalytic domain (27-31). PKR is initially identified as an interferon-induced protein that is activated in virus-infected cells by double-stranded RNA produced during the virus life cycle (32;33). Recently it has been clear that PKR is a component of signal transduction pathways mediating important cellular functions such as growth control, proliferation, differentiation and stress response (34-36). PKR can be activated by dsRNA, cytokines (37), growth factor, serum deprivation, bacterial products or physiochemical stress $(38 ; 39)$. A pair of dsRNA binding motifs located in the N-terminal domain of PKR act as a sensor to bind dsRNA or protein activators (which themselves contain dsRNA binding domains) (40). The known protein activators of PKR include PACT (PKR-activating protein) (41-43) and its mouse homologue Rax (44). PACT/Rax is also a ubiquitously expressed mammalian protein which is phosphorylated at serine 18 following stress; it heterodimerizes with PKR and activates it in absence of dsRNA (45). Serine 18 of PACT/Rax is a crucial phosphorylation site for activation of PKR. The serine 18 mutated PACT/Rax can still associate with PKR, but it loses its kinase activity (46). Upon dsRNA or PACT/Rax binding, PKR undergoes a conformational change, which results in dimerization and autophosphorylation at Thr-446 and Thr-451 (47-51). Once activated, PKR phosphorylates its substrates down stream; the $\alpha$-subunit of eukaryotic translation initiation factor-2 (eIF2 $\alpha)$ is the main substrate of PKR $(52 ; 53)$. While PKR can be positively regulated by ds-RNA and PACT/Rax, it can also be 
negatively regulated by its cellular inhibitor, P58, a member of the tetratricopeptide (TPR) family of proteins (54). P58 is activated upon influenza virus infection (55). It is capable of inhibiting PKR activation and eIF2 $\alpha$ phosphorylation by direct interaction with PKR, blocking PKR dimerization (56).

The eukaryotic translation initiation factor-2 (eIF2) is required in the first step of initiation in protein synthesis. It is composed of $\alpha$-, $\beta$ - and $\gamma$-subunits $(57 ; 58)$. The function of eIF $2 \alpha$ is to mediate the binding of the initiator tRNA and Met-tRNAi, to the 40S-ribosomal subunit as a complex in a GTP-dependent manner (59). When PKR phosphorylates eIF $2 \alpha$ at serine-51, it converts eIF2 from a substrate to an inhibitor of its guanine nucleotide exchange factor, eIF2B (60). This reduction in recycling of eIF2 by eIF2B leads to inhibition of translation initiation (61). Phosphorylation of the $\alpha$-subunit in eIF2 occurs in cells or in cell-free translational systems in response to various stimuli, including ethanol (62). The present study is designed to explore the mechanism(s) of ethanol-induced protein synthesis inhibition in neural systems in vitro and in vivo. Our results show that ethanol activates eIF $2 \alpha$ and leads to protein synthesis inhibition, at least in part, via PACT/Rax-PKR-eIF2 $\alpha$ signal transducting pathway. 


\section{Materials and Methods}

\section{Inhibitors}

Two kinds of PKR inhibitors were used, 2-Aminopurine (2-Ap) was purchased from Sigma (St. Louis, MO) and PKR inhibitor was purchased from EMD Biosciences (Darmstadt, Germany).

\section{Animal surgeries and tissue collection}

For non-ethanol treatment: Sprague-Dawley rats were obtained from HarlanSprague-Dawley (Indianapolis, IN, USA). The animals were maintained in a temperature / humidity controlled facility with a 12-h light / dark cycle. All animal protocols were approved by the ACUC of West Virginia University and complied with the NIH guidelines for animal care and use. The number of animals represented a minimal but adequate number for statistical analysis. Cerebellar tissues were collected from pups on the designed postnatal days. Pups were anesthetized by injection of ketamine / xylazine and decapitated. Their cerebella were harvested by cutting through the cerebellar peduncles, frozen on dry ice, and stored at $-80^{\circ} \mathrm{C}$ for further processing.

For ethanol treatment: Long-Evans male and female breeders obtained from Simonsen Laboratory (Gilory, CA) and housed in the PUI vivarium, were placed together on designated evenings and allowed to mate overnight. Gestational day (GD) 0 was defined as the first morning that sperm was detected on a vaginal smear after overnight mating. GD 22 was designated as PD 0 , and more than $80 \%$ of births occurred on GD 22. Rats born on GD 21 were considered PD 0 the following day and rats born on GD 23 were considered PD 1 on that day. Pups were identified by a code, using a permanent tattoo on one or more paw, produced by subcutaneous injection of a small amount of 
nontoxic black ink (performed prior to group assignment). Fourteen pups were assigned to two groups. There were two kinds of treatment in each group, intubated with milk formula (control treatment) or a solution of $11.33 \%(\mathrm{v} / \mathrm{v})$ ethanol in milk formula (ethanol treatment) in a volume of $0.03 \mathrm{ml} / \mathrm{g}$ body weight 3 times a day separated by 2 hours. In group-1, eight pups were assigned to ethanol or control treatment ( 2 males and 2 females each) on postnatal day 9 (PD9). In group-2, six pups were assigned to ethanol or control treatment (1 male and 2 females each) from PD4-9. After treatment, using the protocol described, previously collected cerebellum tissues were frozen on dry ice, and stored at $-80^{\circ} \mathrm{C}$ for further processing.

\section{Cell lines and plasmids}

\section{Cell lines:}

SH-SY5Y, SK-N-MC neuroblastoma and 293 human kidney cell lines were obtained from ATCC and grown in EMEM (DMEM for 293) containing 10.0\% fetal bovine serum (FBS), $2.0 \mathrm{mM} \mathrm{L-glutamine} \mathrm{and} \mathrm{streptomycin}(100 \mu \mathrm{g} / \mathrm{ml}) /$ penicillin $(100$ units $/ \mathrm{ml}$ ) at $37^{\circ} \mathrm{C}$ with $5.0 \% \mathrm{CO}_{2}$.

PKR+/+ and PKR-/- mouse embryonic fibroblasts (MEFs) were obtained from Dennis Baltzis at Lady Davis Institute for Medical Research, McGill University, Quebec, Canada and maintained in Dulbecco's modified Eagle's medium supplemented with 10\% heat-inactivated fetal bovine serum and penicillin-streptomycin $(100 \mathrm{units} / \mathrm{ml})$ at $37^{\circ} \mathrm{C}$ with $5.0 \% \mathrm{CO}_{2}$.

Rax wild type and mutant plasmid:

HA-tagged Rax constructs with wildtype or S18A mutation (substitute Serine to Alanine at site 18) were cloned into vector pcDEF3 which utilizes the EF-1 $\alpha$ promoter. 
Lipofectamine (Invitrogen) was used to transfect plasmids to SK-N-MC or 293 cells according to manufacturer's protocol. Stable clones were selected in G418 $(0.6 \mathrm{mg} / \mathrm{ml})$ and screened by Western blotting with anti-HA antibody.

Primary culture of cerebellar granule cells:

Cultures of cerebellar granule cells (CGCs) were created using a previously described method (63). Briefly, cerebella were obtained from 7-day-old rat pups, and minced with a sterile razor blade and suspended in $10.0 \mathrm{ml}$ of trypsin solution $(0.025 \%)$ at $37^{\circ} \mathrm{C}$. After incubation for $15 \mathrm{~min}$, an equal volume of solution containing DNAse (130 Knuitz units $/ \mathrm{ml})$ and trypsin inhibitor $(0.75 \mathrm{mg} / \mathrm{ml})$ was added and the tissue was sedimented by a brief ( 5 seconds) centrifugation. The tissue was dissociated by trituration, and the cell suspension was centrifuged through a $4.0 \%$ bovine serum albumin solution, which is a critical step for increasing neuronal viability. The cell pellet was resuspended in Eagle's MEM containing the following supplements: 10.0\% FBS, $25.0 \mathrm{mM}$ $\mathrm{KCl}, 1.0 \mathrm{mM}$ glutamine, $33.0 \mathrm{mM}$ glucose, and penicillin (100.0 units $/ \mathrm{ml}) / \mathrm{streptomycin}$ $(100.0 \mu \mathrm{g} / \mathrm{ml})$. Cells (seeding density of $\left.3.2-6.4 \times 10^{4} / \mathrm{cm}^{2}\right)$ were plated into poly-Dlysine (PDL, $50.0 \mu \mathrm{g} / \mathrm{ml}$ )-coated culture wells or dishes and incubated at $37^{\circ} \mathrm{C}$ in a humidified environment containing $5.0 \% \mathrm{CO}_{2}$ for at least 24 hours before initiating ethanol treatment. Due to ethanol's volatility, a method utilizing sealed containers was used to maintain ethanol levels in the cultured medium (64). With this method, ethanol concentration in the medium can be accurately maintained.

\section{Immunoblots analysis}

The immunoblotting procedure for detecting phosphorylation and expression of signal proteins was performed as previously described (65). For cerebellar tissues, the 
cerebella were homogenized in RIPA buffer $[1.0 \%$ NP40, $0.5 \%$ sodium deoxycholate and $0.1 \%$ SDS in $0.01 \mathrm{M}$ Phosphate-buffered saline (PBS)] and centrifuged at $10,000 \times \mathrm{g}$. The supernatant was collected. For the cultured cells, cells were washed with PBS and lysed with RIPA buffer for 10 minutes, solubilized cells were centrifuged, the supernatant was collected. Protein concentration was determined using Bio-Rad Kit. After that aliquots of equal amounts of the protein were loaded into the lanes of a sodium dodecylsulfate (SDS) $10.0 \%$ polyacrylamide gel. The proteins were separated by electrophoresis, and the separated proteins were transferred to nitrocellulose membranes. The membranes were then blocked with either $5.0 \%$ nonfat dry milk or $5.0 \%$ BSA (for detection of phosphorylation) in $10 \mathrm{mM}$ phosphate-buffered saline (pH 7.4) and $0.05 \%$ Tween-20 (TPBS) at room temperature for one hour to block non-specific immunoreactivity. Subsequently, the membranes were incubated with primary antibodies directed against signaling proteins for $1-2$ hours at room temperature or overnight at $4^{\circ} \mathrm{C}$. After three quick washes in TPBS, the membranes were incubated for 1 hour with a secondary antibody conjugated to horseradish peroxidase (Amersham, Arlington Hts. IL) diluted at 1:2000 in TPBS. The membranes were washed again with TPBS and the immune complexes were detected by the enhanced chemiluminescence method (Amersham). In some cases, the blots were stripped and re-probed with an anti-actin antibody. All of the antibodies except anti-p-eIF2 $\alpha$ and anti-p-PKR (Thr451) were obtained from Santa Cruz Biotechnology (Santa Cruz, CA). The anti-p-eIF2 $\alpha$ was purchased from Biosource International (Camarillo, CA), and the anti-p-PKR (Thr451) was obtained from Cell Signaling technology (Beverly, MA).

\section{Immunoprecipitation}


Immunoprecipitation analysis of protein-protein interaction was performed with a previously described procedure (66). Briefly, an aliquot of cell lysate containing $200 \mu \mathrm{g}$ of protein was incubated with the IP antibody $(1: 50)$ overnight at $4^{\circ} \mathrm{C}$. Twenty microliters of protein $\mathrm{A} / \mathrm{G}$ conjugated to agarose (Santa Cruz Biotech) were added to the lysate, and the mixture was incubated $3 \mathrm{~h}$ at $4^{\circ} \mathrm{C}$. Immunoprecipitates were collected by centrifugation at $10,000 \times \mathrm{g}$ for $10 \mathrm{~min}$. The pellet was washed three times with $0.5 \mathrm{ml}$ RIPA buffer [150 mM NaCL, $50 \mathrm{mM}$ Tris (PH 8.0), 1.0\% Nonidet P-40, 0.10\% SDS, $0.50 \%$ deoxycholic acid sodium, $0.10 \% \mathrm{mg} / \mathrm{ml}$ phenylmethylsulfony fluotide, $1.0 \mathrm{mM}$ sodium orthovanadate, and 3.0\% Aprotinin (Sigma)]. Then pellets were resuspended in $20 \mu 13 \times$ SDS sample buffer and analyzed using the procedures described in the immunoblt analysis.

\section{Protein synthesis assay}

Protein synthesis was measured by incorporation of ${ }^{14} \mathrm{C}$ labeled amino acids (Amersham CFB104). Briefly, cells were seeded in 24-well cell culture trays at the

density of $5 \times 10^{5}$ cells/well. After ethanol treatment for the indicated time, $2.5 \mu \mathrm{Ci}{ }^{14} \mathrm{C}$ amino acid mix was added to the wells, incubated at $37^{\circ} \mathrm{C}$ for 15 minutes and then the medium was removed; the cells were lysed with 1 vol. cold RIPA buffer. Reactions were stopped by the addition of 1 vol. cold $20 \%$ TCA. The acid insoluble fraction was collected on Whatman glass fiber filters $(47 \mathrm{mM} \mathrm{GF} / \mathrm{A})$ and radioactivity was measured by liquid scintillation counting.

\section{Statistical Analysis:}

Differences among treatment groups were tested using analysis of variance (ANOVA). Differences in which $p$ was less than 0.05 were considered statistically 
significant. In cases where significant differences were detected, specific post-hoc comparisons between treatment groups were examined with Student-Newman-Keuls test. 


\section{Results}

\section{Ethanol induces phosphorylation of PKR and eIF2 $\alpha$ in SH-SY5Y, SK-N-MC and primary cultured rat cerebellar granule cells}

Protein synthesis is crucial for maintaining the normal function of the cell. Reduced organ protein content will decrease the abundance of some critical cellular components, such as enzymes, and lead to cellular disfunction or cell death. The cellular protein content is the result of the dynamic balance between rates of protein synthesis and degradation. Previous studies in some non-neuron cells have already shown that ethanol exposure can diminish the rate of protein synthesis by upregulating phosphorylation of eIF $2 \alpha(67-72)$. However the upstream kinases that lead to eIF $2 \alpha$ phosphorylation have not been determined. In this study, we first tried to determine if eIF2 $\alpha$ was involved in ethanol-induced protein synthesis inhibition in neural cells; if it is, then what are the upstream signaling proteins that lead to eIF2 $\alpha$ activation? We treated SH-SY5Y, SK-N$\mathrm{MC}$ and primary cultured rat cerebellar granule cells with $0.4 \%$ ethanol for different time points and found that phosphorylation of eIF2 $\alpha$ was upregulated after ethanol treatment. Since PKR is the best-known physiological activator of eIF2 $\alpha$, we wondered if PKR was involved in ethanol-induced eIF2 $\alpha$ phosphorylation. We tested the PKR's activity and found that, like eIf2 $\alpha$, PKR was also activated by ethanol treatment (Fig. 3.1).

\section{The expression of phosphorylation of PKR and eIF2 $\alpha$ is developmentally regulated} and both can be induced by ethanol exposure

To further test the activity of PKR and eIF2 $\alpha$ in response to ethanol treatment in vivo, we examined the expression of total and phosphorylated forms of PKR and eIF $2 \alpha$ in 
rat cerebellum. The primary targets of ethanol in the developing central nervous system are proliferating cells (73) and the neurogenesis of cerebellar granule cells. These activities occur during the "brain growth spurt" (the third trimester of pregnancy in human and first two postnatal weeks in the rat), therefore making the brain most vulnerable to ethanol exposure during this period of time (74). We adopted the pups from postnatal day (PD) 3 to 21 . In early developing cerebellum, the expression of phosphorylated PKR and eIF2 $\alpha$ are gradually increased along its development (Fig. 3.2A). Ethanol exposure during this period of time alters the activation of PKR and eIF2 $\alpha$. On PD9 or PD4-9, ethanol intubation upregulated the phosphorylation of PKR and eIF $2 \alpha$ in the pups' cerebellum (Fig. 3.2B, C). This result indicated that both PKR and eIF2 $\alpha$ were activated by ethanol exposure in developing rat cerebellum.

\section{PKR is the activator of eIF $2 \alpha$ upon ethanol treatment.}

To confirm the role of PKR in the effect of ethanol on eIF2 $\alpha$ phosphorylation, two well known PKR inhibitors (75-77), 2-AP and PKR inhibitor, were used to pre-treat SHSY5Y cells $0.5 \mathrm{~h}$ before ethanol exposure. Both PKR inhibitors can reduce eIF2 $\alpha$ phosphorylation at concentrations of $10 \mathrm{mM}$ and $500 \mathrm{nM}$, respectively (Fig. 3.3A, B). This, most likely, indicates that PKR is an upstream activator of eIF2 $\alpha$ in response to ethanol exposure. Then we further tested the effect of ethanol on eIF $2 \alpha$ phosphorylation in PKR overexpression (PKR+/+) and PKR knock-out (PKR-/-) mouse embryonic fibroblasts. Ethanol stimulated eIF2 $\alpha$ phosphorylation in PKR $+/+$, but not in PKR-/- cells (Fig. 3.4). This further suggested the crucial role of PKR in ethanol-induced eIF2 $\alpha$ activation.

\section{PACT/Rax is an upstream activator of PKR/eIF2 $\alpha$ upon ethanol exposure}


Ethanol-induced activation of PKR/eIF2 $\alpha$ apparently does not involve dsRNA. So, we wanted to examine the potential upstream activator of PKR. PACT/Rax is a characterized protein activator of PKR and functions as the physiological mediator of stress-induced PKR activation in the absence of double-stranded RNA. We sought to determine whether Rax is involved in ethanol-induced PKR/eIF2 $\alpha$ activation. We both transiently and stably transfected SK-N-MC cells with wild type and S18A (alanine substitution for serine at position 18) Rax genes. As shown in Fig. 3.5, a positive reaction of wild type Rax transfected SK-N-MC cells and a negative reaction of S18A transfected SK-N-MC cells were detected by immunoblots after ethanol exposure compared to vector control. Since PACT/Rax activates PKR through directly binding to its dsRNA binding domain, an immunoprecipitation assay was performed to investigate their association after ethanol treatment. The association of Rax and PKR is increased dramatically in the widetype transiently and stably transfected cells compared to those vector or mutated Rax transfected cells (S18A mutated Rax can still bind to PKR but it is kinase deficient (78) (Fig. 3.6). To confirm that Rax/PKR/eIF2 $\alpha$ is the signal transducting pathway leading to protein synthesis inhibition upon ethanol exposure, a protein synthesis assay was performed in Rax stably-transfected SK-N-MC cells. The protein synthesis was dramatically inhibited in Rax over-expression cells, moderately inhibited in vector transfected cells and slightly inhibited in Rax mutated cells (Fig. 3.7). This result indicates that the Rax/PKR/eIF2 $\alpha$ signal pathway is the major component that mediates ethanol-induced protein synthesis inhibition. 


\section{Discussion}

Heavy, chronic gestational alcohol consumption in pregnant women is detrimental to the fetus' developing nervous system. This alcohol abuse can cause fundamental central nervous system abnormalities known as Fetal Alcohol Syndrome (FAS) in the infants. One of the hallmarks of FAS is microencephaly that results mainly from the decreased protein content of the cerebellum (79). Previous studies have established that ethanol exposure can decrease protein synthesis in some non-neural organs via inhibiting protein synthesis initiation by regulating the eukaryotic initiation factors (eIFs) in translational level (80-82). In one study, the phosphorylation of eIF2 $\alpha$, a crucial factor that controls protein synthesis initiation, can be increased up to $90 \%$ by ethanol treatment (83). We demonstrate that ethanol exposure can also lead to protein synthesis inhibition in SH-SY5Y, SK-N-MC neuroblastoma cell lines, primary cultured cerebellar granule cells and rat cerebellum via increasing eIF2 $\alpha$ activation. Furthermore, we provide an important insight into the intracellular signaling pathway that regulates ethanol-induced phosphorylation of eIF $2 \alpha$ and protein synthesis inhibition. In both in vitro and in vivo experiments, we showed that ethanol exposure induced activation of PKR and led to phosphorylation of its downstream substrate eIF2 $\alpha$. By using the specific PKR inhibitors, PKR overexpression and knock-out MEFs, we confirmed that PKR was the direct activator of eIF2 $\alpha$ phosphorylation. We also demonstrated that PACT/Rax was the upstream activator of PKR in response to ethanol-induced PKR / eIF2 $\alpha$ activation and protein synthesis inhibition by using wildtype and S18A mutated Rax tranfected SK-NMC cells. 
In general, the concentration of ethanol used in vivo is higher than that used in vitro to produce similar effects. Consequently, the concentrations of ethanol we adopted were $0.4 \%$ (40 $\mu$ g ethanol per ml medium) in vitro and $11.33 \%$ in vivo (113.3 $\mu$ g ethanol per $\mathrm{ml}$ milk formula, roughly equal $0.3 \%$ blood ethanol concentration). This is a relatively high concentration, but it is physiologically relevant to the blood alcohol concentration reported to cause Fetal Alcohol Syndrome (84).

\section{PKR is the direct upstream activator of eIF2 $\alpha$ upon ethanol exposure.}

Eukaryotic initiation factor 2 (eIF2), one of a series of proteins that regulated protein synthesis initiation in eukaryotic cells, is composed of $\alpha, \beta$ and $\gamma$ subunits. Phosphorylation at serine 51 of the $\alpha$-subunit of eIF2 (eIF2 $\alpha$ ) blocks the formation of a ternary initiation complex, which involved eIF2, GTP and Met-tRNA $A_{i}$, and protein synthesis initiation will be inhibited. The effect of ethanol on protein synthesis at the molecular level has been investigated previously. Lang et al (85) found that ethanol did not alter ATP and total RNA content in hepatic cells, but increased the proportion of 40S and $60 \mathrm{~S}$ ribosomal subunits in the nonpolysome-associated fraction by $30 \%$, decreased hepatic eIF2B activity by $36 \%$, and increased eIF $2 \alpha$ phosphorylation up to $90 \%$. They also found similar results in skeletal, muscle and myocardial cells (86;87). Another study (88) demonstrated that protein synthesis inhibition induced by ethanol could be overcome by addition of eIF2 in the reticulocyte cell-free system. However none of these studies have investigated the upstream signal protein(s) leading to eIF2 $\alpha$ phosphorylation and protein synthesis inhibition. So far four eIF $2 \alpha$ kinases have been reported, each of them respond to different stimuli: heme-regulated kinase (HRI) by hemin deprivation (89), double-stranded RNA-induced protein kinase (PKR) by dsRNA, and PACT/Rax (90;91), 
GCN2 kinase from yeast (92), Drosophila and mouse (93;94) by amino acid or serum starvation, and PKR-like ER kinase (PERK) by unfolded proteins in response to ERstress (95). All these kinases can lead to eIF $2 \alpha$ phosphorylation and translation initiation inhibition (96-98). Among these kinases, PKR is the best characterized eIF2 $\alpha$ kinase, and recently it has been established that PKR is a component of signal transduction pathways mediating cell growth and response to different stresses (99). If PKR was the activator of eIF2 $\alpha$ with ethanol treatment, we assumed that PKR should have a synonymous reaction with eIF2 $\alpha$. Our results confirmed this. Since PERK is another potential protein kinase that may lead to eIF2 $\alpha$ phosphorylation, we checked the p-PERK and total PERK in these experiments and no synonymous alteration of p-PERK was detected (data not show). Combined with the results from experiments of PKR inhibitors pre-treatment and PKR gene knock out MEFs, we demonstrated that PKR is the upstream kinase of eIF2 $\alpha$ and is activated by ethanol exposure.

\section{Ethanol and cerebellum early development}

Meanwhile, we investigated the activation of PKR and eIF2 $\alpha$ in rat pup's cerebellum during postnatal day (PD) 3-21, the western blots showed that phosphorylation of both was gradually increased, especially after PD9. A possible explanation is, during this time, cerebellar neurons switched gradually from proliferation to differentiation. Previous studies have demonstrated that PKR and eIF2 $\alpha$ function in controlling cell proliferation and differentiation (100). Gradually increased activation of PKR and eIF2 $\alpha$ may control cells slowing down their proliferation rate, and release more mRNAs from polysomes of overall protein synthesis to facilitate the translation of specific mRNAs that are essential for cellular differentiation processes (101). Our in vivo 
experiments showed that intubating pups with ethanol on PD4 or PD4-9 led to upregulation of PKR and eIF $2 \alpha$ activation. The lasting activation of PKR and eIF2 $\alpha$ may be the reason that leads to the decrease protein content in the developing cerebellum after chronic ethanol exposure.

\section{Intracellular signaling pathway for ethanol action}

Two activators of PKR have been reported: dsRNA and PACT/Rax. Since previous studies have shown that ethanol exposure did not lead to RNA content alteration (102) and PACT/Rax is the known intracellular PKR mediator in response to different stresses independent of ds-RNA $(103 ; 104)$, PACT/Rax is likely the activator of PKR/eIF2 $\alpha$ in response to ethanol treatment. To test this hypothesis, we transfected SK-N-MC cells with wild type and S18A mutated Rax genes both transiently and stably. There are 15 phosphorylatable serines within Rax protein sequence, but only those phosphorylated at serine 18 are able to activate PKR. The non-phosphorylatable Rax, $\operatorname{Rax}(\mathrm{S} 18 \mathrm{~A})$, can still bind with PKR but since it has lost its kinase activity, it fails to induce eIF2 $\alpha$ phosphorylation (105). Our western blots showed that phosphorylation of PKR and eIF2 $\alpha$ were increased significantly in Rax overexpression cells than in Rax mutant cells. Since Rax activates PKR through direct association, immunoprecipitation experiments were performed to investigate the interaction between Rax and PKR. Our results demonstrated that the association between Rax and PKR increased dramatically in wild-type Rax transfected cells compared to control cells (PKR can not be activated in mutant cells, for mutant Rax has no kinase activity though its interaction increased). In addition, we examined the protein synthesis rates in these Rax transfected cells by ${ }^{14} \mathrm{C}$ amino acids incorporation assay and the rate is much slower in Rax wildtype cells than in Rax 
mutated (S18A) cells. The conclusion from these experiments is that PACT/Rax-PKReIF $2 \alpha$ is the signaling pathway leading to protein synthesis inhibition upon ethanol exposure in cerebellar granule cells.

Alcohol exposure has a profound effect on central nervous system development. Our study provides an important insight into a potential mechanism for the effect of ethanol on the development of CNS. 
Figures 
Figure 3.1 A. SH-SY5Y cells treated with ethanol (0.4\%)

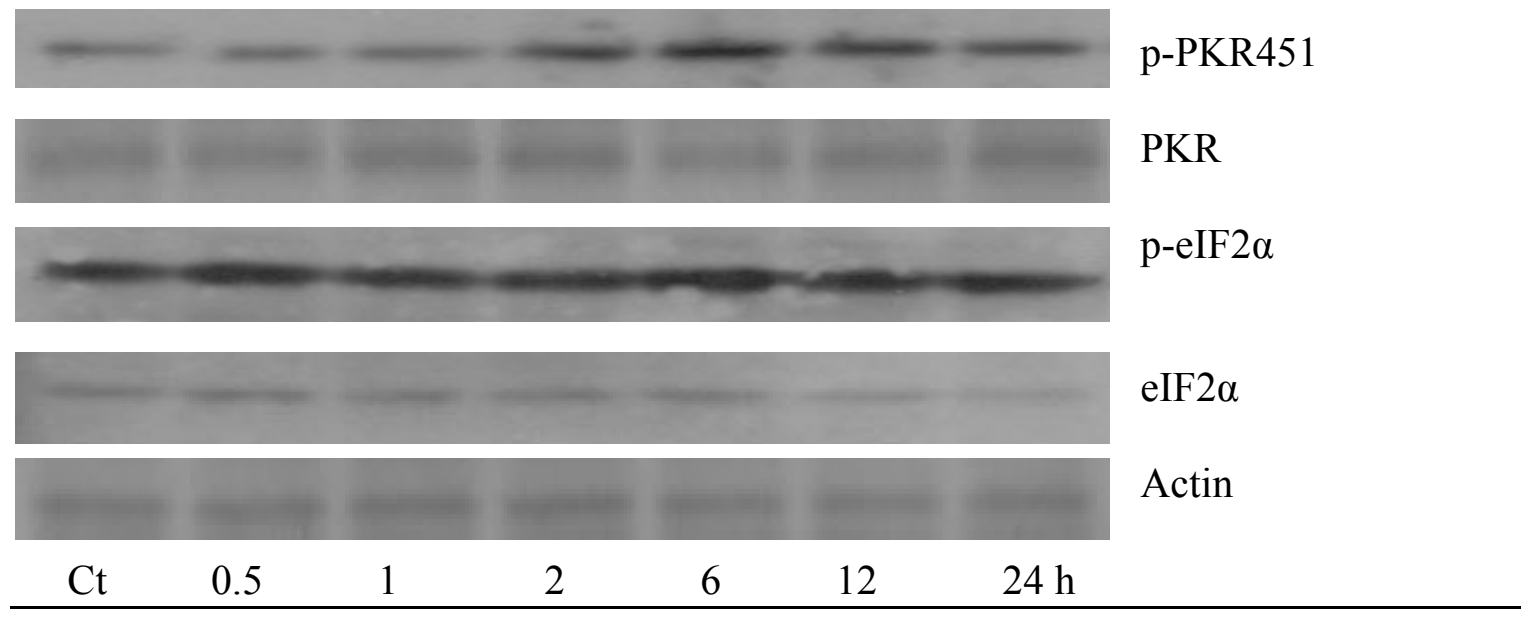

B.293 cells treated with ethanol $(0.4 \%)$

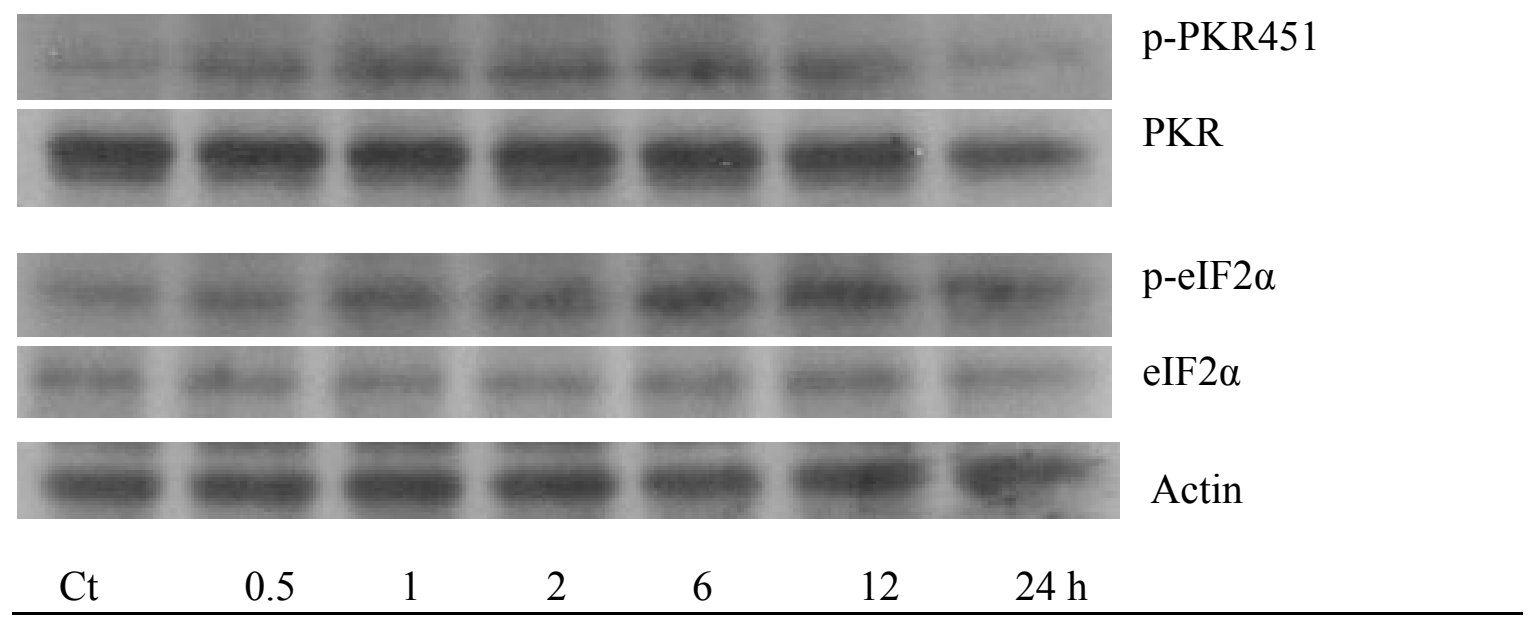

C. Primary cultured cerebellar granule cells treated with ethanol $(0.4 \%)$

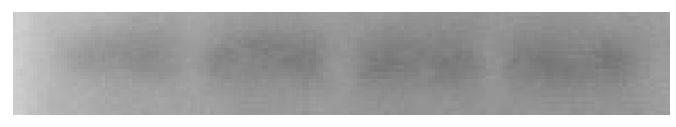

p-PKR451

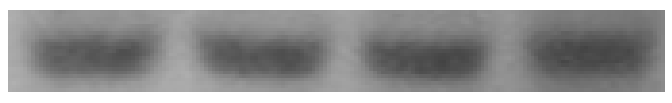

PKR

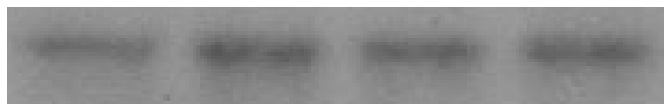

p-eIF $2 \alpha$

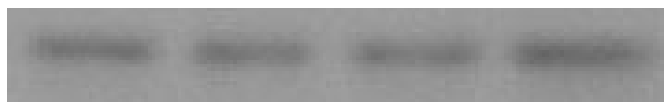

eIF $2 \alpha$

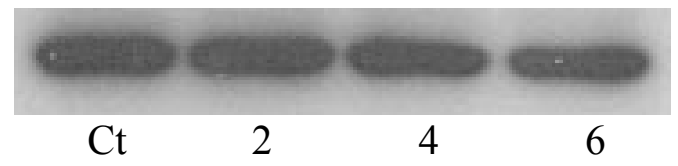

Actin 
Figure 3. 1 Effect of ethanol on PKR and eIF2 $\alpha$ activation

PKR and eIF2 $\alpha$ are activated by ethanol treatment. The expression of phosphorylated PKR and eIF2 $\alpha$, total PKR and eIF2 $\alpha$ were determined by immunoblots in: A. SH-SY5Y cells which were cultured in serum-free medium for $24 \mathrm{~h}$ then exposed to ethanol $(0$ or 0.4\%). B. 293 cells which were cultured in serum-free medium for $24 \mathrm{~h}$ before ethanol (0 or $0.4 \%)$ treatment. C. Ethanol $(0$ or $0.4 \%)$ treated primary cultured cerebellar granule cells. The experiment was replicated three times. 
Fig. 3.2

A. Normal developing cerebellum (PD3-21)

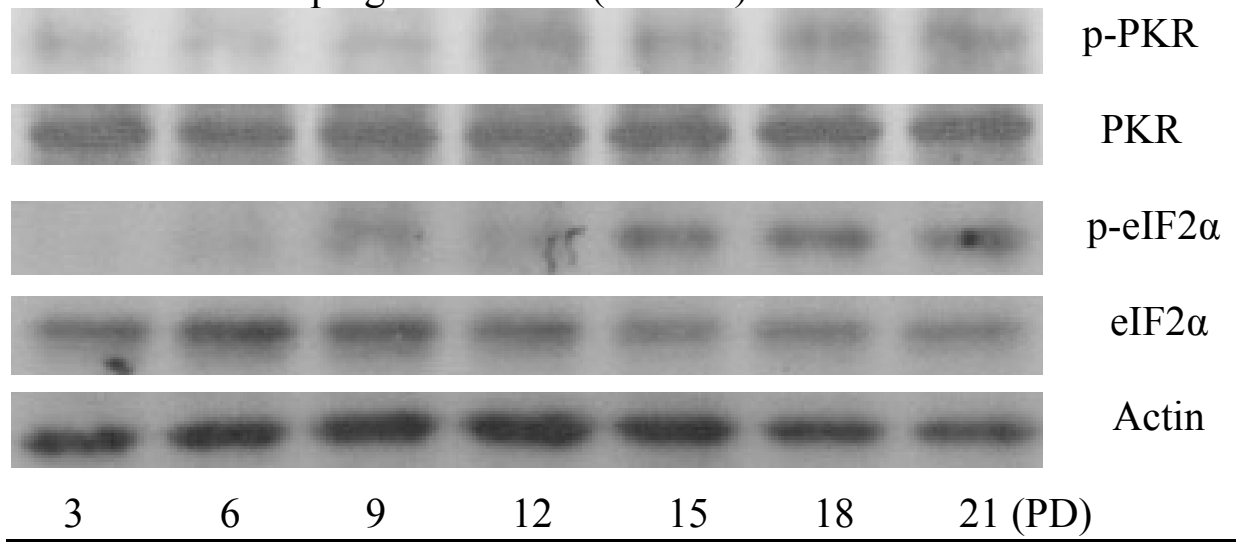

B. Cerebellum (PD4-9 ethanol treatment)

\begin{tabular}{ll} 
p-PKR \\
Rax \\
p-eIF2 $\alpha$ \\
eIF2 $\alpha$ \\
\hline milk & Actin \\
\hline
\end{tabular}

C. Cerebellum (PD9)

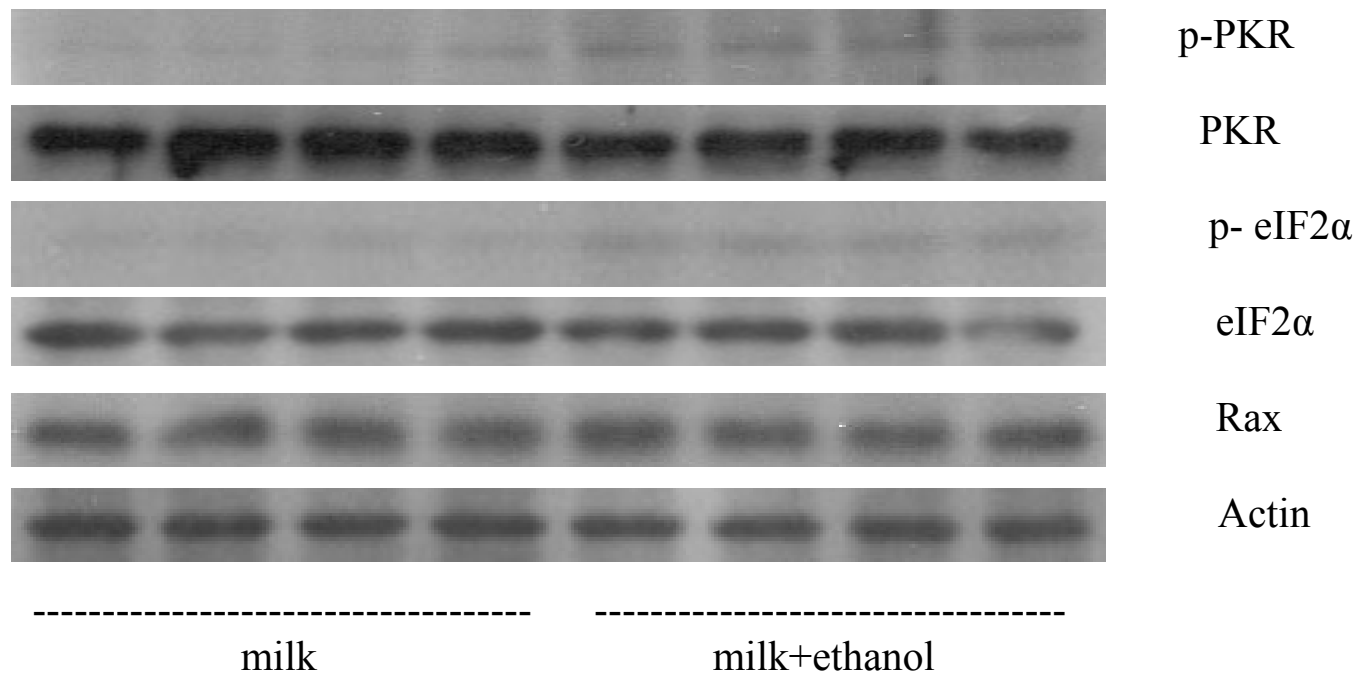


Figure 3. 2 Ethanol upregulates phosphorylation of PKR and eIF2 $\alpha$ in rat pup's cerebellum

(A). The expression of phosphorylation of PKR and eIF2 $\alpha$, total PKR and eIF2 $\alpha$ were determined by immunoblots in PD3-21 rat pup's cerebellum.

(B) and (C). The expression of phosphorylation of PKR and eIF2 $\alpha$ increased in pup's cerebella which were intubated with ethanol (11.33\%) plus milk formula on PD4-9 or PD9 compared to intubated with milk formula only (control).

The experiment was replicated three times. 
Figure 3.3

A. SH-SY5Y cells pre-treated with 2-AP $0.5 \mathrm{~h}$ before ethanol exposure

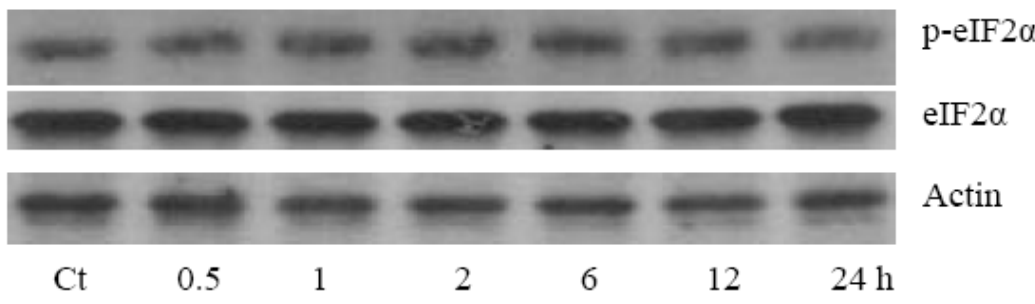

B. SH-SY5Y cells pre-treated with PKR Inhibitor $0.5 \mathrm{~h}$ before ethanol exposure

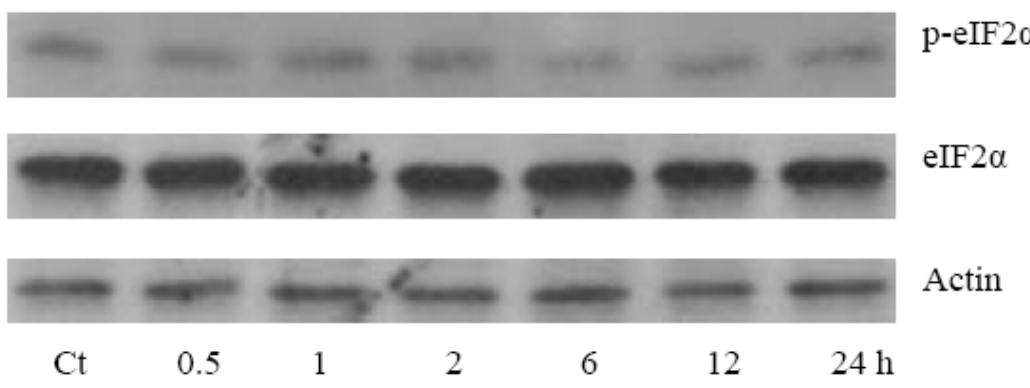

Figure 3. 3 Effect of PKR inhibitors on ethanol-induced eIF2 $\alpha$ phosphorylation

PKR inhibitors block ethanol-induced eIF2 $\alpha$ activation. SH-SY5Y cells were maintained in serum-free medium for $24 \mathrm{~h}$ then pre-treated with 2-AP (10 mM) (A) or PKR inhibitor $(500 \mathrm{nM})(\mathrm{B}) 0.5 \mathrm{~h}$ before ethanol $(0$ or $0.4 \%)$ exposure. The expression of phosphorylation of eIF2 $\alpha$ and total eIF2 $\alpha$ were determined by immunoblots. The experiment was replicated three times. 
Figure 3.4. PKR $+/+$ and PKR-/- MEF treated with ethanol

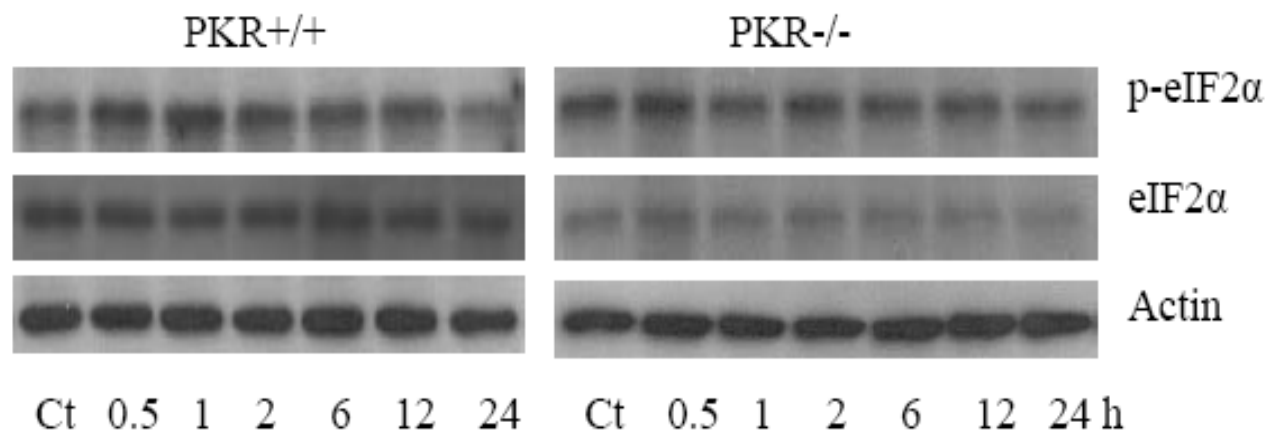

Figure 3. 4 Ethanol fails to induce eIF2 $\alpha$ activation in PKR-deficient MEFs

The PKR+/+ and PKR-/- mouse embryonic fibroblasts were cultured in serum-free medium for $24 \mathrm{~h}$ before ethanol ( 0 or $0.4 \%)$ treatment. The expression of phosphorylation of eIF $2 \alpha$ and total eIF $2 \alpha$ were determined by immunoblots. The experiment was replicated three times. 
Figure 3.5

\section{A}

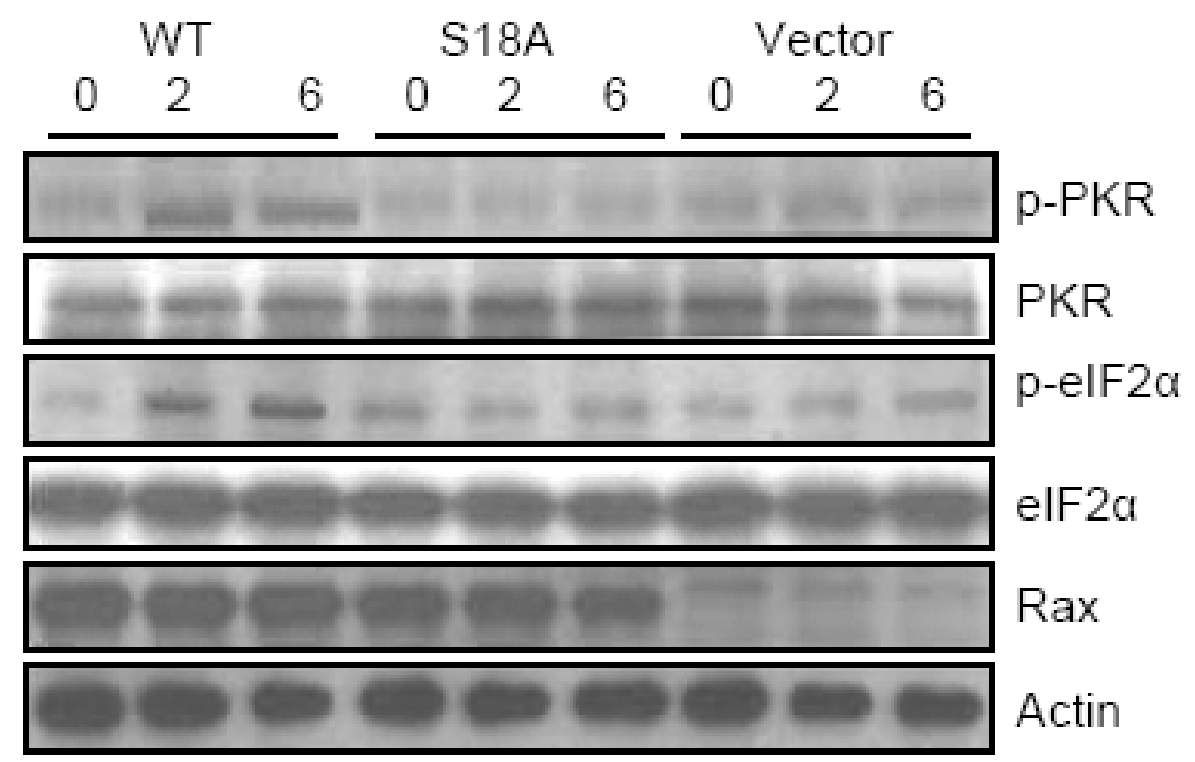

B

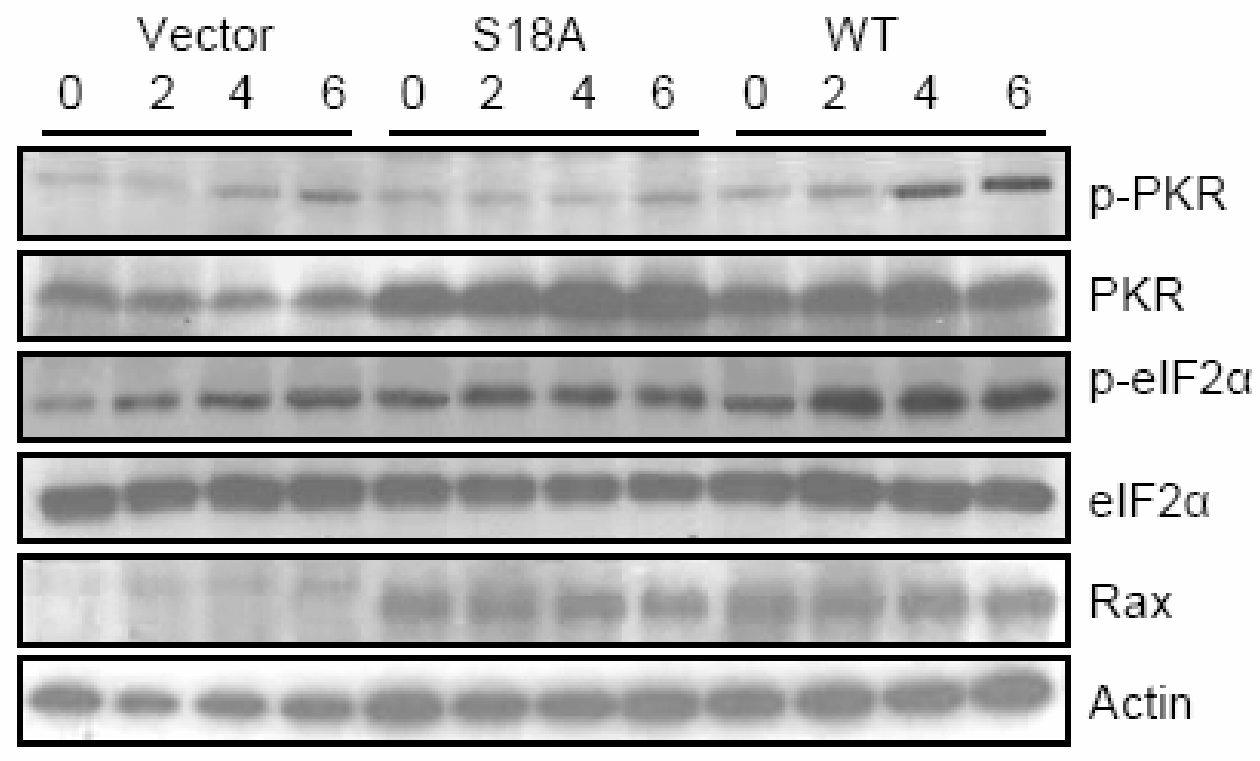


Figure 3.5 Effect of ethanol on eIF2 $\alpha$ phophorylation in wildtype and serine 18 mutated Rax transfected SK-N-MC cells

Wildtype Rax gene transfected SK-N-MC cells are more sensitive to ethanol's action, but not in Rax mutant transfected SK-N-MC cells. (A). SK-N-MC cells transiently transfected with wild type or serine 18 mutated Rax genes were cultured in serum-free medium for $24 \mathrm{~h}$ before treated with ethanol $(0$ or $0.4 \%)$ for 2,4 or 6 hours. The expression of phosphorylation of eIF2 $\alpha$ and PKR, total eIF2 $\alpha$ and PKR were determined by immunoblots.

(B). Wild type or serine 18 mutated Rax gene stably transfected SK-N-MC cells were cultured in serum-free medium for $24 \mathrm{~h}$ then exposed to ethanol ( 0 or $0.4 \%)$ for 2,4 or 6 hours. The expression of phosphorylation of eIF $2 \alpha$ and total eIF $2 \alpha$ were determined by immunoblots.

The experiment was replicated three times. 
Figure 3.6

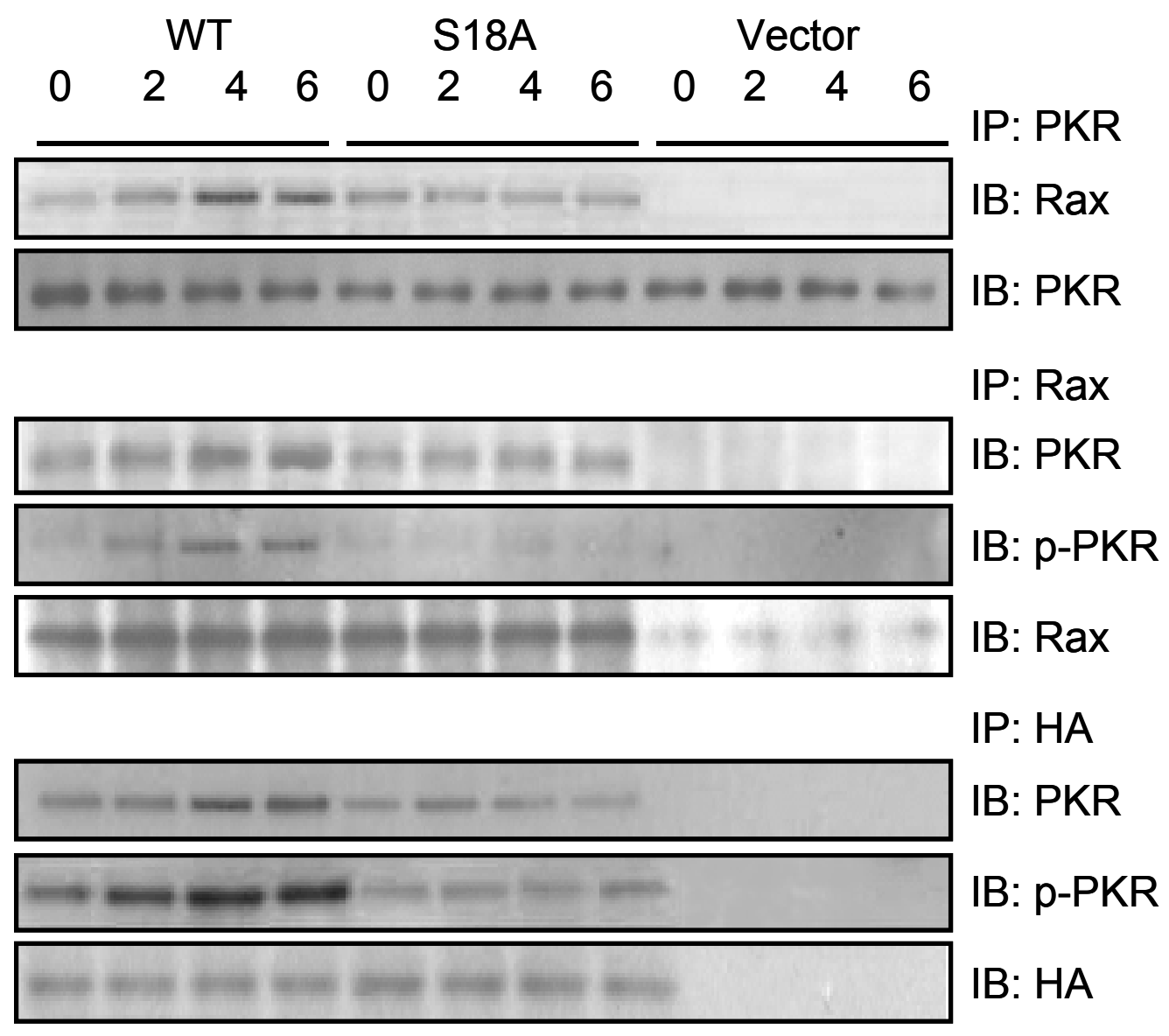

Figure 3. 6 Ethanol promotes the association between PKR and Rax

Wild type or serine 18 mutated Rax genes were stably transfected in SK-N-MC cells and exposed to ethanol ( 0 or $0.4 \%$ ) after 2,4 and 6 hs. The association of PKR and Rax or PKR and HA (tag) was determined by immunoprecipitation using anti-PKR, anti-Rax or anti-HA antibodies. The experiment was replicated three times. 
Figure 3.7

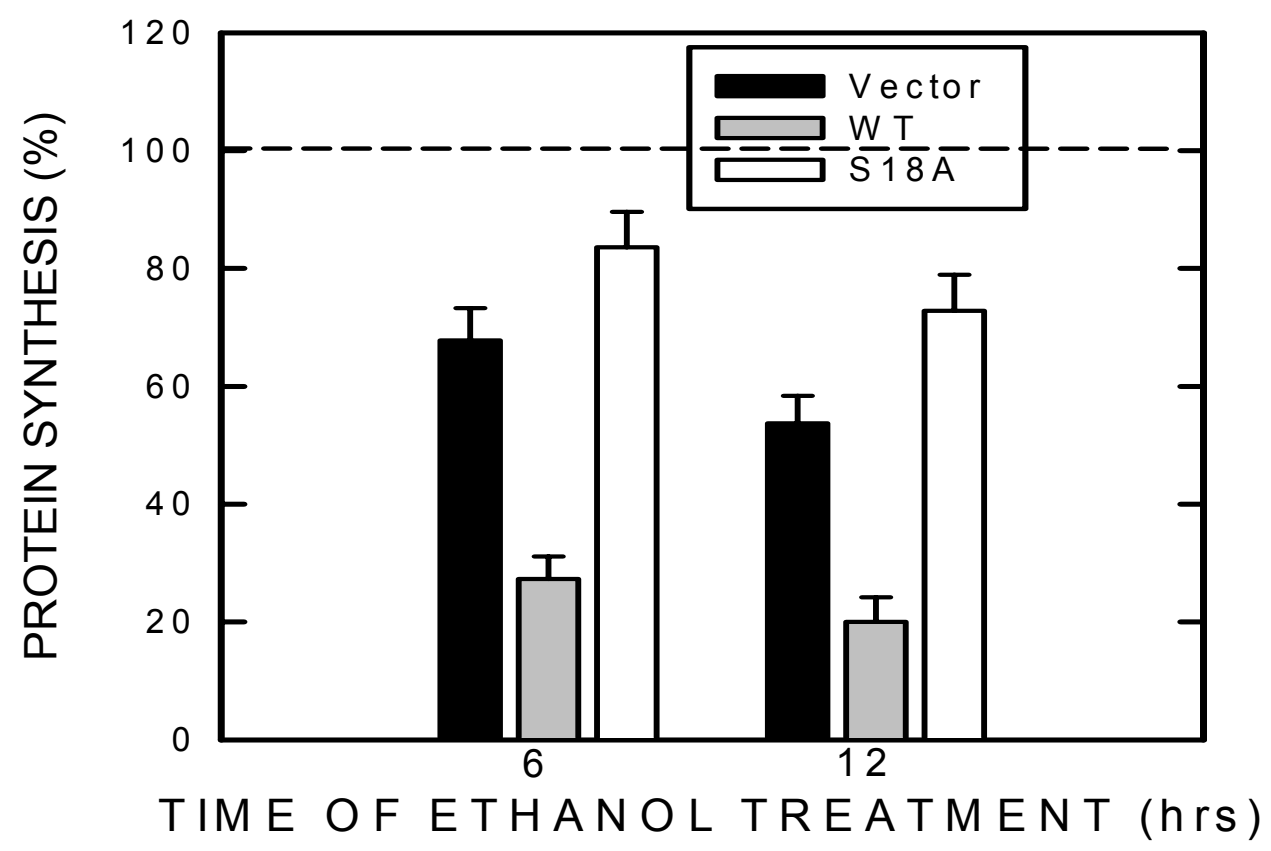

Figure 3. 7 Ethanol-induced protein synthesis inhibition was alleviated in Rax mutated SK-N-MC cells

Protein synthesis was measured in wildtype and S18A mutated Rax stable transfected SK-N-MC cells treated with $0.4 \%$ ethanol by the incorporation ${ }^{14} \mathrm{C}$ labeled amino acids. The differences among all groups were statistically significant $(\mathrm{p}<0.05)$. 


\section{Reference List}

1. Bonthius, D. J., West, J. R. (1990) Alcohol-induced neuronal loss in developing rats: increased brain damage with binge exposure. Alcohol Clin.Exp.Res. 14, $107-$ 118

2. West, J. R. (1993) Acute and long-term changes in the cerebellum following developmental exposure to ethanol. Alcohol Alcohol Suppl 2, 199-202

3. Streissguth, A. P., Landesman-Dwyer, S., Martin, J. C., Smith, D. W. (1980) Teratogenic effects of alcohol in humans and laboratory animals. Science 209, 353-361

4. Diamond, I., Gordon, A. S. (1997) Cellular and molecular neuroscience of alcoholism. Physiol Rev. 77, 1-20

5. Marcussen, B. L., Goodlett, C. R., Mahoney, J. C., West, J. R. (1994) Developing rat Purkinje cells are more vulnerable to alcohol-induced depletion during differentiation than during neurogenesis. Alcohol 11, 147-156

6. Streissguth, A. P., O'Malley, K. (2000) Neuropsychiatric implications and longterm consequences of fetal alcohol spectrum disorders.

Semin.Clin.Neuropsychiatry 5, 177-190

7. Diaz, J., Samson, H. H. (1980) Impaired brain growth in neonatal rats exposed to ethanol. Science 208, 751-753

8. Salman, M. S. (2002) The cerebellum: it's about time! But timing is not everything--new insights into the role of the cerebellum in timing motor and cognitive tasks. J.Child Neurol. 17, 1-9

9. Marien, P., Engelborghs, S., Fabbro, F., De Deyn, P. P. (2001) The lateralized linguistic cerebellum: a review and a new hypothesis. Brain Lang 79, 580-600

10. Jones, K. L., Smith, D. W. (1973) Recognition of the fetal alcohol syndrome in early infancy. Lancet 2, 999-1001

11. Eckardt, M. J., File, S. E., Gessa, G. L., Grant, K. A., Guerri, C., Hoffman, P. L., Kalant, H., Koob, G. F., Li, T. K., Tabakoff, B. (1998) Effects of moderate alcohol consumption on the central nervous system. Alcohol Clin.Exp.Res. 22, 998-1040

12. Marcus, J. C. (1987) Neurological findings in the fetal alcohol syndrome. Neuropediatrics 18, 158-160

13. Eckardt, M. J., File, S. E., Gessa, G. L., Grant, K. A., Guerri, C., Hoffman, P. L., Kalant, H., Koob, G. F., Li, T. K., Tabakoff, B. (1998) Effects of moderate 
alcohol consumption on the central nervous system. Alcohol Clin.Exp.Res. 22, 998-1040

14. Guerri, C. (1998) Neuroanatomical and neurophysiological mechanisms involved in central nervous system dysfunctions induced by prenatal alcohol exposure. Alcohol Clin.Exp.Res. 22, 304-312

15. Bauer-Moffett, C., Altman, J. (1977) The effect of ethanol chronically administered to preweanling rats on cerebellar development: a morphological study. Brain Res. 119, 249-268

16. Nathaniel, E. J., Nathaniel, D. R., Mohamed, S., Nathaniel, L., Kowalzik, C., Nahnybida, L. (1986) Prenatal ethanol exposure and cerebellar development in rats. Exp.Neurol. 93, 601-609

17. Miller, M. W. (1996) Effect of early exposure to ethanol on the protein and DNA contents of specific brain regions in the rat. Brain Res. 734, 286-294

18. Vary, T. C., Nairn, A. C., Lang, C. H. (2004) Restoration of protein synthesis in heart and skeletal muscle after withdrawal of alcohol. Alcohol Clin.Exp.Res. 28, $517-525$

19. Lang, C. H., Frost, R. A., Kumar, V., Vary, T. C. (2000) Impaired myocardial protein synthesis induced by acute alcohol intoxication is associated with changes in eIF4F. Am.J.Physiol Endocrinol.Metab 279, E1029-E1038

20. Lang, C. H., Wu, D., Frost, R. A., Jefferson, L. S., Vary, T. C., Kimball, S. R. (1999) Chronic alcohol feeding impairs hepatic translation initiation by modulating eIF2 and eIF4E. Am.J.Physiol 277, E805-E814

21. Lang, C. H., Wu, D., Frost, R. A., Jefferson, L. S., Kimball, S. R., Vary, T. C. (1999) Inhibition of muscle protein synthesis by alcohol is associated with modulation of eIF2B and eIF4E. Am.J.Physiol 277, E268-E276

22. Wu, J. M. (1981) Control of protein synthesis in rabbit reticulocytes. Inhibition of polypeptide synthesis by ethanol. J.Biol.Chem. 256, 4164-4167

23. Lang, C. H., Wu, D., Frost, R. A., Jefferson, L. S., Kimball, S. R., Vary, T. C. (1999) Inhibition of muscle protein synthesis by alcohol is associated with modulation of eIF2B and eIF4E. Am.J.Physiol 277, E268-E276

24. Lang, C. H., Wu, D., Frost, R. A., Jefferson, L. S., Vary, T. C., Kimball, S. R. (1999) Chronic alcohol feeding impairs hepatic translation initiation by modulating eIF2 and eIF4E. Am.J.Physiol 277, E805-E814

25. Kaufman, R. J. (1999) Double-stranded RNA-activated protein kinase mediates virus-induced apoptosis: a new role for an old actor. Proc.Natl.Acad.Sci.U.S.A 96, 11693-11695 
26. Levin, D., London, I. M. (1978) Regulation of protein synthesis: activation by double-stranded RNA of a protein kinase that phosphorylates eukaryotic initiation factor 2. Proc.Natl.Acad.Sci.U.S.A 75, 1121-1125

27. Wu, S., Kaufman, R. J. (1996) Double-stranded (ds) RNA binding and not dimerization correlates with the activation of the dsRNA-dependent protein kinase (PKR). J.Biol.Chem. 271, 1756-1763

28. Wu, S., Kaufman, R. J. (1997) A model for the double-stranded RNA (dsRNA)dependent dimerization and activation of the dsRNA-activated protein kinase PKR. J.Biol.Chem. 272, 1291-1296

29. Tan, S. L., Katze, M. G. (1999) The emerging role of the interferon-induced PKR protein kinase as an apoptotic effector: a new face of death? J.Interferon Cytokine Res. 19, 543-554

30. Gunnery, S., Mathews, M. B. (1998) RNA binding and modulation of PKR activity. Methods 15, 189-198

31. Gale, M., Jr., Blakely, C. M., Kwieciszewski, B., Tan, S. L., Dossett, M., Tang, N. M., Korth, M. J., Polyak, S. J., Gretch, D. R., Katze, M. G. (1998) Control of PKR protein kinase by hepatitis $C$ virus nonstructural 5A protein: molecular mechanisms of kinase regulation. Mol.Cell Biol. 18, 5208-5218

32. Tian, B., Mathews, M. B. (2001) Functional characterization of and cooperation between the double-stranded RNA-binding motifs of the protein kinase PKR. J.Biol.Chem. 276, 9936-9944

33. Ung, T. L., Cao, C., Lu, J., Ozato, K., Dever, T. E. (2001) Heterologous dimerization domains functionally substitute for the double-stranded RNA binding domains of the kinase PKR. EMBO J. 20, 3728-3737

34. Tan, S. L., Katze, M. G. (1999) The emerging role of the interferon-induced PKR protein kinase as an apoptotic effector: a new face of death? J.Interferon Cytokine Res. 19, 543-554

35. Proud, C. G. (1995) PKR: a new name and new roles. Trends Biochem.Sci. 20, $241-246$

36. Williams, B. R. (1997) Role of the double-stranded RNA-activated protein kinase (PKR) in cell regulation. Biochem.Soc.Trans. 25, 509-513

37. Gil, J., Esteban, M. (2000) Induction of apoptosis by the dsRNA-dependent protein kinase (PKR): mechanism of action. Apoptosis. 5, 107-114

38. Patel, C. V., Handy, I., Goldsmith, T., Patel, R. C. (2000) PACT, a stressmodulated cellular activator of interferon-induced double-stranded RNA-activated protein kinase, PKR. J.Biol.Chem. 275, 37993-37998 
39. Williams, B. R. (1999) PKR; a sentinel kinase for cellular stress. Oncogene 18, $6112-6120$

40. Williams, B. R. (2001) Signal integration via PKR. Sci.STKE. 2001, RE2

41. D'Acquisto, F., Ghosh, S. (2001) PACT and PKR: turning on NF-kappa B in the absence of virus. Sci.STKE. 2001, RE1

42. Rowe, T. M., Sen, G. C. (2001) Organizations and promoter analyses of the human and the mouse genes for PACT, the protein-activator of the interferoninduced protein kinase, PKR. Gene 273, 215-225

43. Patel, R. C., Sen, G. C. (1998) PACT, a protein activator of the interferon-induced protein kinase, PKR. EMBO J. 17, 4379-4390

44. Ito, T., Yang, M., May, W. S. (1999) RAX, a cellular activator for doublestranded RNA-dependent protein kinase during stress signaling. J.Biol.Chem. $274,15427-15432$

45. Patel, R. C., Sen, G. C. (1998) PACT, a protein activator of the interferon-induced protein kinase, PKR. EMBO J. 17, 4379-4390

46. Bennett, R. L., Blalock, W. L., May, W. S. (2004) Serine 18 phosphorylation of RAX, the PKR activator, is required for PKR activation and consequent translation inhibition. J.Biol.Chem. 279, 42687-42693

47. Wu, S., Kaufman, R. J. (1996) Double-stranded (ds) RNA binding and not dimerization correlates with the activation of the dsRNA-dependent protein kinase (PKR). J.Biol.Chem. 271, 1756-1763

48. Wu, S., Kaufman, R. J. (1997) A model for the double-stranded RNA (dsRNA)dependent dimerization and activation of the dsRNA-activated protein kinase PKR. J.Biol.Chem. 272, 1291-1296

49. Tan, S. L., Katze, M. G. (1999) The emerging role of the interferon-induced PKR protein kinase as an apoptotic effector: a new face of death? J.Interferon Cytokine Res. 19, 543-554

50. Gunnery, S., Mathews, M. B. (1998) RNA binding and modulation of PKR activity. Methods 15, 189-198

51. Romano, P. R., Zhang, F., Tan, S. L., Garcia-Barrio, M. T., Katze, M. G., Dever, T. E., Hinnebusch, A. G. (1998) Inhibition of double-stranded RNA-dependent protein kinase PKR by vaccinia virus E3: role of complex formation and the E3 N-terminal domain. Mol.Cell Biol. 18, 7304-7316

52. Williams, B. R. (1999) PKR; a sentinel kinase for cellular stress. Oncogene 18, $6112-6120$ 
53. Clemens, M. J. (1997) PKR--a protein kinase regulated by double-stranded RNA. Int.J.Biochem.Cell Biol. 29, 945-949

54. Polyak, S. J., Tang, N., Wambach, M., Barber, G. N., Katze, M. G. (1996) The P58 cellular inhibitor complexes with the interferon-induced, double-stranded RNA-dependent protein kinase, PKR, to regulate its autophosphorylation and activity. J.Biol.Chem. 271, 1702-1707

55. Lee, T. G., Tang, N., Thompson, S., Miller, J., Katze, M. G. (1994) The 58,000dalton cellular inhibitor of the interferon-induced double-stranded RNA-activated protein kinase $(\mathrm{PKR})$ is a member of the tetratricopeptide repeat family of proteins. Mol.Cell Biol. 14, 2331-2342

56. Tan, S. L., Gale, M. J., Jr., Katze, M. G. (1998) Double-stranded RNAindependent dimerization of interferon-induced protein kinase PKR and inhibition of dimerization by the cellular P58IPK inhibitor. Mol.Cell Biol. 18, 2431-2443

57. Antoun, A., Pavlov, M. Y., Andersson, K., Tenson, T., Ehrenberg, M. (2003) The roles of initiation factor 2 and guanosine triphosphate in initiation of protein synthesis. EMBO J. 22, 5593-5601

58. Fernandez, J., Yaman, I., Sarnow, P., Snider, M. D., Hatzoglou, M. (2002)

Regulation of internal ribosomal entry site-mediated translation by phosphorylation of the translation initiation factor eIF2alpha. J.Biol.Chem. 277, 19198-19205

59. Antoun, A., Pavlov, M. Y., Andersson, K., Tenson, T., Ehrenberg, M. (2003) The roles of initiation factor 2 and guanosine triphosphate in initiation of protein synthesis. EMBO J. 22, 5593-5601

60. Sudhakar, A., Ramachandran, A., Ghosh, S., Hasnain, S. E., Kaufman, R. J., Ramaiah, K. V. (2000) Phosphorylation of serine 51 in initiation factor 2 alpha (eIF2 alpha) promotes complex formation between eIF2 alpha(P) and eIF2B and causes inhibition in the guanine nucleotide exchange activity of eIF2B.

Biochemistry 39, 12929-12938

61. Talloczy, Z., Jiang, W., Virgin, H. W., Leib, D. A., Scheuner, D., Kaufman, R. J., Eskelinen, E. L., Levine, B. (2002) Regulation of starvation- and virus-induced autophagy by the eIF2alpha kinase signaling pathway. Proc.Natl.Acad.Sci.U.S.A 99, 190-195

62. Cox, S., Proud, C. G. (1988) The effect of ethanol on polypeptide chain initiation in reticulocyte lysates. Inhibition of recycling of initiation factor eIF-2.

Biochem.Pharmacol. 37, 2045-2049

63. Chen, G., Bower, K. A., Ma, C., Fang, S., Thiele, C. J., Luo, J. (2004) Glycogen synthase kinase 3 beta (GSK3beta) mediates 6-hydroxydopamine-induced neuronal death. FASEB J. 18, 1162-1164 
64. Luo, J., Miller, M. W. (1997) Differential sensitivity of human neuroblastoma cell lines to ethanol: correlations with their proliferative responses to mitogenic growth factors and expression of growth factor receptors. Alcohol Clin.Exp.Res. $21,1186-1194$

65. Chen, G., Bower, K. A., Ma, C., Fang, S., Thiele, C. J., Luo, J. (2004) Glycogen synthase kinase 3 beta (GSK3beta) mediates 6-hydroxydopamine-induced neuronal death. FASEB J. 18, 1162-1164

66. Luo, J., West, J. R., Cook, R. T., Pantazis, N. J. (1999) Ethanol induces cell death and cell cycle delay in cultures of pheochromocytoma PC12 cells. Alcohol Clin.Exp.Res. 23, 644-656

67. Lang, C. H., Wu, D., Frost, R. A., Jefferson, L. S., Vary, T. C., Kimball, S. R. (1999) Chronic alcohol feeding impairs hepatic translation initiation by modulating eIF2 and eIF4E. Am.J.Physiol 277, E805-E814

68. Lang, C. H., Frost, R. A., Kumar, V., Vary, T. C. (2000) Impaired myocardial protein synthesis induced by acute alcohol intoxication is associated with changes in eIF4F. Am.J.Physiol Endocrinol.Metab 279, E1029-E1038

69. Lang, C. H., Kimball, S. R., Frost, R. A., Vary, T. C. (2001) Alcohol myopathy: impairment of protein synthesis and translation initiation. Int.J.Biochem.Cell Biol. $33,457-473$

70. Vary, T. C., Lynch, C. J., Lang, C. H. (2001) Effects of chronic alcohol consumption on regulation of myocardial protein synthesis. Am.J.Physiol Heart Circ.Physiol 281, H1242-H1251

71. Vary, T. C., Nairn, A. C., Lang, C. H. (2004) Restoration of protein synthesis in heart and skeletal muscle after withdrawal of alcohol. Alcohol Clin.Exp.Res. 28, $517-525$

72. Wu, J. M. (1981) Control of protein synthesis in rabbit reticulocytes. Inhibition of polypeptide synthesis by ethanol. J.Biol.Chem. 256, 4164-4167

73. Luo, J., Miller, M. W. (1998) Growth factor-mediated neural proliferation: target of ethanol toxicity. Brain Res.Brain Res.Rev. 27, 157-167

74. Costa, L. G., Vitalone, A., Guizzetti, M. (2004) Signal transduction mechanisms involved in the antiproliferative effects of ethanol in glial cells. Toxicol.Lett. 149, $67-73$

75. Jammi, N. V., Whitby, L. R., Beal, P. A. (2003) Small molecule inhibitors of the RNA-dependent protein kinase. Biochem.Biophys.Res.Commun. 308, 50-57

76. Fagan, P. A., Spielmann, H. P., Sigurdsson, S., Rink, S. M., Hopkins, P. B., Wemmer, D. E. (1996) An NMR study of [d(CGCGAATTCGCG)]2 containing 
an interstrand cross-link derived from a distamycin-pyrrole conjugate. Nucleic Acids Res. 24, 1566-1573

77. Holz, B., Klimasauskas, S., Serva, S., Weinhold, E. (1998) 2-Aminopurine as a fluorescent probe for DNA base flipping by methyltransferases. Nucleic Acids Res. 26, 1076-1083

78. Bennett, R. L., Blalock, W. L., May, W. S. (2004) Serine 18 phosphorylation of RAX, the PKR activator, is required for PKR activation and consequent translation inhibition. J.Biol.Chem. 279, 42687-42693

79. Miller, M. W. (1996) Effect of early exposure to ethanol on the protein and DNA contents of specific brain regions in the rat. Brain Res. 734, 286-294

80. Lang, C. H., Wu, D., Frost, R. A., Jefferson, L. S., Vary, T. C., Kimball, S. R. (1999) Chronic alcohol feeding impairs hepatic translation initiation by modulating eIF2 and eIF4E. Am.J.Physiol 277, E805-E814

81. Lang, C. H., Frost, R. A., Kumar, V., Vary, T. C. (2000) Impaired myocardial protein synthesis induced by acute alcohol intoxication is associated with changes in eIF4F. Am.J.Physiol Endocrinol.Metab 279, E1029-E1038

82. Wu, J. M. (1981) Control of protein synthesis in rabbit reticulocytes. Inhibition of polypeptide synthesis by ethanol. J.Biol.Chem. 256, 4164-4167

83. Lang, C. H., Wu, D., Frost, R. A., Jefferson, L. S., Vary, T. C., Kimball, S. R. (1999) Chronic alcohol feeding impairs hepatic translation initiation by modulating eIF2 and eIF4E. Am.J.Physiol 277, E805-E814

84. Church, M. W., Gerkin, K. P. (1988) Hearing disorders in children with fetal alcohol syndrome: findings from case reports. Pediatrics 82, 147-154

85. Lang, C. H., Wu, D., Frost, R. A., Jefferson, L. S., Vary, T. C., Kimball, S. R. (1999) Chronic alcohol feeding impairs hepatic translation initiation by modulating eIF2 and eIF4E. Am.J.Physiol 277, E805-E814

86. Lang, C. H., Frost, R. A., Kumar, V., Vary, T. C. (2000) Impaired myocardial protein synthesis induced by acute alcohol intoxication is associated with changes in eIF4F. Am.J.Physiol Endocrinol.Metab 279, E1029-E1038

87. Lang, C. H., Frost, R. A., Deshpande, N., Kumar, V., Vary, T. C., Jefferson, L. S., Kimball, S. R. (2003) Alcohol impairs leucine-mediated phosphorylation of 4EBP1, S6K1, eIF4G, and mTOR in skeletal muscle. Am.J.Physiol Endocrinol.Metab 285, E1205-E1215

88. Wu, J. M. (1981) Control of protein synthesis in rabbit reticulocytes. Inhibition of polypeptide synthesis by ethanol. J.Biol.Chem. 256, 4164-4167 
89. Chen, J. J., London, I. M. (1995) Regulation of protein synthesis by hemeregulated eIF-2 alpha kinase. Trends Biochem.Sci. 20, 105-108

90. Clemens, M. J. (1997) PKR--a protein kinase regulated by double-stranded RNA. Int.J.Biochem.Cell Biol. 29, 945-949

91. Ito, T., Yang, M., May, W. S. (1999) RAX, a cellular activator for doublestranded RNA-dependent protein kinase during stress signaling. J.Biol.Chem. $274,15427-15432$

92. Wek, R. C. (1994) eIF-2 kinases: regulators of general and gene-specific translation initiation. Trends Biochem.Sci. 19, 491-496

93. Santoyo, J., Alcalde, J., Mendez, R., Pulido, D., de, H. C. (1997) Cloning and characterization of a cDNA encoding a protein synthesis initiation factor-2alpha (eIF-2alpha) kinase from Drosophila melanogaster. Homology To yeast GCN2 protein kinase. J.Biol.Chem. 272, 12544-12550

94. Berlanga, J. J., Santoyo, J., de, H. C. (1999) Characterization of a mammalian homolog of the GCN2 eukaryotic initiation factor 2alpha kinase. Eur.J.Biochem. $265,754-762$

95. Harding, H. P., Zhang, Y., Ron, D. (1999) Protein translation and folding are coupled by an endoplasmic-reticulum-resident kinase. Nature 397, 271-274

96. Pestova, T. V., Kolupaeva, V. G., Lomakin, I. B., Pilipenko, E. V., Shatsky, I. N., Agol, V. I., Hellen, C. U. (2001) Molecular mechanisms of translation initiation in eukaryotes. Proc.Natl.Acad.Sci.U.S.A 98, 7029-7036 1

97. Prostko, C. R., Brostrom, M. A., Brostrom, C. O. (1993) Reversible phosphorylation of eukaryotic initiation factor 2 alpha in response to endoplasmic reticular signaling. Mol.Cell Biochem. 127-128, 255-265

98. Scheper, G. C., van, W. R., Thomas, A. M. (2001) Regulation of the activity of eukaryotic initiation factors in stressed cells. Prog.Mol.Subcell.Biol. 27, 40-56

99. Tan, S. L., Katze, M. G. (1999) The emerging role of the interferon-induced PKR protein kinase as an apoptotic effector: a new face of death? J.Interferon Cytokine Res. 19, 543-554

100. Proud, C. G. (1995) PKR: a new name and new roles. Trends Biochem.Sci. 20, 241-246

101. Krichevsky, A. M., Metzer, E., Rosen, H. (1999) Translational control of specific genes during differentiation of HL-60 cells. J.Biol.Chem. 274, 14295-14305 
102. Lang, C. H., Wu, D., Frost, R. A., Jefferson, L. S., Vary, T. C., Kimball, S. R. (1999) Chronic alcohol feeding impairs hepatic translation initiation by modulating eIF2 and eIF4E. Am.J.Physiol 277, E805-E814

103. Patel, R. C., Sen, G. C. (1998) PACT, a protein activator of the interferon-induced protein kinase, PKR. EMBO J. 17, 4379-4390

104. Ruvolo, P. P., Gao, F., Blalock, W. L., Deng, X., May, W. S. (2001) Ceramide regulates protein synthesis by a novel mechanism involving the cellular PKR activator RAX. J.Biol.Chem. 276, 11754-11758

105. Bennett, R. L., Blalock, W. L., May, W. S. (2004) Serine 18 phosphorylation of RAX, the PKR activator, is required for PKR activation and consequent translation inhibition. J.Biol.Chem. 279, 42687-42693 


\section{Appendix: Detailed Method}

\section{Animals and ethanol exposure in vivo}

Long-Evans rats were obtained from Harlan-Sprague-Dawley (Indianapolis, IN). The animals were maintained in a temperature/humidity controlled facility in which the light/dark cycle was $12 \mathrm{~h} / 12 \mathrm{~h}$ and fed with protein-enriched diets that were nutritionally balanced and met the requirements of pregnant rats (Bio-Serv, Frenchtown NJ). Pups were anesthetized by injection of ketamine/xylazine and decapitated. Their cerebella were harvested by cutting through the cerebellar peduncles, frozen on dry ice, and stored at $-80^{\circ} \mathrm{C}$ for further processing.

\section{Immunoblots analysis}

Tissues or cells were washed with PBS and lysed with RIPA buffer for 10 minutes. Adherent cell fragments were scraped from the dish and the entire lysate was transferred to microfuge tubes. Solubilized cells were centrifuged, the proteinaceous supernatant was collected, and protein concentration was determined by Lowry assay (1). Aliquots of the supernatant were loaded onto the lanes of a sodium dodecylsulfate (SDS) 7.5 15.0\% polyacrylamide gel. Each aliquot contained $15 \sim 60 \mu \mathrm{g}$ of protein. The proteins were separated by electrophoresis, and the separated proteins were transferred to nitrocellulose membrane. The membranes were washed with $5.0 \%$ nonfat dry milk or Albumin from bovine serum (BSA) in $0.010 \mathrm{M}$ phosphate buffered saline (pH 7.4) and $0.10 \%$ Tween-20 (TPBS) at room temperature for one hour to block non-specific immunoreactivity. Subsequently, the membranes were incubated with primary antibodies

for $1 \frac{1}{2}$ hours at room temperature. After two quick washes in TPBS, the membranes 
were incubated with a secondary antibody diluted at 1:1,000 10,000 in TPBS for 1 hour. The immune complexes were detected with the enhanced chemiluminescence method (Amersham, Arlington Hts. IL). The blots were stripped and re-probed with an anti- actin antibody. Since ethanol does not affect the expression of actin, the variation in loading was normalized against the amount of actin expression in each lane. The relative amount of protein imaged on the films was quantified using a Sigma Gel program (Jandel, San Rafael, CA).

\section{Cerebellar granule cell culture and ethanol exposure in vitro}

Isolation and cultures of cerebellar granule neurons were created using a previously described method (2-5). Seven-day-old Sprague Dawley rat pups were decapitated and cerebella carefully removed. The brain tissue was minced with a sterile razor blade and suspended in $10 \mathrm{ml}$ of trypsine solution $(0.025 \%)$ at $37^{\circ} \mathrm{C}$. After incubation for $15 \mathrm{~min}$, an equal volume of a solution containing DNAse (130 Knuitz units $/ \mathrm{ml})$ and trypsine inhibitor $(0.75 \mathrm{mg} / \mathrm{ml})$ was added and the tissue was sedimented by a brief ( 5 seconds) centrifugation. The tissue was dissociated by trituration, and the cell suspension was centrifuged through a $4.0 \%$ bovine serum albumin solution, which is a critical step for increasing neuronal viability. The cell pellet was resuspended in Eagle's minimal essential medium containing the following supplements: $10.0 \%$ fetal bovine serum (FBS), $25 \mathrm{mM} \mathrm{KCL}, 1 \mathrm{mM}$ glutamine, $33 \mathrm{mM}$ glucose, and penicillin (100 units $/ \mathrm{ml}) /$ streptomycin $(100 \mu \mathrm{g} / \mathrm{ml})$. Cell numbers were determined with a hemocytometer. Cells were plated at certain densities into poly-D-lysine (PDL)-coated wells. Cells were incubated at $37^{\circ} \mathrm{C}$ in a humidified environment containing $5.0 \% \mathrm{CO}_{2}$ 
for at least 24 hours to permit cell adhesion before initiating further treatment. A method utilizing sealed containers (6-8) was used to maintain ethanol levels in the culture medium. With this method, ethanol was added directly to the culture medium in either tissue culture trays or dishes. Then, the trays or dishes were placed in sealed containers in which there was an ethanol-containing water bath in the bottom. The concentration of ethanol in the bath was the same as that in the culture medium. Ethanol from the bath evaporates into the air of the sealed container and maintains the ethanol concentration in the culture medium. A small volume of $\mathrm{CO}_{2}(60 \mathrm{ml})$ was injected into the container prior to sealing. The ethanol bath was changed daily to maintain the ethanol concentration. In control cultures, the water bath contains no ethanol. All containers were incubated at $37^{\circ} \mathrm{C}$. Previous studies have shown that this sealed container method accurately maintains ethanol concentrations in the culture medium (9).

\section{MTT assay}

MTT assay is based on the cleavage of the yellow tetrazolium salt MTT [3-(4,5dimethylthiazol-2yl)-2,5-diphenyl tetrazolium bromide] to purple formazan crystals by metabolically active cells (10). The MTT assay kit was purchased from Roche Molecular Biochemicals (Cat. \#: 1465 007, Indianapolis, IN). The cerebellar granule neurons were plated into 96-well microtiter plates at certain density with total volume of $100 \mu 1$. Cultures were then treated with either ethanol or kinases inhibitors. After treatment, ten microliters of MTT labeling reagent were added to each well and plates were incubated at $37^{\circ} \mathrm{C}$ for $4 \mathrm{~h}$. Following MTT incubation, the cultures were solubilized and the spetrophotometric absorbance of the samples was detected by a microtiter plate reader. 
The wavelength to measure absorbance of formazan product is $570 \mathrm{~nm}$ with a reference wavelength of $750 \mathrm{~nm}$.

\section{Immunoprecipitation}

Immunoprecipitates were generated with a previous described method (Luo and Miller, 1999). The cell lysate was collected, and an aliquot containing 200 300 $\mu \mathrm{g}$ of protein was incubated with antibody against the protein (1:50 in PBS) for overnight at $4^{\circ} \mathrm{C}$. Twenty microliters of Protein $\mathrm{A} / \mathrm{G}$ conjugated to argrose (Santa Cruz Biotech.) were added to the lysate, and the mixture was incubated 3 hours at $4^{\circ} \mathrm{C}$. Immunoprecipitates were collected by centrifugation at $10,000 \mathrm{x}$ g for $10 \mathrm{~min}$. The pellet was washed three times with $0.5 \mathrm{ml}$ RIPA buffer [150 mM NaCl, $50 \mathrm{mM}$ Tris (pH 8.0), $1.0 \%$ Nonidet P-40, $0.10 \%$ SDS, $0.50 \%$ deoxycholic acid sodium, $0.10 \mathrm{mg} / \mathrm{ml}$ phenylmethylsulfonyl fluoride, $1.0 \mathrm{mM}$ sodium orthovanadate, and $3.0 \%$ Aprotinin (Sigma)]. After the final wash, the supernatant was aspirated. The pellet was resuspended in $20 \mu \mathrm{l}$ of assay dilution buffer $(20 \mathrm{mM}$ MOPs, $\mathrm{pH} 7.2,25 \mathrm{mM}$ betaglycerol phosphate, $5 \mathrm{mM}$ EGTA, $1 \mathrm{mM}$ sodium orthovanadate, $1 \mathrm{mM}$ dithiothretol) and then analyzed it using the procedures described in inmmunoblts analysis.

\section{Culture of human neuroblastoma cells expressing inducible TrkB}

Human neuroblastoma SH-SY5Y cells expressing inducible TrkB (TB3 and TB8 cells) were generated under the control of a tetracycline (Tet)-repressible promoter element (11). Cells were cultured in RPMI 1640 containing 10.0\% FBS, $2.0 \mathrm{mM}$ glutamine and penicillin (100.0 units $/ \mathrm{ml}) /$ streptomycin $(100.0 \mu \mathrm{g} / \mathrm{ml})$. TB8 cells were 
maintained in a RPMI 1640 medium contained Tet $(1.0 \mu \mathrm{g} / \mathrm{ml}$; Tet-on condition). For induction of TrkB expression, cells were switched to a Tet-free medium (Tet-off condition) for further treatment.

\section{Apoptosis assay}

Accumulation of DNA fragments in the cytoplasm of apoptotic cells was determined by ELISA (Roche Molecular Biochemicals). We have demonstrated that this measurement was sensitive to quantify neuronal apoptosis and was consistent with other morphometric indices of apoptosis (12-14). Briefly, the cells were maintained in 96-well plates. After treatment, the cultures were washed twice with 0.01 M PBS, and the cultured cells were lysed. Twenty microliters of cell lysate from each well were mixed with $80 \mu \mathrm{l}$ of antibody solution in the coated wells. The loaded wells were incubated at room temperature for $2 \mathrm{~h}$. Substrate was added to each well after it was washed three times in incubation buffer. After incubation at room temperature for 10-20 min, the optical density was measured using a microtiter plate reader with a light filter of $405 \mathrm{~nm}$. The readings were used to measure the degree of apoptosis.

\section{Northern blot analysis}

Total RNA was extracted from TB3 and TB8 cells cultured in either Tet-on or Tet-off conditions. RNA isolation and hybridization were performed as described previously (15). Thirty $\mu \mathrm{g}$ of total RNA for TrkB was eletrophoresed in $1.2 \%$ agarose$6 \%$ formaldehyde gels. Gels were stained with $2 \mathrm{mg} / \mathrm{ml}$ ethidium bromide. 
Hybridization was performed with ${ }^{32} \mathrm{P}$-labeled insert DNA isolated from a plasmid containing TrkB (16).

\section{Protein synthesis assay}

Protein synthesis was measured by incorporation of ${ }^{14} \mathrm{C}$ labled amino acids (Amersham CFB104). Cells were seeded in 24-well cell culture trays at the density of $5 \times 10^{5}$ cells/well. After ethanol treatment for the indicated time, $2.5 \mu \mathrm{Ci}{ }^{14} \mathrm{C}$ amino acid mix was added to the wells, incubated at $37^{\circ} \mathrm{C}$ for 15 minutes and then medium was removed, cells were lysed with 1 vol. cold RIPA buffer. Reactions were stopped by the addition of 1 vol. Cold 20\% TCA. The acid insoluble fraction was collected on Whatman glass fiber filters (47mM GF/A) and radioactivity was measured by liquid scintillation counting.

10. Statistics analysis

Differences among treatment groups were tested using analysis of variance (ANOVA). Differences in which $p$ was less than 0.05 were considered statistically significant. In cases where significant differences were detected, specific post-hoc comparisons between treatment groups were examined with Student-Newman-Keuls tests. 


\section{Reference List}

1. Lowry, O. H., Rosebrough, N. J., Farr, A. L., Randall, R. J. (1951) Protein measurement with the Folin phenol reagent. J.Biol.Chem. 193, 265-275

2. Dutton, G. R., Barry, M., Simmons, M. L., Philibert, R. A. (1991) Astrocyte taurine. Ann.N.Y.Acad.Sci. 633, 489-500

3. Miyazawa, K., Himi, T., Garcia, V., Yamagishi, H., Sato, S., Ishizaki, Y. (2000) A role for $\mathrm{p} 27 / \mathrm{Kip} 1$ in the control of cerebellar granule cell precursor proliferation. J.Neurosci. 20, 5756-5763

4. Muller, Y., Duperray, C., Caruso, F., Clos, J. (1994) Autocrine regulation of proliferation of cerebellar granule neurons by nerve growth factor. J.Neurosci.Res. $38,41-55$

5. Tao, Y., Black, I. B., Cicco-Bloom, E. (1996) Neurogenesis in neonatal rat brain is regulated by peripheral injection of basic fibroblast growth factor (bFGF). J.Comp Neurol. 376, 653-663

6. Adickes, E. D., Mollner, T. J., Lockwood, S. K. (1988) Closed chamber system for delivery of ethanol to cell cultures. Alcohol Alcohol 23, 377-381

7. Luo, J., Miller, M. W. (1997) Differential sensitivity of human neuroblastoma cell lines to ethanol: correlations with their proliferative responses to mitogenic growth factors and expression of growth factor receptors. Alcohol Clin.Exp.Res. 21, 11861194

8. Pantazis, N. J., Dohrman, D. P., Luo, J., Goodlett, C. R., West, J. R. (1992) Alcohol reduces the number of pheochromocytoma (PC12) cells in culture. Alcohol 9, 171180

9. Luo, J., Miller, M. W. (1997) Differential sensitivity of human neuroblastoma cell lines to ethanol: correlations with their proliferative responses to mitogenic growth factors and expression of growth factor receptors. Alcohol Clin.Exp.Res. 21, 11861194

10. Vistica, D. T., Skehan, P., Scudiero, D., Monks, A., Pittman, A., Boyd, M. R. (1991) Tetrazolium-based assays for cellular viability: a critical examination of selected parameters affecting formazan production. Cancer Res. 51, 2515-2520

11. Jaboin, J., Kim, C. J., Kaplan, D. R., Thiele, C. J. (2002) Brain-derived neurotrophic factor activation of TrkB protects neuroblastoma cells from chemotherapy-induced apoptosis via phosphatidylinositol 3'-kinase pathway. Cancer Res. 62, 6756-6763 
12. Li, Z., Lin, H., Zhu, Y., Wang, M., Luo, J. (2001) Disruption of cell cycle kinetics and cyclin-dependent kinase system by ethanol in cultured cerebellar granule progenitors. Brain Res.Dev.Brain Res. 132, 47-58

13. Luo, J., Sun, Y., Lin, H., Qian, Y., Li, Z., Leonard, S. S., Huang, C., Shi, X. (2003) Activation of JNK by vanadate induces a Fas-associated death domain (FADD)dependent death of cerebellar granule progenitors in vitro. J.Biol.Chem. 278, 45424551

14. Chen, G., Bower, K. A., Ma, C., Fang, S., Thiele, C. J., Luo, J. (2004) Glycogen synthase kinase 3beta (GSK3beta) mediates 6-hydroxydopamine-induced neuronal death. FASEB J. 18, 1162-1164

15. Thiele, C. J., Cohen, P. S., Israel, M. A. (1988) Regulation of c-myb expression in human neuroblastoma cells during retinoic acid-induced differentiation. Mol.Cell Biol. 8, 1677-1683

16. Kim, S. O., Hasham, M. I., Katz, S., Pelech, S. L. (1998) Insulin-regulated protein kinases during postnatal development of rat heart. J.Cell Biochem. 71, 328-339 


\section{Curriculum Vitae}

\section{Gang Chen}

2096 HSN

Department of Microbiology, Immunology and Cell biology

1 Medical Center Drive

Morgantown, WV 26505

(304) 293-4624

gchen26505@yahoo.com

\section{EDUCATION}

Ph.D. Genetics and Developmental Biology Program

West Virginia University, Morgantown, WV, USA, 2005

M.S. Department of Biology

FuJian Teacher's University, FuZhou, FuJian, P.R. of China, 1988

B.S. Department of Biology

FuJian Teacher's University, FuZhou, FuJian, P.R. of China, 1985

\section{RESEARCH EXPERIENCE}

Research Scientist, FuZhou Fishery Research Institute, FuZhou, FuJian, P.R. of China 1988-2001.

\section{PUBLICATIONS}

Chen G. and Luo J. (2005) The mechanism of ethanol-induced protein synthesis inhibition in cerebellum granule cells. (in preparation).

Chen,G.; Bower,K.A.; Ma,C.; Fang,S.; Thiele,C.J.; Luo,J. (2003) Glycogen synthase kinase 3 beta (GSK3beta) mediates 6-hydroxydopamine-induced neuronal death. FASEB J 2004 Jul;18(10):1162-1164.

Ma,C.; Bower,K.A.; Lin,H.; Chen,G.; Huang,C.; Shi,X.; Luo,J. (2005) The role of epidermal growth factor receptor in ethanol-mediated inhibition of activator protein-1 transactivation. Biochem Pharmacol. 2005 Jun 15;69(12):1785-94. 